\title{
DOI/GTN-P Climate and Active-Layer Data Acquired in the National Petroleum Reserve-Alaska and the Arctic National Wildlife Refuge, 1998-2019
}

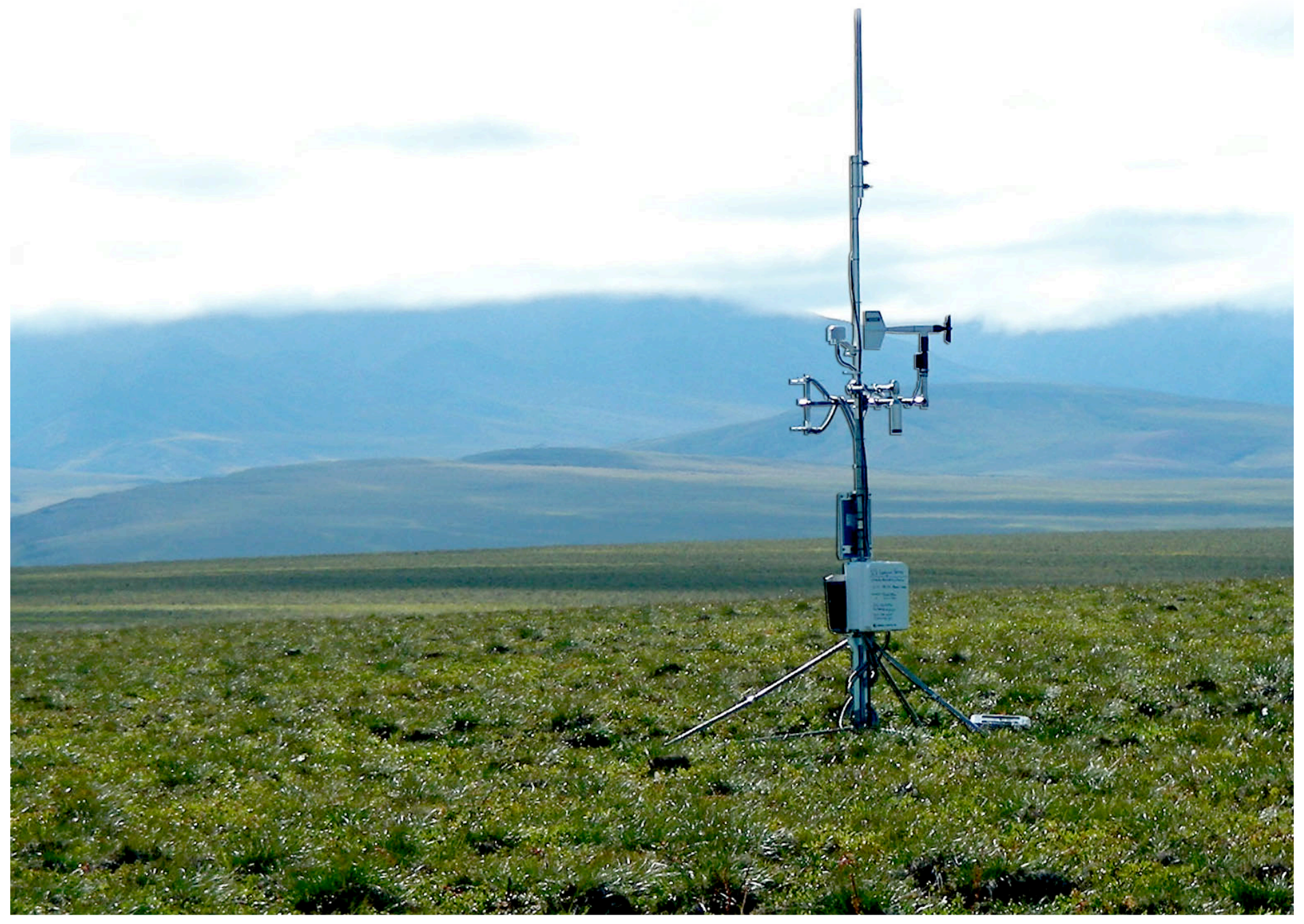

Data Series 1092

Version 1.2, June 2021 
Cover. U.S. Department of the Interior/Global Terrestrial Network for Permafrost (DOI/GTN-P) climate-monitoring station U31 at Marsh Creek, Arctic National Wildlife Refuge, Alaska. 


\section{DOI/GTN-P Climate and Active-Layer Data Acquired in the National Petroleum Reserve-Alaska and the Arctic National Wildlife Refuge, 1998-2019}

By Frank E. Urban and Gary D. Clow

Data Series 1092

Version 1.2, June 2021

Supersedes USGS Data Series 1021

U.S. Department of the Interior

U.S. Geological Survey 


\title{
U.S. Department of the Interior RYAN K. ZINKE, Secretary
}

\section{U.S. Geological Survey James F. Reilly II, Director}

\author{
U.S. Geological Survey, Reston, Virginia \\ First release: 2018 \\ Revised: June 2020 (ver. 1.1) \\ Revised: June 2021 (ver. 1.2) \\ Supersedes USGS Data Series 1021
}

\begin{abstract}
For more information on the USGS - the Federal source for science about the Earth, its natural and living resources, natural hazards, and the environment-visit https://www.usgs.gov or call 1-888-ASK-USGS.

For an overview of USGS information products, including maps, imagery, and publications, visit https://store.usgs.gov/.
\end{abstract}

\author{
Any use of trade, firm, or product names is for descriptive purposes only and does not imply endorsement by the \\ U.S. Government. \\ Although this information product, for the most part, is in the public domain, it also may contain copyrighted materials \\ as noted in the text. Permission to reproduce copyrighted items must be secured from the copyright owner. \\ Suggested citation: \\ Urban, F.E., and Clow, G.D., 2018, DOI/GTN-P climate and active-layer data acquired in the National Petroleum \\ Reserve-Alaska and the Arctic National Wildlife Refuge, 1998-2019 (ver. 1.2, June 2021), U.S. Geological Survey \\ Data Series 1092, 71 p., https://doi.org/10.3133/ds1092. [Supersedes USGS Data Series 1021.] \\ ISSN 2327-638X (online)
}

List of station data ScienceBase data release files and summary tables for this report are available at https://doi.org/10.5066/F7VXOFGB. 


\section{Acknowledgments}

The authors thank and acknowledge all the staff of the Bureau of Land Management (BLM) Arctic Field Office and the U.S. Fish and Wild life Service (FWS) Fairbanks Field Office whose steady logistical and scientific support has made this ongoing effort possible. In particular, we thank Don Meares, Richard Kemnitz, Shane Walker, Eric Yeager, Connie Adkins, Lon Kelly, Stacie McIntosh, Donna Wixon, and Matthew Whitman at the BLM and Janet Jorgenson, David Payer, Stephen Arthur, and Paul Leonard at the FWS. Specific thanks to Jeremy Havens (USGS) for help with manuscript preparation and online publishing. Development of the DOI/GTN-P Observing Network was supported by the U.S. Geological Survey Global Change and Climate History Program (now the Climate and Land Use Change Research and Development Program).

\section{Contents}

Acknowledgments …..............................................................................................................

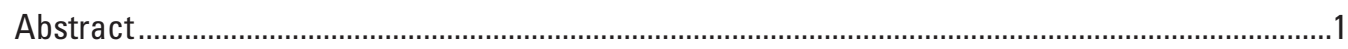

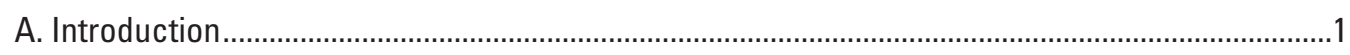

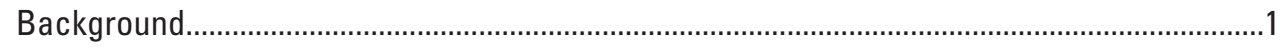

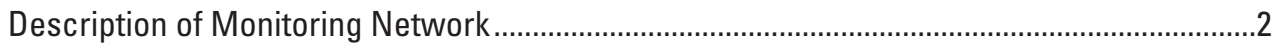

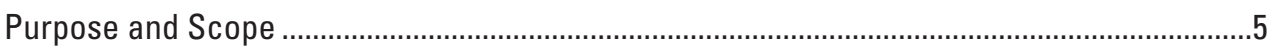

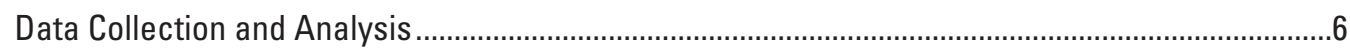

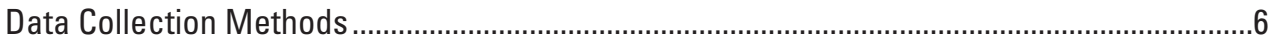

Data Processing and Quality Control ................................................................................

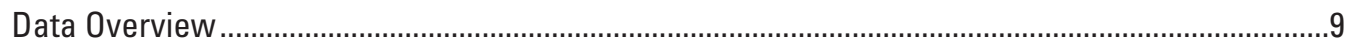

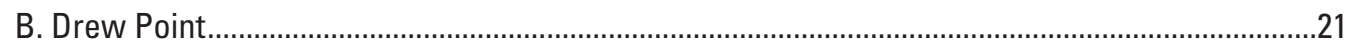

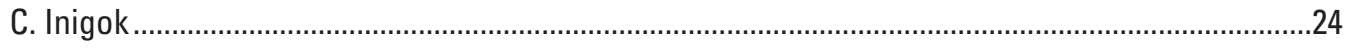

D. Fish Creek

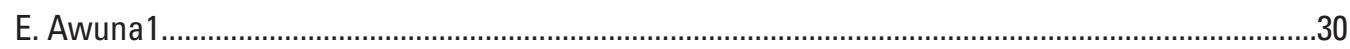

F. Umiat

G. Tunalik

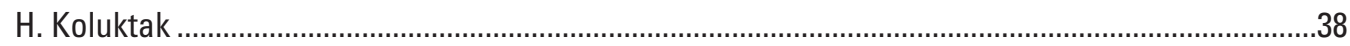

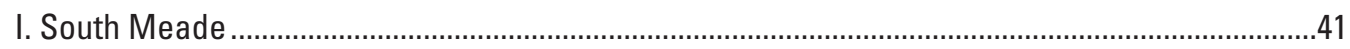

J. Awuna2

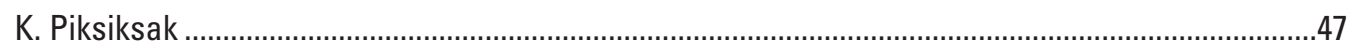

L. East Teshekpuk

M. Ikpikpuk

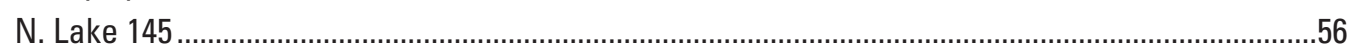

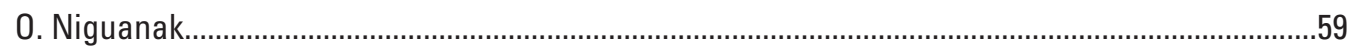

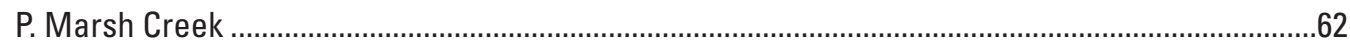

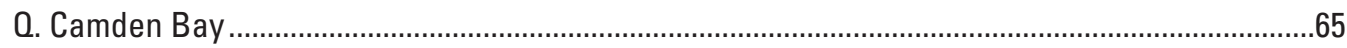

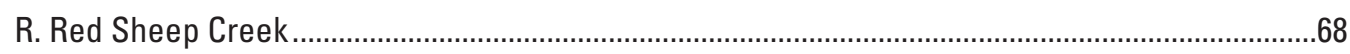

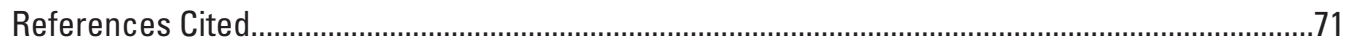




\section{Figures}

A-1. U.S. Department of the Interior/Global Terrestrial Network for Permafrost (DOI/GTN-P) climate monitoring array in Arctic Alaska . .2

A-2. Components of a typical U.S. Department of the Interior/Global Terrestrial Network for Permafrost (DOI/GTN-P) climate monitoring station

A-3. Sample air temperature record from Fish Creek station .................................................11

A-4. Sample wind speed record from Fish Creek station......................................................12

A-5. Sample windroses from Fish Creek station.................................................................13

A-6. Sample ground temperature record from Fish Creek station .........................................14

A-7. Sample incident solar-flux record from Fish Creek station ................................................15

A-8. Sample reflected solar-flux record from Fish Creek station .............................................16

A-9. Sample rainfall record from Inigok station......................................................................

A-10. Sample snow depth record from Inigok station ..............................................................18

A-11. Sample soil moisture record at 15-centimeter depth from Inigok station ........................19

A-12. Sample surface pressure record from Fish Creek station..............................................20

B-1. Location map presenting the specific location of the Drew Point site and its spatial relation to other sites in the monitoring network ...........................................................21

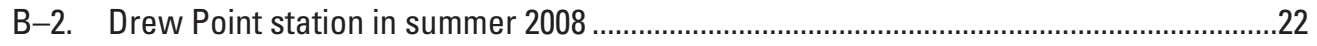

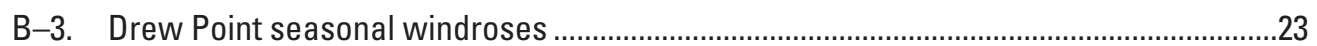

C-1. Location map presenting the specific location of the Inigok site and its spatial

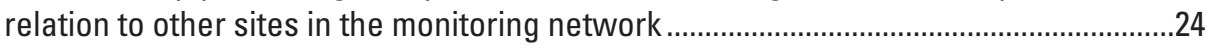

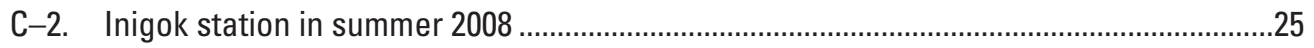

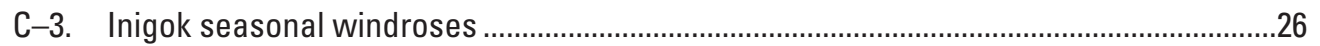

D-1. Location map presenting the specific location of the Fish Creek site and its spatial relationship to other sites in the monitoring network....................................................

D-2. Fish Creek station in summer 2008......................................................................28

D-3. Fish Creek seasonal windroses.........................................................................29

E-1. Location map presenting the specific location of the Awuna1 site and its spatial relation to other sites in the monitoring network ...............................................................30

E-2. Awuna1 station in summer 2008 ............................................................................31

F-1. Location map presenting the specific location of the Umiat site and its spatial relation to other sites in the monitoring network .............................................................32

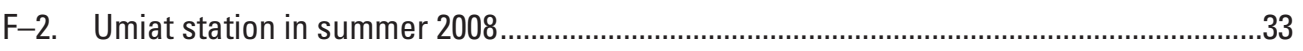

F-3. Umiat seasonal windroses .....................................................................................34

G-1. Location map presenting the specific location of the Tunalik site and its spatial

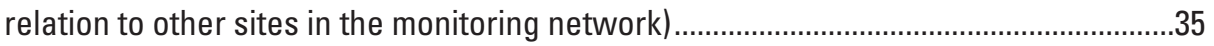

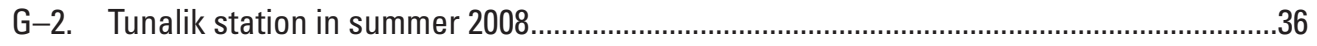

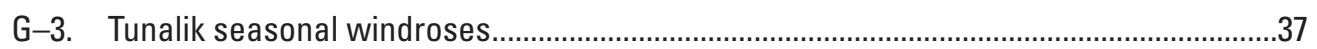

$\mathrm{H}-1$. Location map presenting the specific location of the Koluktak site and its spatial relation to other sites in the monitoring network ..............................................................38

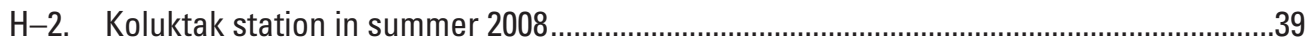

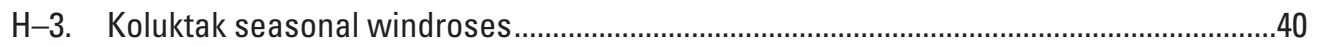

I-1. Location map presenting the specific location of the South Meade site and its spatial relation to other sites in the monitoring network .................................................41

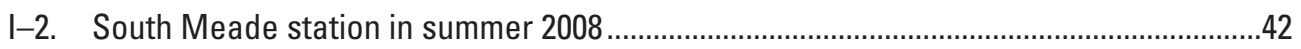

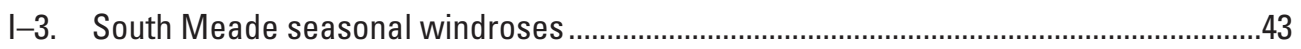


J-1. Location map presenting the specific location of the Awuna2 site and its spatial relation to other sites in the monitoring network ..........................................................4

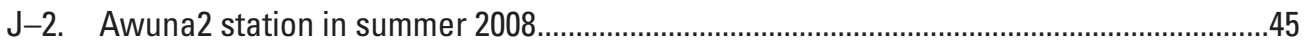

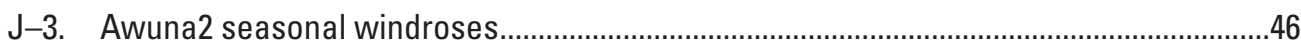

K-1. Location map presenting the specific location of the Piksiksak site and its spatial relation to other sites in the monitoring network ..........................................................

K-2. Piksiksak station in summer 2008 ..........................................................................

K-3. Piksiksak seasonal windroses................................................................................4

L-1. Location map presenting the specific location of the East Teshekpuk site and its spatial relation to other sites in the monitoring network ..................................................50

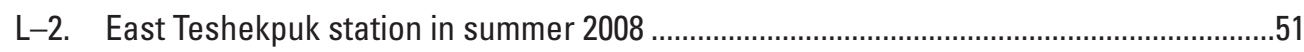

L-3. East Teshekpuk seasonal windroses ....................................................................52

M-1. Location map presenting the specific location of the Ikpikpuk site and its spatial relation to other sites in the monitoring network ...........................................................53

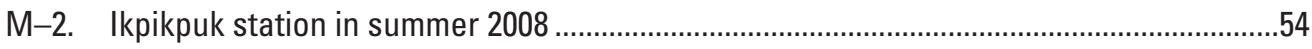

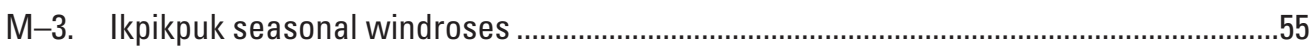

$\mathrm{N}-1$. Location map presenting the specific location of the Lake 145 site and its spatial relation to other sites in the monitoring network ……...................................................56

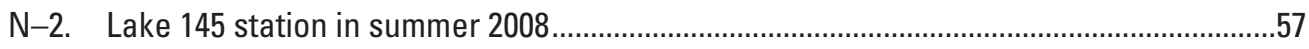

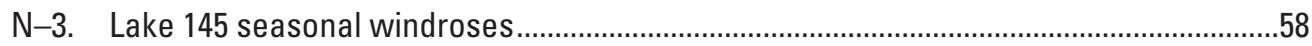

0-1. Location map presenting the specific location of the Niguanak site and its spatial relation to other sites in the monitoring network ..........................................................59

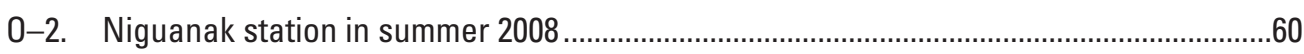

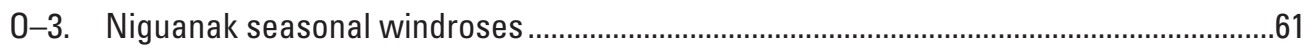

P-1. Location map presenting the specific location of the Marsh Creek site and its spatial relation to other sites in the monitoring network .................................................62

P-2. Marsh Creek station in summer 2008 .....................................................................63

P-3. Marsh Creek seasonal windroses ..............................................................................64

Q-1. Location map presenting the specific location of the Camden Bay site and its spatial relation to other sites in the monitoring network ....................................................65

0-2. Camden Bay station in summer 2008......................................................................66

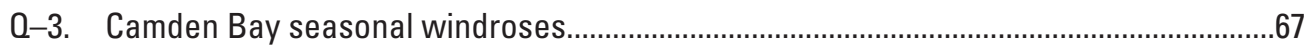

R-1. Location map presenting the specific location of the Red Sheep Creek site and its spatial relation to other sites in the monitoring network ..................................................68

R-2. Red Sheep Creek station in summer 2008 .................................................................69

R-3. Red Sheep Creek seasonal windroses ....................................................................

\section{Tables}

A-1. Location, elevation, and installation dates for the U.S. Department of the Interior/Global Terrestrial Network for Permafrost (DOI/GTN-P) climate monitoring stations....

A-2. Full metadata information for each sensor at each station, including install date and presence or absence of sensor. 


\section{Conversion Factors}

SI to Inch/Pound

\begin{tabular}{lcl}
\hline \multicolumn{1}{c}{ Multiply } & By & \multicolumn{1}{c}{ To obtain } \\
\hline centimeter $(\mathrm{cm})$ & Length & \\
meter $(\mathrm{m})$ & 0.3937 & inch $(\mathrm{in})$. \\
kilometer $(\mathrm{km})$ & 3.281 & foot $(\mathrm{ft})$ \\
& 0.6214 & mile $(\mathrm{mi})$ \\
\hline square kilometer $\left(\mathrm{km}^{2}\right)$ & Area & Acre \\
square kilometer $\left(\mathrm{km}^{2}\right)$ & 247.1 & square mile $\left(\mathrm{mi}^{2}\right)$ \\
\hline & 0.3861 & \\
\hline meter per second $(\mathrm{m} / \mathrm{s})$ & Speed & foot per second $(\mathrm{ft} / \mathrm{s})$ \\
\hline
\end{tabular}

Temperature in degrees Celsius $\left({ }^{\circ} \mathrm{C}\right)$ may be converted to degrees Fahrenheit $\left({ }^{\circ} \mathrm{F}\right)$ as follows:

$$
{ }^{\circ} \mathrm{F}=\left(1.8 \times{ }^{\circ} \mathrm{C}\right)+32
$$

Temperature degrees in Celsius $\left({ }^{\circ} \mathrm{C}\right)$ may be converted to degrees Kelvin $\left({ }^{\circ} \mathrm{K}\right)$ as follows:

$$
{ }^{\circ} \mathrm{K}={ }^{\circ} \mathrm{C}+273.15
$$

Vertical coordinate information is referenced to the World Geodetic System 1984 (WGS 84).

\section{Abbreviations}
CSI Campbell Scientific
DOI U.S. Department of the Interior
GTN-P Global Terrestrial Network for Permafrost
MRC Measurement Research Corporation
USGS U.S. Geological Survey 


\title{
DOI/GTN-P Climate and Active-Layer Data Acquired in the National Petroleum Reserve-Alaska and the Arctic National Wildlife Refuge, 1998-2019
}

\author{
By Frank E. Urban and Gary D. Clow
}

\begin{abstract}
This report provides data collected by the climate monitoring array of the U.S. Department of the Interior on Federal lands in Arctic Alaska over the period August 1998 to July 2019; this array is part of the Global Terrestrial Network for Permafrost (DOI/GTN-P). In addition to presenting data, this report also describes monitoring, data collection, and qualitycontrol methods. The array of 16 monitoring stations spans lat $68.5^{\circ} \mathrm{N}$. to $70.5^{\circ} \mathrm{N}$. and long $142.5^{\circ} \mathrm{W}$. to $161^{\circ} \mathrm{W}$., an area of approximately 150,000 square kilometers. Climate summaries are presented along with quality-controlled data. Data collection is ongoing and includes the following climate- and permafrost-related variables: air temperature, wind speed and direction, ground temperature, soil moisture, snow depth, rainfall totals, up- and downwelling shortwave radiation, and atmospheric pressure. These data were collected by the U.S. Geological Survey in close collaboration with the Bureau of Land Management and the U.S. Fish and Wildlife Service.
\end{abstract}

\section{A. Introduction}

\section{Background}

Atmosphere-ocean general circulation models consistently project that the largest climate changes during this century will occur in the Arctic, especially in Arctic Alaska and the adjacent Bering, Beaufort, and Chukchi Seas - that is, lands and portions of the seas managed by the U.S. Department of the Interior (DOI) (Houghton and others, 2001; Arctic Council, 2005; Chapman and Walsh, 2007; Walsh, 2008). Every aspect of the Alaskan Arctic environment is expected to be significantly affected over the next few decades, posing tremendous land management challenges for DOI (DeGange and others, 2005; Clow and others, 2011). This region is particularly vulnerable to climate change because of the prevalence of ice-rich permafrost, which is projected to degrade significantly during this century (U.S. Arctic Research Commission, 2003; Lawrence and others, 2008). In Arctic Alaska, permafrost is the foundation upon which terrestrial ecosystems and human infrastructure exist. The indigenous plants and wildlife of this region are highly adapted to extreme conditions, and large projected climate changes are expected to stress these specialized biological systems.

Accurate data detailing current environmental conditions and rates of environmental change on DOI lands in Arctic Alaska $^{1}$ are critical to fulfill the DOI mission. This is particularly true given the high rates of change that are now occurring in the region (Jeffries and others, 2012). Because of the remoteness and harsh environmental conditions in the Arctic and northern Alaska, the observational database of climate-change-related variables for the region has been extremely limited. The paucity of baseline environmental data contributes to the uncertainty in future climate projections and climate impact assessments in a number of ways:

- Insufficient knowledge of many of the physical processes active in this region makes correctly representing them in climate models difficult (National Research Council, 2001; Arctic Council, 2005).

- Without adequate information about current conditions, it is difficult to assess whether the models are performing correctly (model validation).

- High-quality data to supply the boundary conditions necessary for climate-model runs are lacking, particularly at the higher spatial resolutions needed for making land-management decisions.

Studies by the National Research Council $(2001,2010)$ have concluded there is a pressing need for a comprehensive system designed for monitoring climate, particularly in the Arctic, if we are to reduce the uncertainties in future climate projections and the associated climate impacts.

\footnotetext{
${ }^{1}$ The Bureau of Land Management, the U.S. Fish and Wildlife Service, and the Bureau of Ocean Energy Management all have significant management responsibilities for natural resources, wildlife, and the environment in this region.
} 


\section{Description of Monitoring Network}

To satisfy DOI's need for accurate environmental information and to improve future climate impact assessments, the U.S. Geological Survey (USGS) has established an array of climate-monitoring stations on Federal lands in Arctic Alaska as part of the U.S. Department of the Interior/Global Terrestrial Network for Permafrost (DOI/GTN-P) Observing System. This array currently consists of 16 automated stations (fig. A-1) spanning the National Petroleum Reserve-Alaska and the Arctic National Wildlife Refuge. The first stations were installed during August 1998, allowing for more than 21 years of high-quality observational data from some locations (table A-1). Additional stations in the array were gradually added with the goals of broader spatial and elevation coverage across a range of geomorphic substrates and vegetation regimes. Aspects of the physical environment monitored by these stations include shallow permafrost temperature at 10 depths (from 5 to 120 centimeters [cm]), active-layer thaw depth and duration, soil moisture, air temperature and pressure, wind speed and direction, up- and downwelling shortwave radiation, surface albedo, snow depth and duration, and rainfall (fig. A-2). The DOI/GTN-P climate monitoring array is an integral part (through data contribution) of a number of global observing systems, including the Global Terrestrial Network for Permafrost, the Global Terrestrial Observing System (GTOS), and the Global Climate Observing System (GCOS). On a regional scale, the stations also contribute to the Circumpolar Active-Layer Monitoring Network (CALM) and the Arctic Observing Network (AON).

$160^{\circ}$

$155^{\circ}$

$150^{\circ}$

$145^{\circ}$

$140^{\circ}$

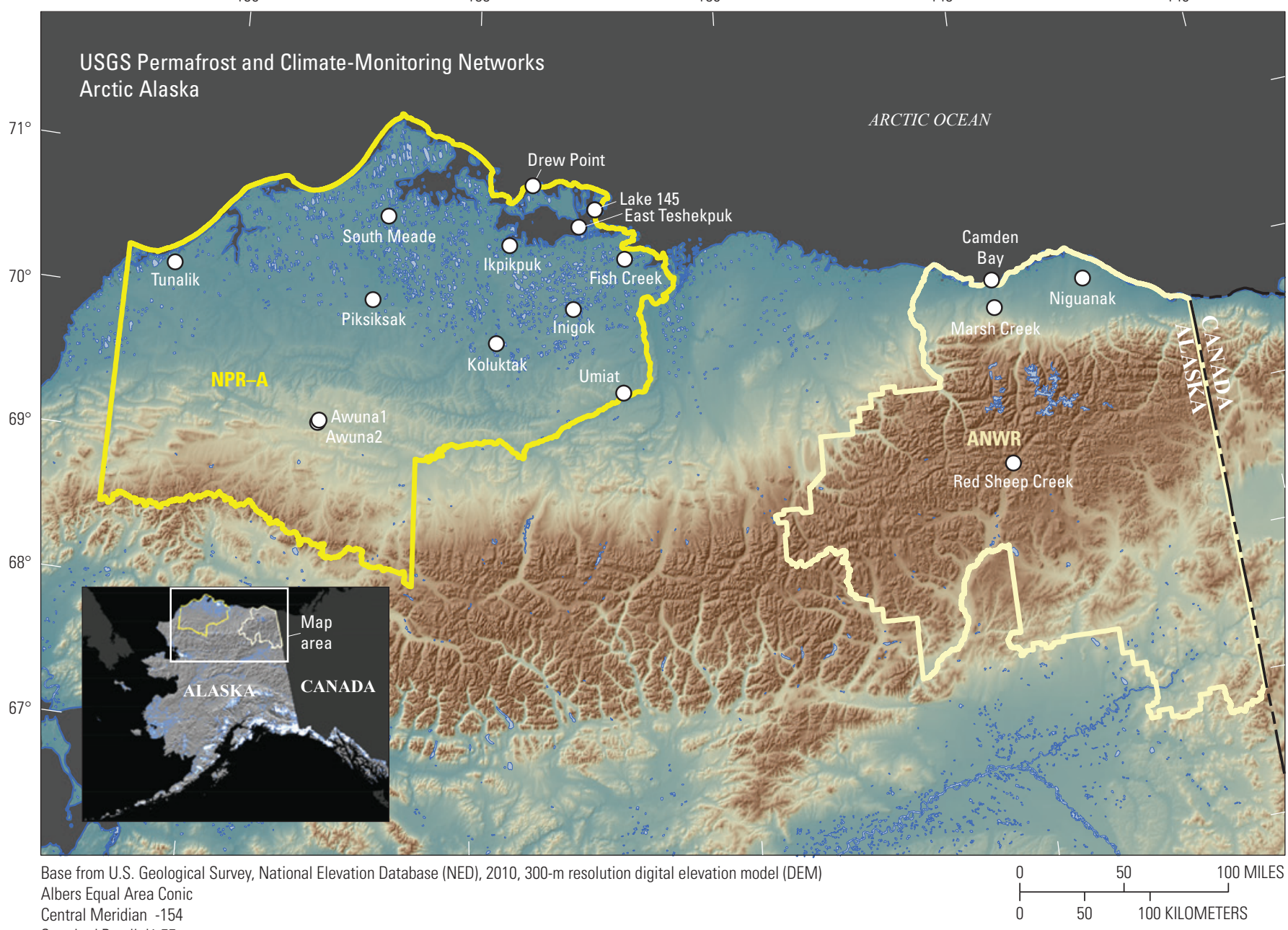

Central Meridian -154

Figure A-1. U.S. Department of the Interior/Global Terrestrial Network for Permafrost (DOI/GTN-P) climate monitoring array in Arctic Alaska. There are 12 stations currently operating in the National Petroleum Reserve-Alaska (NPR-A) and 4 stations in the Arctic National Wildlife Refuge (ANWR). 
Table A-1. Location, elevation, and installation dates for the U.S. Department of the Interior/Global Terrestrial Network for Permafrost (DOI/GTN-P) climate monitoring stations. Thirteen stations in the National Petroleum Reserve-Alaska are listed first, followed by four stations in the Arctic National Wildlife Refuge.

[AUG, August; m, meter]

\begin{tabular}{|c|c|c|c|c|c|}
\hline $\begin{array}{c}\text { Station } \\
\text { name }\end{array}$ & $\begin{array}{c}\text { GTN-P } \\
\text { code }\end{array}$ & $\begin{array}{c}\text { Station } \\
\text { installation } \\
\text { date }\end{array}$ & Latitude & Longitude & $\begin{array}{c}\text { Elevation } \\
(\mathrm{m})\end{array}$ \\
\hline Drew Point & U20 & 18 AUG 1998 & $70^{\circ} 51.872^{\prime} \mathrm{N}$ & $153^{\circ} 54.405^{\prime} \mathrm{W}$. & 5 \\
\hline Fish Creek & U22 & 18 AUG 1998 & $70^{\circ} 20.114^{\prime} \mathrm{N}$ & $152^{\circ} 03.120^{\prime} \mathrm{W}$. & 31 \\
\hline Awuna $1^{1}$ & $\mathrm{U} 23$ & 19 AUG 1998 & $69^{\circ} 10.226^{\prime} \mathrm{N}$ & $158^{\circ} 00.402^{\prime} \mathrm{W}$. & 362 \\
\hline Koluktak & U30 & 27 AUG 1999 & $69^{\circ} 45.096^{\prime} \mathrm{N}$ & $154^{\circ} 37.054^{\prime} \mathrm{W}$. & 60 \\
\hline South Meade & U33 & 08 AUG 2003 & $70^{\circ} 37.708^{\prime} \mathrm{N}$ & $156^{\circ} 50.119^{\prime} \mathrm{W}$. & 15 \\
\hline Awuna2 & U35 & 22 AUG 2003 & $69^{\circ} 09.331^{\prime} \mathrm{N}$ & $158^{\circ} 01.827^{\prime} \mathrm{W}$. & 343 \\
\hline Piksiksak & U37 & 08 AUG 2004 & $70^{\circ} 02.197^{\prime} \mathrm{N}$ & $157^{\circ} 04.882^{\prime} \mathrm{W}$. & 33 \\
\hline Marsh Creek & U31 & 03 AUG 2001 & $69^{\circ} 46.657^{\prime} \mathrm{N}$ & $144^{\circ} 47.595^{\prime} \mathrm{W}$. & 260 \\
\hline Camden Bay & U34 & 14 AUG 2003 & $69^{\circ} 58.317^{\prime} \mathrm{N}$ & $144^{\circ} 46.234^{\prime} \mathrm{W}$. & 4 \\
\hline Red Sheep Creek & U36 & 03 AUG 2004 & $68^{\circ} 40.898^{\prime} \mathrm{N}$ & $144^{\circ} 50.524^{\prime} \mathrm{W}$. & 785 \\
\hline
\end{tabular}

${ }^{1}$ Awuna1 was decommissioned on 22 May 2004. It was replaced by Awuna2, located 1.91 kilometers to the southwest. The two stations ran concurrently for several months.

${ }^{2}$ Lake 145 has not yet been assigned a GTN-P code. 


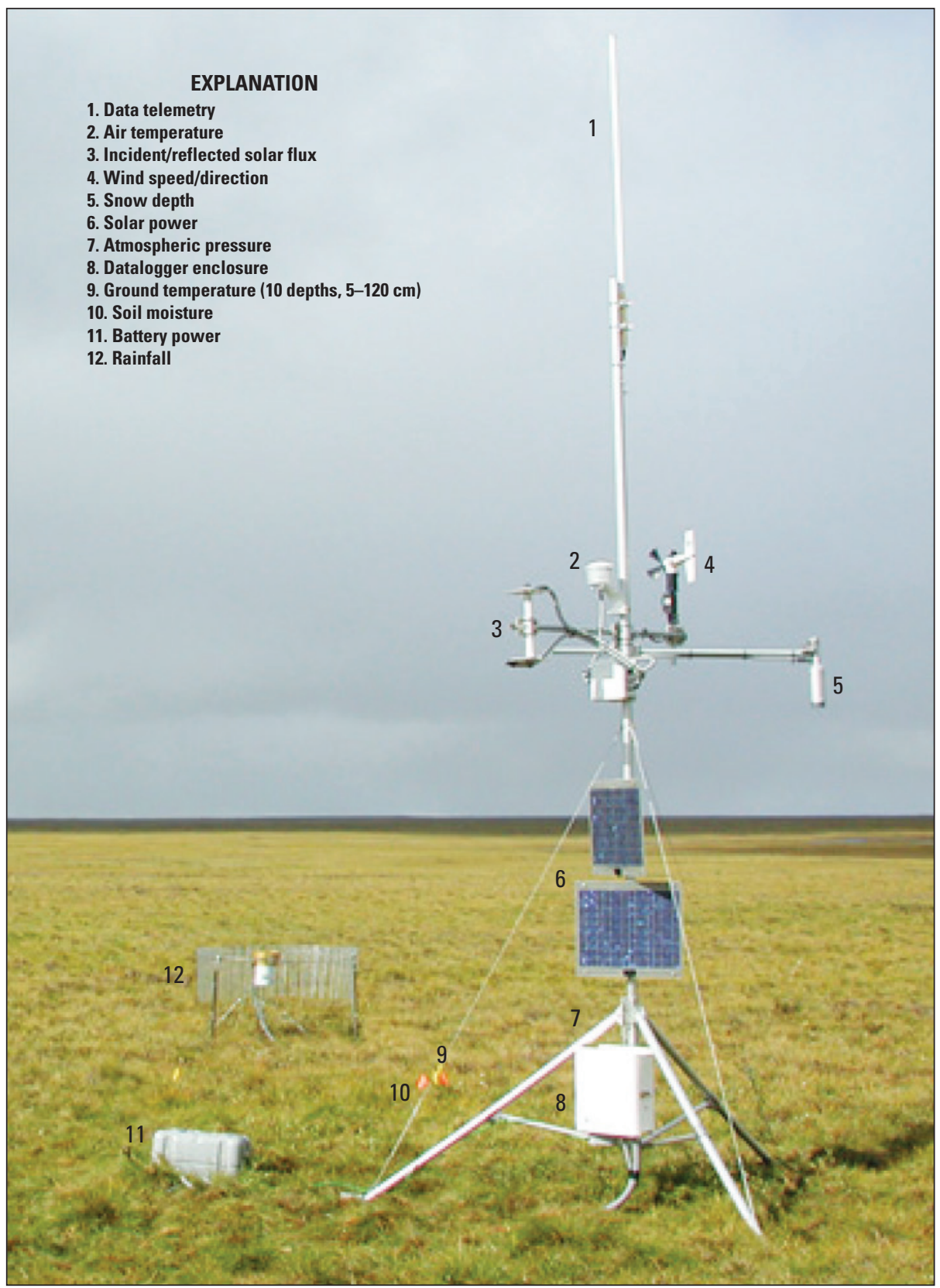

Figure A-2. Components of a typical U.S. Department of the Interior/Global Terrestrial Network for Permafrost (DOI/GTN-P) climate monitoring station. (cm, centimeter). 


\section{Purpose and Scope}

Historically, very little climate information has been collected on Federal lands in Arctic Alaska. The information that has been collected generally resulted from short-term campaigns designed to support oil development and other activities. This report provides data collected by the DOI/GTN-P climate monitoring array over the period August 1998 through July 2019 that greatly augment the existing record for this region. Variables presented in this report include ground temperature at 10 depths $(5-120 \mathrm{~cm})$, soil moisture, air temperature and pressure, wind speed and direction, incident and reflected solar flux, snow depth, and rainfall. Because the network took nearly a decade to develop (table A-1), the records are of varying lengths. For example, the longest air and ground temperature and snow depth records cover nearly 21 years (as of July 2019), whereas the longest wind and soil moisture records cover about 15 years (table A-2). Although short, the records are long enough to establish climate gradients and patterns across the region, quantify the magnitude of variability on daily through annual timescales, and provide the context for future climate change. Data collection is ongoing. Subsequent reports will provide annual updates and information on the full suite of climate variables monitored by the network.

Table A-2. Full metadata information for each sensor at each station, including install date and presence or absence of sensor.

[GTN-P, Global Terrestrial Network for Permafrost; APR, April; AUG, August; m, meter; cm, centimeter; agl, above ground level; yr, year; doy, day of year; hr, hour]

\begin{tabular}{|c|c|c|c|c|c|c|}
\hline $\begin{array}{c}\text { Station } \\
\text { name }\end{array}$ & $\begin{array}{l}\text { GTN-P } \\
\text { code }\end{array}$ & $\begin{array}{l}\text { Install } \\
\text { date }\end{array}$ & Latitude & Longitude & $\begin{array}{l}\text { Elevation } \\
\text { (m) }\end{array}$ & $\begin{array}{l}\text { Ground temperature depths } \\
\qquad(\mathrm{cm})\end{array}$ \\
\hline Drew Point & U20 & 18 AUG 1998 & $70^{\circ} 51.872^{\prime} \mathrm{N}$ & $153^{\circ} 54.405^{\prime} \mathrm{W}$. & 5 & $5,10,15,20,25,30,45,70,95,120$ \\
\hline Inigok & $\mathrm{U} 21$ & 17 AUG 1998 & $69^{\circ} 59.377^{\prime} \mathrm{N}$ & $153^{\circ} 05.630^{\prime} \mathrm{W}$. & 53 & $5,10,15,20,25,30,45,70,95,120$ \\
\hline Awunal (inactive) & $\mathrm{U} 23$ & 19 AUG 1998 & $69^{\circ} 10.226^{\prime} \mathrm{N}$ & $158^{\circ} 00.402^{\prime} \mathrm{W}$. & 362 & $5,10,15,20,25,30,45,70,95,120$ \\
\hline Umiat & $\mathrm{U} 24$ & 20 AUG 1998 & $69^{\circ} 23.741^{\prime} \mathrm{N}$ & $152^{\circ} 08.568^{\prime} \mathrm{W}$ & 201 & $5,10,15,20,25,30,45,70,95,120$ \\
\hline South Meade & U33 & 08 AUG 2003 & $70^{\circ} 37.708^{\prime} \mathrm{N}$ & $156^{\circ} 50.119^{\prime} \mathrm{W}$ & 15 & $5,10,15,20,25,30,45,70,95,120$ \\
\hline Awuna2 & $\mathrm{U} 35$ & 22 AUG 2003 & $69^{\circ} 09.3311^{\prime} \mathrm{N}$ & $158^{\circ} 01.827^{\prime} \mathrm{W}$. & 343 & $5,10,15,20,25,30,45,70,95,120$ \\
\hline Piksiksak & U37 & 08 AUG 2004 & $70^{\circ} 02.197 ' \mathrm{~N}$ & $157^{\circ} 04.882^{\prime} \mathrm{W}$. & 33 & $5,10,15,20,25,30,45,70,95,120$ \\
\hline East Teshekpuk & $\mathrm{U} 38$ & 10 AUG 2004 & $70^{\circ} 34.111^{\prime} \mathrm{N}$ & $152^{\circ} 57.899^{\prime} \mathrm{W}$ & 7 & $5,10,15,20,25,30,45,70,95,120$ \\
\hline Ikpikpuk & U39 & 21 AUG 2005 & $70^{\circ} 26.499^{\prime} \mathrm{N}$ & $154^{\circ} 21.938^{\prime} \mathrm{W}$. & 5 & $5,10,15,20,25,30,45,70,95,120$ \\
\hline Camden Bay & U34 & 14 AUG 2003 & $69^{\circ} 58.317^{\prime} \mathrm{N}$ & $144^{\circ} 46.234^{\prime} \mathrm{W}$. & 4 & $5,10,15,20,25,30,45,70,95,120$ \\
\hline Red Sheep Creek & U36 & 03 AUG 2004 & $68^{\circ} 40.898^{\prime} \mathrm{N}$ & $144^{\circ} 50.524^{\prime} \mathrm{W}$ & 785 & $5,10,15,20,25,30,45,70,95,120$ \\
\hline
\end{tabular}

\begin{tabular}{lccccc}
\hline \multicolumn{1}{c}{$\begin{array}{c}\text { Station } \\
\text { name }\end{array}$} & \multicolumn{1}{c}{ Ground } & Sir temperature & Sensor start date (yr, doy, hr) & Wind speed \\
temperature & (3 m agl) & Wind direction & $\begin{array}{c}\text { Incoming } \\
\text { radiation }\end{array}$ \\
\hline Drew Point & $1998,230,1600$ & $1998,230,1600$ & $2004,220,2000$ & $2004,220,2000$ & $2000,228,1800$ \\
Inigok & $1998,229,1400$ & $1998,229,1400$ & $2004,230,1800$ & $2004,230,1800$ & $1999,236,1400$ \\
Fish Creek & $1998,230,1200$ & $1998,230,1200$ & $2003,223,1600$ & $2003,223,1600$ & $1999,236,1800$ \\
Awunal (inactive) & $1998,231,1400$ & $1998,231,1400$ & - & - & $2000,229,1400$ \\
Umiat & $1998,232,2000$ & $1998,232,2000$ & $2005,109,1800$ & $2005,109,1800$ & $1999,236,1200$ \\
Tunalik & $1998,232,1600$ & $1998,232,1600$ & $2003,232,1600$ & $2003,232,1600$ & $1999,238,1400$ \\
Koluktak & $1999,239,1400$ & $1999,239,1400$ & $2004,223,1900$ & $2004,223,1900$ & $2000,230,1800$ \\
South Meade & $2003,220,1700$ & $2003,220,1700$ & $2003,220,1700$ & $2003,220,1700$ & $2003,220,1700$ \\
Awuna2 & $2003,236,1300$ & $2003,236,1300$ & $2003,236,1300$ & $2003,236,1300$ & $2003,236,1300$ \\
Piksiksak & $2004,221,1700$ & $2004,221,1700$ & $2005,217,1300$ & $2005,217,1300$ & $2004,221,1700$ \\
East Teshekpuk & $2004,223,1600$ & $2004,223,1600$ & $2005,218,1200$ & $2005,218,1200$ & $2004,223,1600$ \\
Ikpikpuk & $2005,233,2100$ & $2005,233,2100$ & $2005,233,2100$ & $2005,233,2100$ & $2005,233,2100$ \\
Lake 145 & $2007,225,1800$ & $2007,225,1800$ & $2007,225,1800$ & $2007,225,1800$ & $2007,225,1800$ \\
Niguanak & $2000,231,1600$ & $2000,231,1600$ & $2004,218,2200$ & $2004,218,2200$ & $2000,231,1600$ \\
Marsh Creek & $2001,215,1600$ & $2001,215,1600$ & $2003,225,1800$ & $2003,225,1800$ & $2001,215,1600$ \\
Camden Bay & $2003,226,1700$ & $2003,226,1700$ & $2007,217,1700$ & $2007,217,1700$ & $2003,226,1700$ \\
Red Sheep Creek & $2004,216,2200$ & $2004,216,2200$ & $2004,216,2200$ & $2004,216,2200$ & $2004,216,2200$
\end{tabular}


Table A-2. Full metadata information for each sensor at each station, including install date and presence or absence of sensor.-Continued

[GTN-P, Global Terrestrial Network for Permafrost; APR; April; AUG, August; m, meter; cm, centimeter; agl, above ground level; yr, year; doy, day of year; hr, hour]

\begin{tabular}{|c|c|c|c|c|c|}
\hline \multirow{2}{*}{$\begin{array}{l}\text { Station } \\
\text { name }\end{array}$} & \multicolumn{5}{|c|}{ Sensor start date (yr, doy, hr) } \\
\hline & $\begin{array}{l}\text { Reflected } \\
\text { radiation }\end{array}$ & $\begin{array}{l}\text { Snow } \\
\text { depth }\end{array}$ & $\begin{array}{l}\text { Soil moisture } \\
15-20 \mathrm{~cm}\end{array}$ & $\begin{array}{l}\text { Precipitation } \\
\text { (summer only) }\end{array}$ & $\begin{array}{c}\text { Atmospheric } \\
\text { pressure }\end{array}$ \\
\hline Inigok & $1998,229,1400$ & $1998,229,1400$ & $2003,222,1600$ & $2005,230,1300$ & - \\
\hline Fish Creek & $1998,230,1200$ & $1998,230,1200$ & $2003,223,1600$ & $2006,234,1100$ & $2006,234,1100$ \\
\hline Awunal (inactive) & $1998,231,1400$ & $2000,229,1400$ & - & - & - \\
\hline Tunalik & $1998,232,1600$ & $1999,238,1400$ & $2003,232,1600$ & $2009,218,1800$ & $2007,205,1600$ \\
\hline Koluktak & $1999,239,1400$ & $1999,239,1400$ & $2003,217,1600$ & $2012,216,1200$ & - \\
\hline South Meade & $2003,220,1700$ & $2003,220,1700$ & $2003,220,1700$ & $2007,214,1800$ & - \\
\hline Awuna2 & $2003,236,1300$ & $2003,236,1300$ & $2003,236,1300$ & - & $2008,216,1500$ \\
\hline Piksiksak & $2004,221,1700$ & $2004,221,1700$ & $2004,221,1700$ & $2014,220,1000$ & - \\
\hline Niguanak & $2000,231,1600$ & $2000,231,1600$ & $2003,225,2000$ & $2013,209,1700$ & $2010,210,0700$ \\
\hline Marsh Creek & $2001,215,1600$ & $2001,215,1600$ & $2003,225,1800$ & $2010,211,2300$ & $2007,116,0100$ \\
\hline Camden Bay & $2003,226,1700$ & $2003,226,1700$ & $2003,226,1700$ & - & - \\
\hline Red Sheep Creek & $2004,216,2200$ & $2004,216,2200$ & $2004,216,2200$ & - & - \\
\hline
\end{tabular}

\section{Data Collection and Analysis}

\section{Data Collection Methods}

Each station consists of a solar- and battery-powered datalogger (Campbell Scientific [CSI] model CR10X or CR1000, depending on the station), a sensor mast, and the sensors (fig. A-2). Air temperature, wind, radiation, and rainfall values are sampled every 30 seconds and then averaged once per hour (rainfall is totaled). Ground temperatures, soil moisture, snow depth, and surface pressure values are sampled once per hour. The resultant data stream from this sampling protocol is of hourly resolution. Because of limited power and data storage capacity, measurements taken before August 2003 were stored once every 2 hours rather than hourly. Physical site visits are made 1-2 times per year to collect the stored measurements and to carry out station maintenance. All stations utilize spread spectrum radio or iridium telemetry capabilities and data are occasionally downloaded between site visits.

The air temperature measurements are made using a CSI model 107 thermistor probe mounted in a naturally aspirated six-gill radiation shield located 3 meters $(\mathrm{m})$ above the surface as measured during the snow-free period. The CSI model 107 probe is sampled using a half-bridge voltage measurement. To reduce measurement uncertainties, voltages are converted to temperature during the data processing step using a four-term calibration function appropriate for the full temperature range experienced at these sites $\left(-50^{\circ} \mathrm{C}\right.$ to $\left.+30^{\circ} \mathrm{C}\right)$.
Wind speed and direction are measured using a R.M. Young 05103 wind monitor, located $3 \mathrm{~m}$ above the surface. For wind direction, the hourly vector mean is stored, although prior to April 2008, the arithmetic mean was stored rather than the vector mean.

Ground temperature is measured once per hour at ten depths using a Measurement Research Corporation (MRC) TP101 model temperature probe. The probe is $125 \mathrm{~cm}$ long and contains 10 thermistors at depths of 5, 10, 15, 20, 25, 30, $45,70,95$, and $120 \mathrm{~cm}$. The MRC thermistors are read on a single-ended channel through an interface circuit containing a half-bridge network and a means to switch the excitation voltage to each thermistor. A fixed precision resistor within the MRC is sampled at each time-step for comparison and to improve the estimate of the measurement voltages. Resistance is calculated from the voltage measurements and then converted to temperature using a four-term calibration function similar to the Steinhart-Hart equation (Steinhart and Hart, 1968) but with an additional term that improves the calibration fit below $0{ }^{\circ} \mathrm{C}$.

Incident and reflected solar-flux measurements are made with CSI model LI200X silicon pyranometers located $3 \mathrm{~m}$ above the surface. The pyranometers are measured using a differential voltage measurement. A factory standard-calibration factor is applied to the resultant voltages to produce energyflux values.

Rainfall is measured with a Texas Electronics TE525 rain gage mounted approximately $60 \mathrm{~cm}$ above the ground in the 
middle of an ETI Instrument Systems Lexan altershield. The sensor is sampled every 30 seconds and millimeter $(\mathrm{mm})$ totals are stored once per hour.

Snow depth is measured once per hour with a CSI model SR50 ultrasonic distance sensor mounted approximately $2.5 \mathrm{~m}$ above the ground surface. The sensor sends out an ultrasonic pulse and measures the time it takes for the signal to bounce off the ground or snow surface and return to the sensor. The travel time of the ultrasonic pulse varies with temperature; this effect is taken into account using data from the CSI model 107 air temperature sensor. The distance to the ground calculated from the ultrasonic travel time is subtracted from the known distance, as measured during physical site visits and distancedata analysis, to calculate snow depth.

Soil moisture is measured once per hour at approximately 15-cm depth using a Stevens Hydra Probe Soil Moisture sensor. Four single-ended voltage measurements are stored by the datalogger and then converted to soil moisture and salinity using algorithms supplied by the manufacturer.

Atmospheric pressure is measured once per hour through a vented port in the datalogger enclosure using a Vaisala PTB101B barometer.

\section{Data Processing and Quality Control}

Because of the harsh operating environment, a variety of problems can affect the sensors and resulting data streams. These include loss of system power, total or partial failure of the sensor-support mast due to bear activity, damage or destruction of sensor cables or the sensors themselves by wildlife, obstruction of air temperature radiation shields by snow or rime ice, complete freeze-up of wind sensors by rime ice, obstruction of incident solar-flux detectors by snow, corrosion of snow depth transducers by high humidity, false snow depth signals caused by blowing snow, intermittent electrical noise associated with electric bear fences, vertical movement ("jacking") of ground temperature sensors by freeze-thaw forces, and others.

A multi-component data-processing system has been developed to automatically and consistently handle a number of the data processing tasks, including application of sensor calibration factors, masking data during periods that are known to be problematic, masking data that are outside reasonable predefined limits, calculation of derived climate variables (for example, thawing-degree days, maximum activelayer depth, and total precipitation), calculation of climate statistics on a variety of timescales (hourly to decadal), and calculation of climate trends and anomalies. Predefined faulty data limits are unique to each sensor and are based on known environmental extremes and sensor specific performance. For example, hourly average wind speed values are flagged for masking if they are less than zero (physically impossible) or if they exceed 40 meters per second $(\mathrm{m} / \mathrm{s})$, a condition that is highly unlikely. The system also includes a number of tools to assist the data technician in identifying spurious data that are missed by the automated routines and require a higher level of analysis. For example, wind speed values are automatically flagged if they do not change for 6 consecutive hours, likely indicating a condition of sensor freeze-up during icing. The technician is notified of these periods and directed to investigate each freeze-up period individually for any additional masking that may be necessary. First, the processing system is applied on a station- and sensor-specific basis. Second, the system is used in interstation mode, whereby statistics are calculated for data from the one or two most spatially proximate stations, depending on data availability and environmental homogeneity. Time periods that contain data that exceed statistical limits are further scrutinized and masked where appropriate. After the release of USGS Data Series 812, 892, and 977 (Urban and Clow, 2014a, b, 2016), small improvements were made to the data processing system in order to release a more complete data series. In the previous releases, all calculated averages were based on hourly resolution data. In this report, averages at resolutions greater than daily are calculated from daily average values. Details of the data processing system and the raw data files are available as a USGS data release in ScienceBase at https://doi.org/10.5066/F7VX0FGB.

Air temperature.-The resistance $R s$ of a CSI model 107 air temperature sensor is determined from the stored halfbridge voltage $V$ using the equation

$$
R s=R f\left(\frac{V x}{V}-1\right)-R b
$$

where $R f$ and $R b$ are the resistances of the field and bridge resistors in the half-bridge, respectively, and $V x$ is the excitation voltage. The excitation voltage can vary slightly, so it is collected each time a measurement is made. Temperature is then calculated from the measured resistance using the fourterm calibration function

$$
T^{-1}=a_{0}+a_{1}(\ln R s)+a_{2}(1 \mathrm{n} R s)^{2}+a_{3}(\ln R s)^{3}
$$

where $T$ is temperature expressed in Kelvin.

This is an extension of the often used Steinhart-Hart equation (Steinhart and Hart, 1968), which proved inadequate for our purposes below $0{ }^{\circ} \mathrm{C}$. The four calibration coefficients $\left(a_{0}, a_{1}, a_{2}, a_{3}\right)$ are determined for each CSI model 107 probe by monitoring its resistance while the temperature is varied from $-50{ }^{\circ} \mathrm{C}$ to $+30{ }^{\circ} \mathrm{C}$ in a Hart Scientific temperature calibration bath at the USGS temperature calibration facility in Boulder, Colorado. For those rare instances where $a_{0}, a_{1}, a_{2}$, and $a_{3}$ are unavailable for a particular CSI model 107 sensor, we use values that have been determined for a "factory standard" probe.

Temperature measurements are assigned a bad data code when it is determined they do not represent the air temperature field $3 \mathrm{~m}$ above the ground. Data that have been assigned such a code are effectively masked and are not used in any further calculations (for example, climate statistics, climate trends, or climate anomalies). Beyond the general problems described above (for example, insufficient system power and change in sensor height due to 
sensor mast damage), specific problems that can lead to air temperature masking include (a) reduction of the necessary ventilation through the radiation shield by snow, rime ice, or low wind speeds $(<1 \mathrm{~m} / \mathrm{s})$, and (b) the sensor falling out of the radiation shield, exposing it to solar radiational heating. Air temperature climate statistics are calculated when the data are available at least 95 percent of the time.

Wind speed and direction.-No calibration factors or corrections are currently applied to the wind speed or wind direction measurements. Specific problems that can lead to masking of either the wind speed or wind direction include significant ice buildup that prevents the wind monitor from functioning properly. In some cases, icing will affect the wind speed measurements but not the wind direction, and vice versa. The threshold for calculating climate statistics for the wind variables is the same as for air temperature, that is, 95 percent data availability.

Ground temperatures.-The resistances of the MRC TP101 thermistors are determined from the stored half-bridge voltages using known values for the excitation voltage and the circuit's fixed resistors. The thermistor resistances are then converted to temperature using the same four-term calibration function (eq. 2) as for the air temperature sensor. In this case, the four calibration coefficients $\left(a_{0}, a_{1}, a_{2}, a_{3}\right)$ were determined from data for a "factory standard" MRC probe over the temperature range $-40{ }^{\circ} \mathrm{C}$ to $+10^{\circ} \mathrm{C}$. The stated uncertainty of the MRC measurements is $0.1^{\circ} \mathrm{C}$. To further reduce the uncertainty of the ground temperature measurements, a special set of orthonormal basis functions were fit to site specific zero-curtain ground temperature profiles in a least-squares sense where the number of basis functions retained was determined by the reduced chi-squared values. The difference between the zero-curtain temperature profiles (based on the factory standard calibration) and the resulting least-squares fit provided an estimate of the unique calibration offset for each thermistor relative to the factory standard. These calibration offsets were then applied as corrections to the data. With these corrections, the standard uncertainty of the ground temperature measurements is believed be in the range $0.02-0.05^{\circ} \mathrm{C}$. Small improvements from previously released USGS Data Series 812 and 892 (Urban and Clow, 2014a, b) have been made to the data processing system such that the resulting ground temperatures are more complete and more accurate. The improvements are as follows, and details of the refined data processing algorithms are described in "DOI/GTN-P Climate-Station Data, Quality Assurance and Control Procedures" included in the USGS data release in ScienceBase (Urban, 2017) at https://doi.org/10.5066/F7VX0FGB. No new improvements have been added since the updates in 2017.

Each data logger has a unique internal voltage offset that affects the half-bridge voltage measurements used to determine the resistance of each thermistor. The resistances are now corrected for this offset, eliminating a small shift that occurred when data loggers were upgraded at each station. The excitation voltage used to drive the MRC probe is on occasion erroneously recorded even though the actual voltage was valid. Previously, when this occurred, the processing system masked the associated ground temperatures out of the data stream. Improved algorithms now allow recovery of the actual excitation voltages during these times; thus, ground temperatures can be reported when they were previously masked.

Beyond the general system problems (power loss, sensor or sensor cable damage, and so forth) that can lead to masking, the ground temperature instrument is subject to freeze-thaw processes inherent to its placement in permafrost. The MRC is a rigid instrument (the thermistors are encased in a hard epoxy potting in a long cylindrical shape), and permafrost and freeze-thaw processes periodically act to "jack" the instrument vertically out of its original position. The amount of jacking varies widely year to year and among stations. Many sites underwent no jacking, some sustained small $(1-3 \mathrm{~cm})$ documented amounts, and several sustained extreme $(5-10 \mathrm{~cm})$ amounts. The data processing system is used to mask data from the topmost thermistors at the 5- and sometimes $10-\mathrm{cm}$ depths when their values during unfrozen time periods exceed local air temperatures. These criteria indicate that portions of the instrument are exposed to solar radiation above the tundra and that those thermistors are reporting values that are erroneously warm. Stations with extreme jacking amounts during some portion of their deployment include Marsh Creek, Camden Bay, Ikpikpuk, Piksiksak, and Awuna1. The threshold for calculating climate statistics for ground temperatures is 95 percent data availability.

Incident and reflected solar flux.-The pyranometers that measure incoming and reflected shortwave radiation have a factory standard calibration factor applied to the raw measurements. Other than that, no corrections or calibrations are applied. Specific problems that can lead to masking of solar-flux values include significant ice or snow buildup, which prevent the sensor from functioning properly. This is generally much more of a problem for the downwelling (incident) radiation sensor than for the reflected flux sensor. Much of the radiation-data masking that is accomplished in the processing system is achieved by calculating ideal clear-sky radiation values at a given station location and then using differences between the calculated and observed values to identify times with potentially faulty data. The threshold for calculating climate statistics for incoming and reflected radiation is 95 percent data availability.

Rainfall.-Rainfall data are collected only during the summer months when air temperatures are above $0{ }^{\circ} \mathrm{C}$. A conversion factor is applied for each rainfall gage to convert the measured values (tipping bucket counts) into total millimeters per hour. In the late summer and autumn, rain may be mixed with snow; these periods are difficult to identify and mask in the data. The data processing system is employed to mask any rainfall data that occur (a) when there is snow on the ground, (b) in midwinter during isolated events when air temperature is above freezing, causing any snow in the rain gage to melt and provide faulty rain gage readings, and (c) in midspring during snowmelt when snow in the rain gage bucket melts and creates faulty readings. The threshold for calculating climate statistics for rainfall is 95 percent data availability. 
Snow depth.-Snow depth data are collected year round, and snow presence is confirmed by high-reflected solar-flux values. The distance to ground provided by the sensor during snow-free periods is included in the complete data files and can be utilized to some degree to investigate plant growth, foliar loss of tundra plants, and so forth. Negative values for snow depth are occasionally reported during snow-free periods and represent a deviation from what is determined as a local zero-depth value. Negative values are typically a result of changes in tundra surface characteristics, such as loss of leaves or grasses being matted down by wind and moisture. The snow depth sensor can return faulty values during periods of high wind and blowing snow. To detect this situation, the data processing system automatically flags snow depth values that are more than 3 standard deviations away from the running mean. The system color-codes the flagged (potentially bad) values according to wind speed to help determine whether masking is warranted. The high-wind flagged values are then masked along with those that occur during general system problems (for example, low power, damaged mast, and cable failure). The threshold for calculating climate statistics for snow depth is 90 percent data availability.

Soil moisture.-Factory standard conversion algorithms are applied to the raw data from the soil moisture sensor. Specific problems that can lead to masking of the soil moisture values include ground temperatures below $-15^{\circ} \mathrm{C}$, at which point the sensor behaves erratically. Three-sigma statistics are calculated for soil moisture data, and values that exceed these limits are masked. The threshold for calculating climate statistics for soil moisture is 95 percent data availability.

Atmospheric pressure.-No calibration factors or corrections are currently applied to the atmospheric pressure measurements. Beyond the general system problems that can lead to masking, there are no specific problems related to this sensor. Three-sigma statistics are calculated for atmospheric pressure data, and values that exceed these limits are masked. The threshold for calculating climate statistics for atmospheric pressure is 95 percent data availability.

\section{Data Overview}

Figures A-3 through A-12 present overviews of each of the data variables at several temporal scales. Figure A-3 shows the air temperature record from the Fish Creek monitoring station (lat $70^{\circ} 20.114^{\prime} \mathrm{N}$., long $152^{\circ} 03.120^{\prime} \mathrm{W}$.) at hourly resolution. The top panel shows the full record, the middle panel shows a single year of data, and the lower panels show 1 week of winter data and 1 week of summer data. The annual seasonal cycle is clearly evident in the top panel with minimum winter air temperatures dropping to about $-45^{\circ} \mathrm{C}$ and maximum summer temperatures reaching $+25^{\circ} \mathrm{C}$. In addition to the seasonal cycle, temperature excursions due to passing weather systems are discernible in the middle panel. These weather systems are the dominant source of air temperature variability during the winter (lower left panel). During the summer, air temperature variations are primarily related to changes in the incident solar radiation, which produces a strong diurnal cycle (lower right panel).

Figure A-4 shows the wind speed record from Fish Creek at hourly resolution. The top panel shows the full record, whereas the middle panel shows 1 full year, and the lower panels show 1 week of winter data and 1 week of summer data. Seasonal patterns are evident with the strongest wind events occurring during winter and the most consistent wind speeds occurring during the summer. The strongest winds, which are related to passing weather systems, are about $20 \mathrm{~m} / \mathrm{s}$ at this site. Occasional gaps in the sub $-0{ }^{\circ} \mathrm{C}$ portion of the record (upper and middle panels) are due to significant ice buildup on the wind monitor; the data have been masked during these periods. As with air temperature, passing weather systems are the dominant source of wind speed variability during the winter (lower left panel). A diurnal signal is apparent in the summer wind speed variability (lower right panel).

Figure A-5 shows windroses at the Fish Creek station for each of the four seasons: winter (December, January, February), spring (March, April, May), summer (June, July, August), and autumn (September, October, November). Windroses are useful for showing how both wind speeds and directions are distributed at a particular site. For the DOI/GTN-P dataset, windroses are calculated by dividing the wind direction into 16 categories $\left(22.5^{\circ}\right.$ each $)$ and the wind speed into three classes: (a) less than $5 \mathrm{~m} / \mathrm{s}$, (b) between $5 \mathrm{~m} / \mathrm{s}$ and $10 \mathrm{~m} / \mathrm{s}$, and (c) greater than $10 \mathrm{~m} / \mathrm{s}$. The windroses show that winds at Fish Creek most frequently come out of the east and east-northeast. The strongest winds occur during the winter and tend to come out of the east with a secondary maximum out of the west. Strong winds also occur during the transition seasons, autumn and spring, again primarily coming out of the east with a secondary maximum out of the west.

Figure A-6 shows the ground temperature record from the Fish Creek monitoring station at hourly resolution. The top panel shows the full record, the middle panel shows a single year of data, and the lower panels show 1 week of winter data and 1 week of summer data. The annual seasonal cycle is clearly evident in the top panel with minimum winter ground temperatures near the surface $(5 \mathrm{~cm})$ dropping to about $-20{ }^{\circ} \mathrm{C}$ and $-15^{\circ} \mathrm{C}$ at depth $(120 \mathrm{~cm})$. Maximum summer temperatures near the surface $(5 \mathrm{~cm})$ reach $+10{ }^{\circ} \mathrm{C}$ and $-2{ }^{\circ} \mathrm{C}$ at depth $(120 \mathrm{~cm})$. In the middle panel, seasonal changes are clearly evident with fast warming in the spring when snow melts and the low-albedo tundra surface is able to absorb shortwave radiation. In the autumn, the water-saturated soils take a long time to freeze solid due to the release of latent heat. In addition to the seasonal cycle, temperature excursions due to passing weather systems are discernible in the middle panel. These weather systems, as well as variability in snow cover, are the dominant source of ground temperature variability during the winter (lower left panel). During the summer, ground temperature variations in the active layer $(0-25 \mathrm{~cm}$ at Fish Creek) are primarily related to changes in the incident solar flux, which produces a strong diurnal cycle (lower right panel). Ground 
temperatures below the active layer in summer are reflective of longer term (annual) conditions including air temperature and previous winter snow cover.

Figure A-7 shows the incident solar flux from the Fish Creek monitoring station at hourly resolution. The top panel shows the full record; the bottom panel shows a single year of data. The annual seasonal cycle is clearly evident with maximum flux values in midsummer of about 600 to 700 watts per square meter with near 24 hours of daylight and values that drop to zero for about 2 months of winter when there is little or no daylight at this latitude. Cloudy periods are often evident in the peak summer months (June, July, and August) when temperatures are above freezing and sea ice in the adjacent ocean is far offshore, providing a consistent moisture source for cloud formation.

Figure A-8 shows the reflected shortwave radiation flux from the Fish Creek monitoring station at hourly resolution. The top panel shows the full record; the bottom panel shows a single year of data. The annual seasonal cycle is clearly evident with maximum flux values in midspring of about 600 watts per square meter and values that drop to zero for about 2 months of winter. A distinguishing feature of the reflected solar-flux data is the extremely rapid decrease in values during snowpack disintegration. This transition from snow cover to bare tundra usually occurs in late May or early June, and in the span of 5-7 days reflected solar-flux values drop from 600 to 150 watts per square meter.

Figure A-9 shows the entire accumulated rainfall record from the Inigok monitoring station (lat $69^{\circ} 59.377^{\prime} \mathrm{N}$., long $153^{\circ} 05.630^{\prime} \mathrm{W}$.) at four different resolutions: seasonal (top left panel), monthly (top right panel), weekly (bottom left panel), and daily (bottom right panel). The rainfall season typically begins in early June and ends in late September to early October, with the greatest rainfall amounts occurring in August.

Figure A-10 shows the snow depth record from the Inigok monitoring station. The top panel shows the full record at hourly resolution; the bottom panel shows a single year of data at daily resolution. The annual seasonal cycle is evident with snow accumulation typically beginning in late September to early October and snowmelt occurring in late May to early June. The snowpack gradually increases through the autumn (October-November), sometimes plateauing in the winter (January-March). Common snowpack features include midwinter wind scour (evident in the lower panel in late January), and early spring (April-May) snow depth increases immediately prior to snowmelt. A consistent aspect of the snowpack in this region is the extremely rapid disintegration that occurs in late May or early June. Once snowmelt ensues, the entire snowpack is usually gone in 7-10 days. Snow depth varies from station to station with a general trend of increasing depths away from the coast as elevation increases from the coast towards the Brooks Range (5-785 m).

Figure A-11 shows the hourly resolution soil moisture record at $15-\mathrm{cm}$ depth from the Inigok (lat $69^{\circ} 59.377^{\prime} \mathrm{N}$., long $153^{\circ} 05.630^{\prime} \mathrm{W}$.) monitoring station. Data gaps in winter occur when the ground temperature falls below about $-15^{\circ} \mathrm{C}$ and the sensor does not report valid values. The top panel shows the full record, the bottom panel shows a single year of data, and the inset shows soil-moisture-response details during one summer season. Typical water-fraction values are about 0.4 when the active layer is thawed and near zero when the active layer is frozen. The inset displays a common feature, higher initial water fraction in the soils after snowmelt that gradually dissipates, usually by the end of July. Rains in August and September are often reflected in temporary increases in the water fraction.

Figure A-12 shows the surface pressure record from the Fish Creek monitoring station at hourly resolution. The top panel shows the full record; the bottom panel shows a single year of data. A seasonal cycle is evident with fewer high-amplitude pressure changes in spring and summer (late March through mid-October) than in the autumn and winter (November through February). 

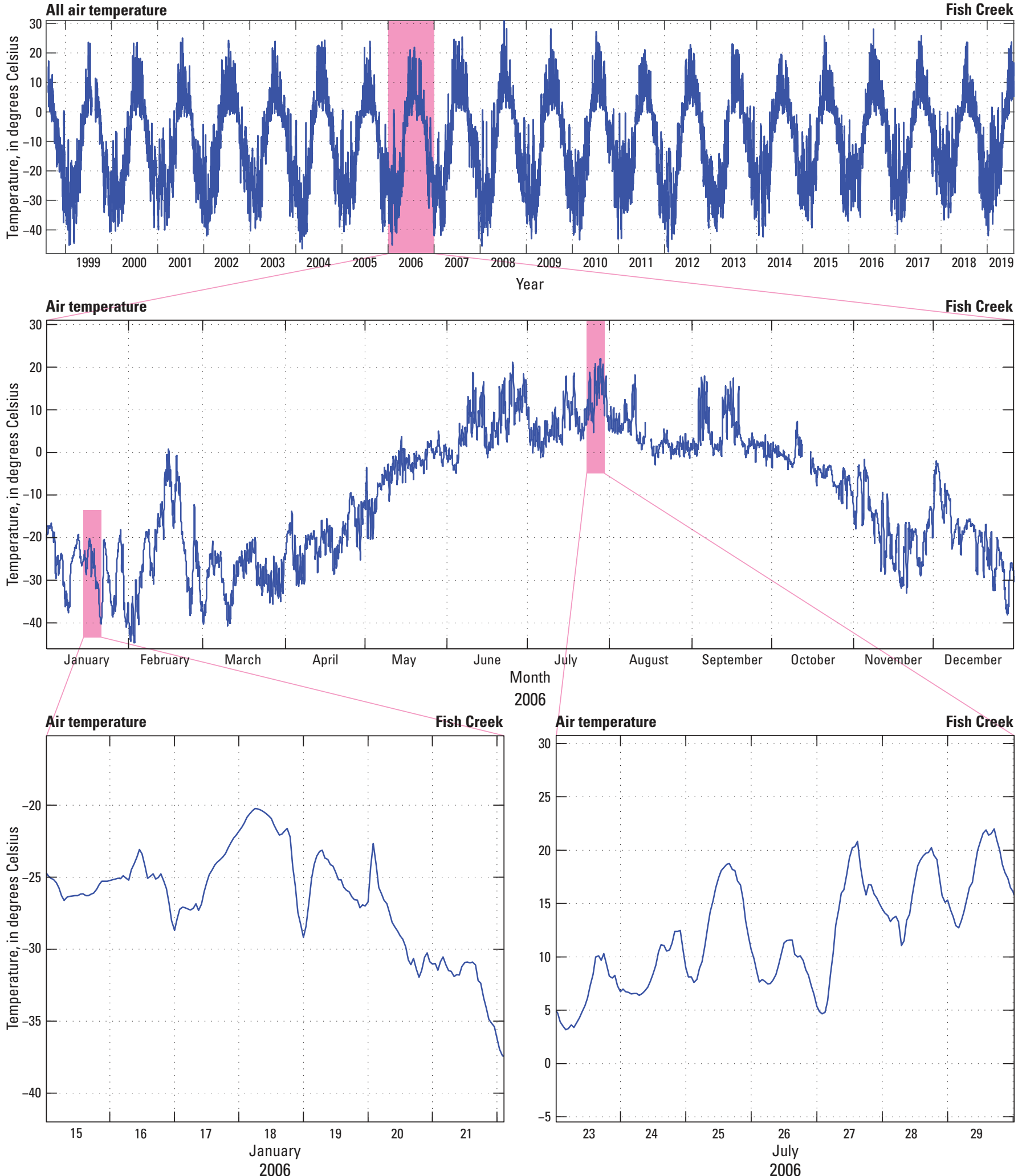

Fish Creek
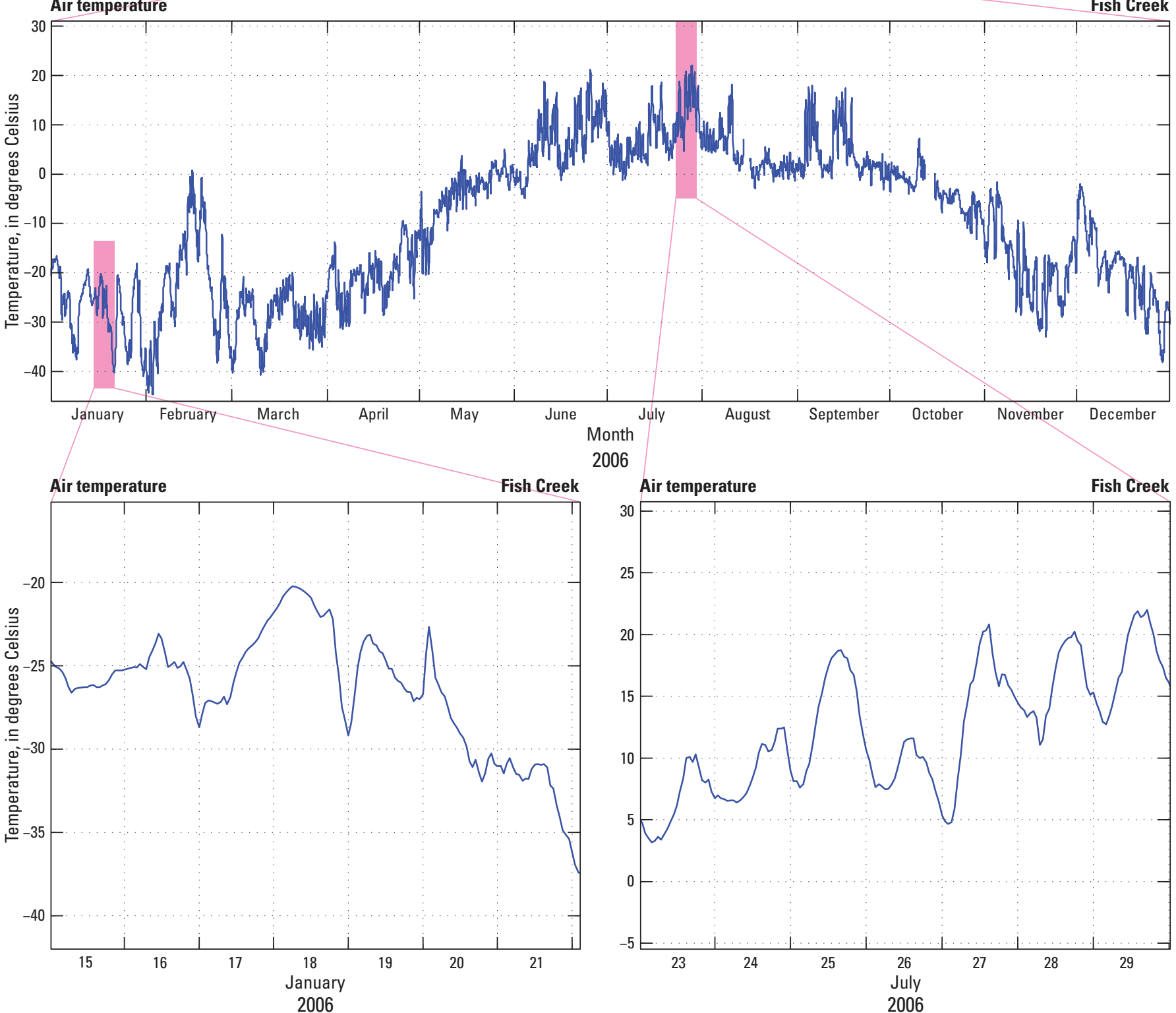

Figure A-3. Sample air temperature record from Fish Creek station. Data are presented at several resolutions with each highlighted section expanded. The top panel shows the full record for the station, the middle panel shows 1 full year (2006), the lower left panel shows 1 week during the winter of 2006, and the lower right panel shows 1 week during the summer of 2006. 

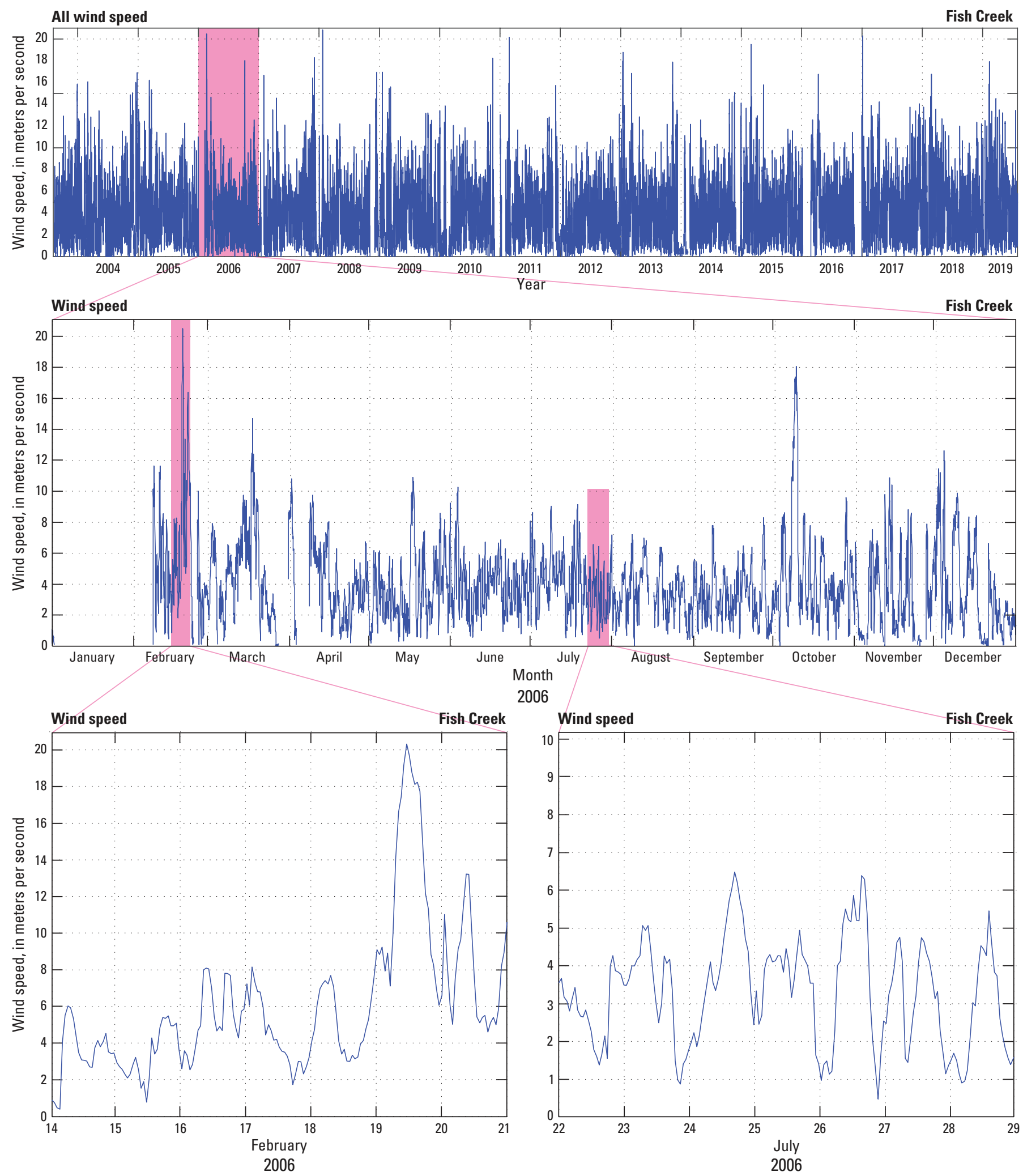

Figure A-4. Sample wind speed record from Fish Creek station. Data are presented at several resolutions with each highlighted section expanded. The top panel shows the full record for the station, the middle panel shows 1 full year (2006), the lower left panel shows 1 week during the winter of 2006, and the lower right panel shows 1 week during the summer of 2006. 
Fish Creek Windroses
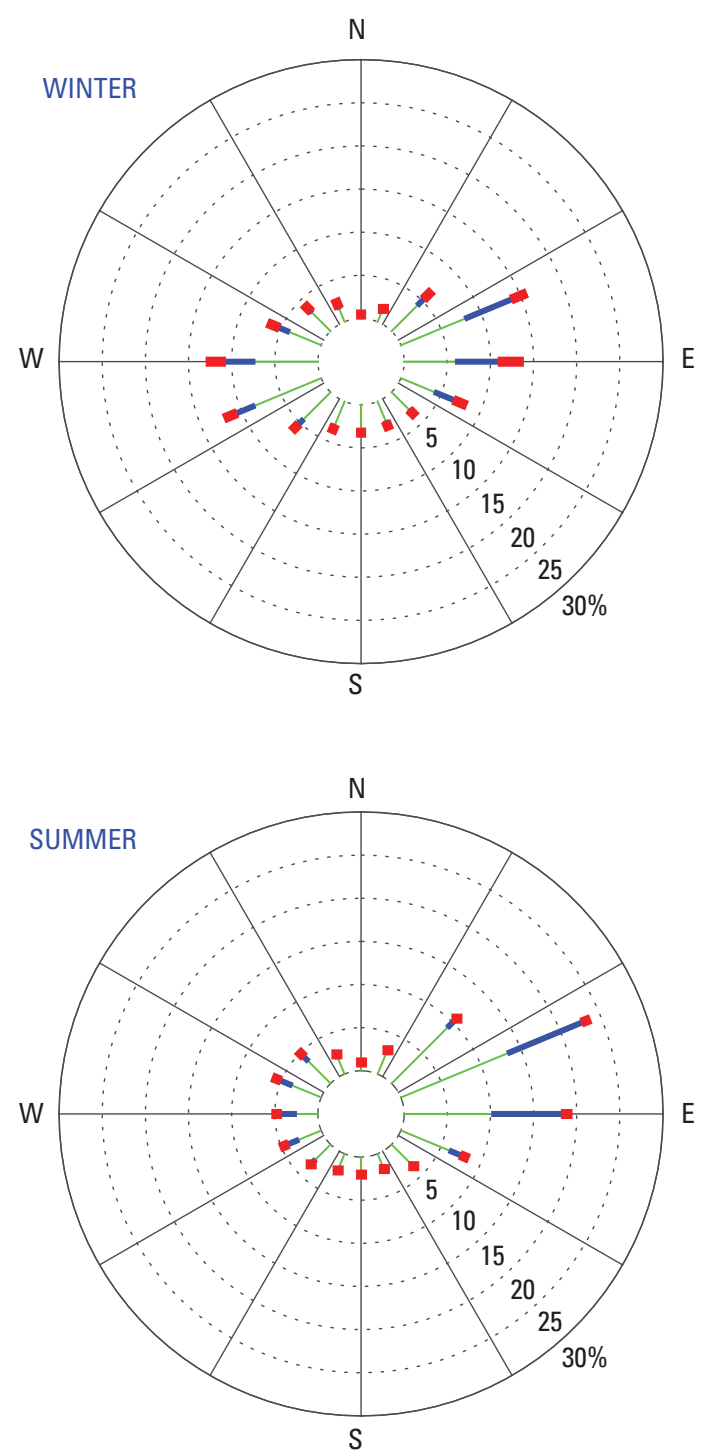

EXPLANATION

Wind speed $(\mathrm{m} / \mathrm{s})$

$0.5<\mathrm{U}<5$

$5<\mathrm{U}<10$
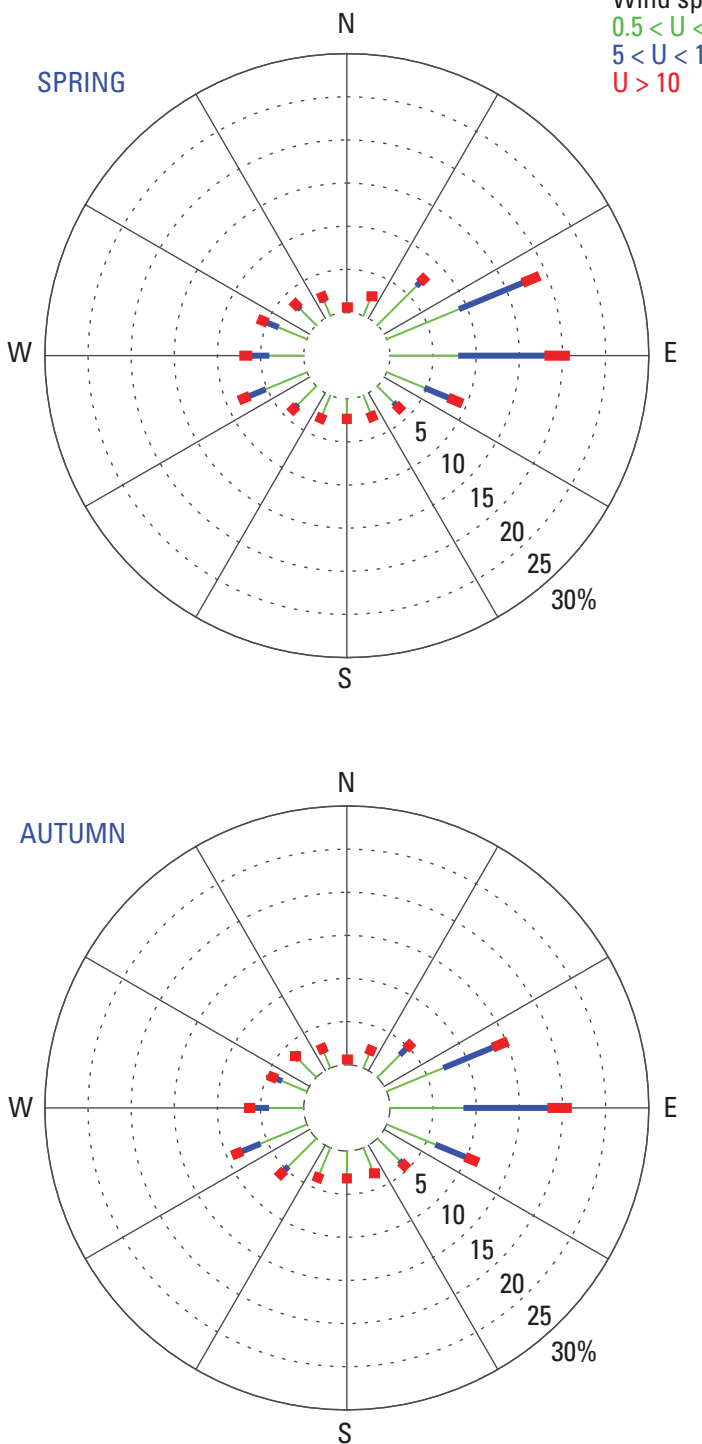

Figure A-5. Sample windroses from Fish Creek station. The wind direction and speed data for a site are divided into 16 wind direction categories $\left(22.5^{\circ}\right.$ each) and 3 wind speed classes: (a) less than 5 meters per second $(\mathrm{m} / \mathrm{s})$, (b) between $5 \mathrm{~m} / \mathrm{s}$ and $10 \mathrm{~m} / \mathrm{s}$, and (c) greater than $10 \mathrm{~m} / \mathrm{s}$. The percentage of time that wind speeds occupy each class and directional category (concentric rings) is presented for each season: winter (December, January, February), spring (March, April, May), summer (June, July, August), and autumn (September, October, November). (U, wind speed; N, north; E, east; S, south; W, west) 

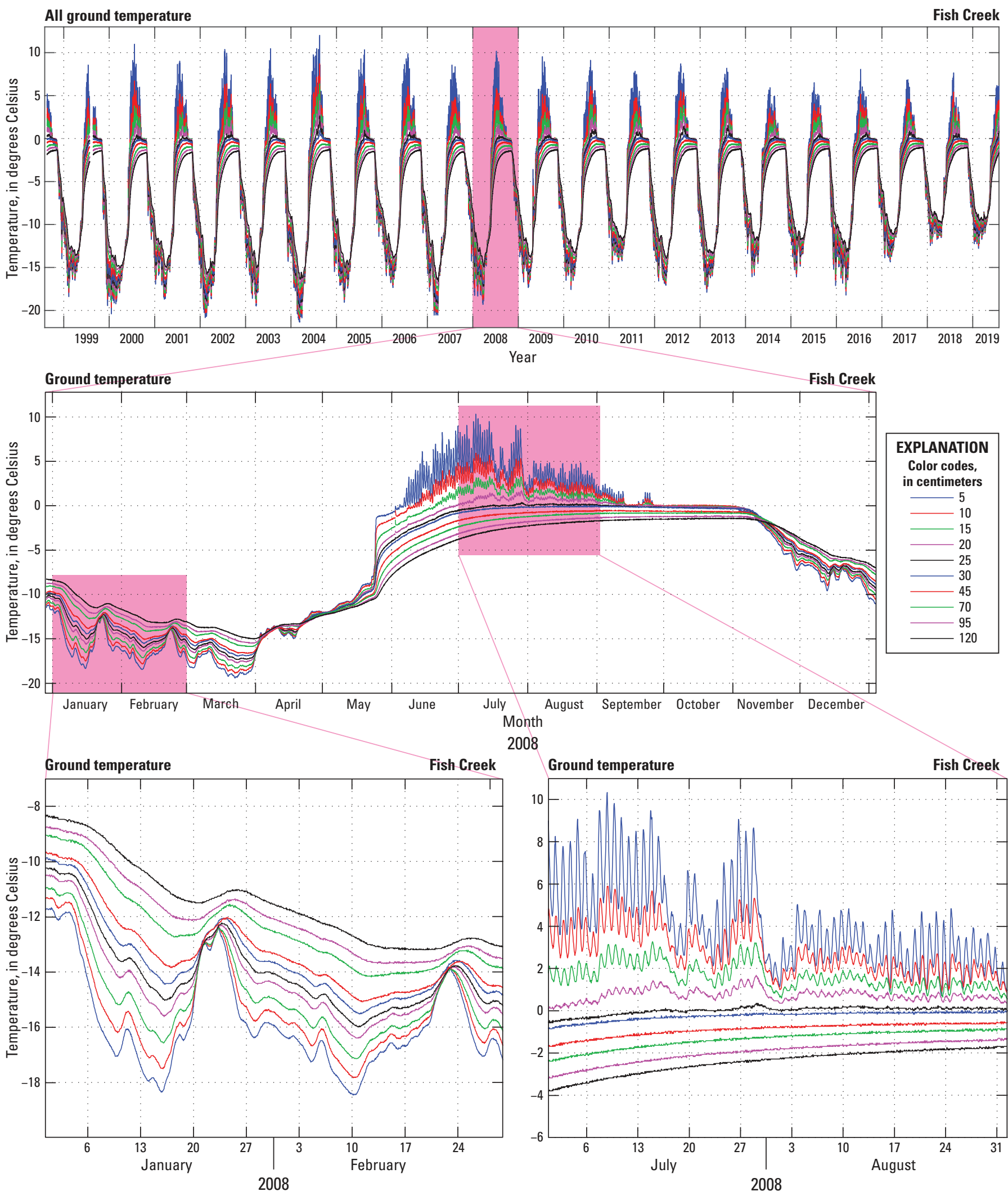

Figure A-6. Sample ground temperature record from Fish Creek station. Data are presented at several resolutions with each highlighted section expanded. The top panel shows the full record for the station, the middle panel shows 1 full year (2008), the lower left panel shows 2 months during the winter of 2008, and the lower right panel shows 2 months during the summer of 2008. (cm, centimeter) 

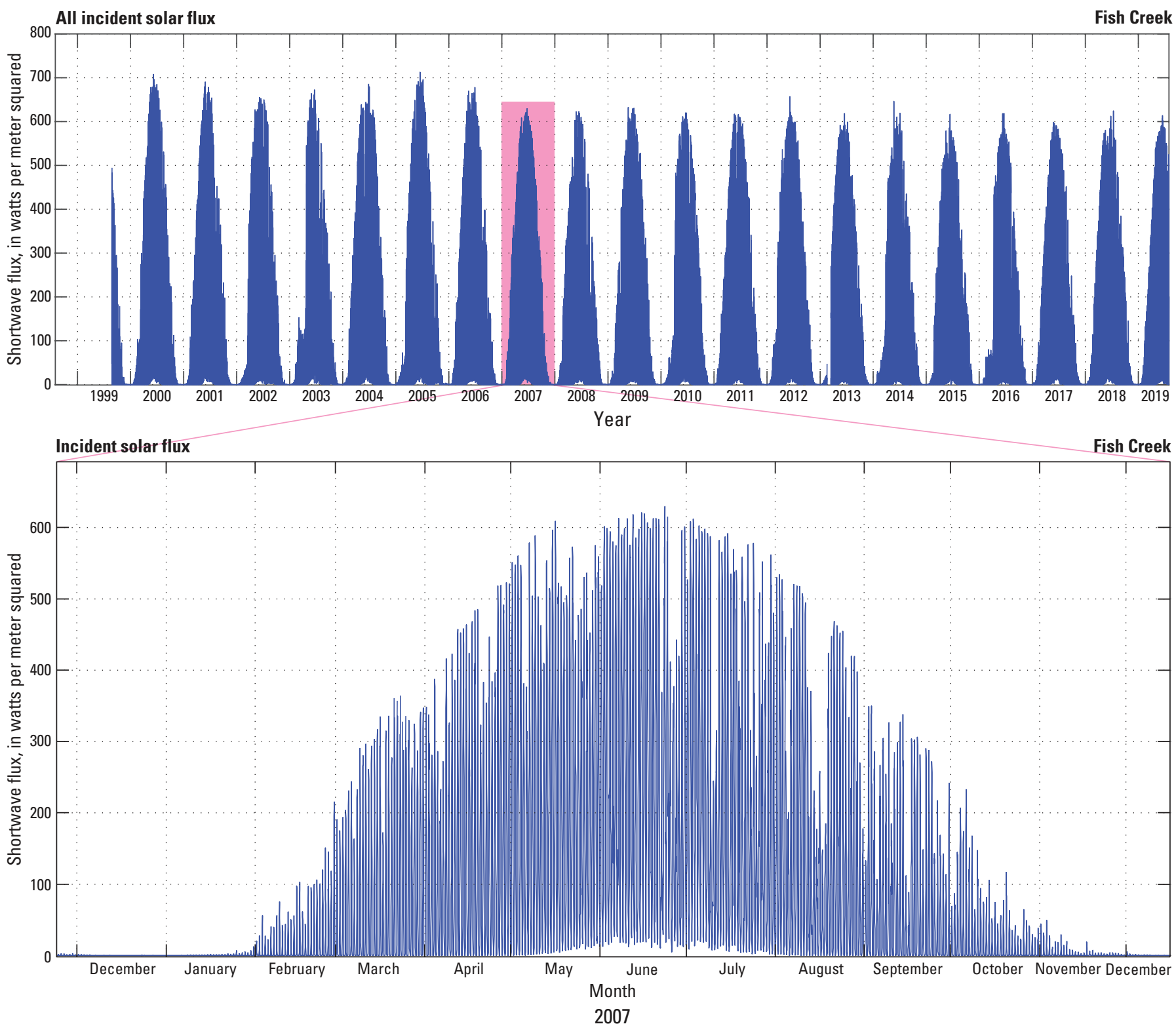

Figure A-7. Sample incident solar-flux record from Fish Creek station. Data are presented at two resolutions with one highlighted section expanded. The top panel shows the full record for the station; the bottom panel shows 1 full year (2007). 

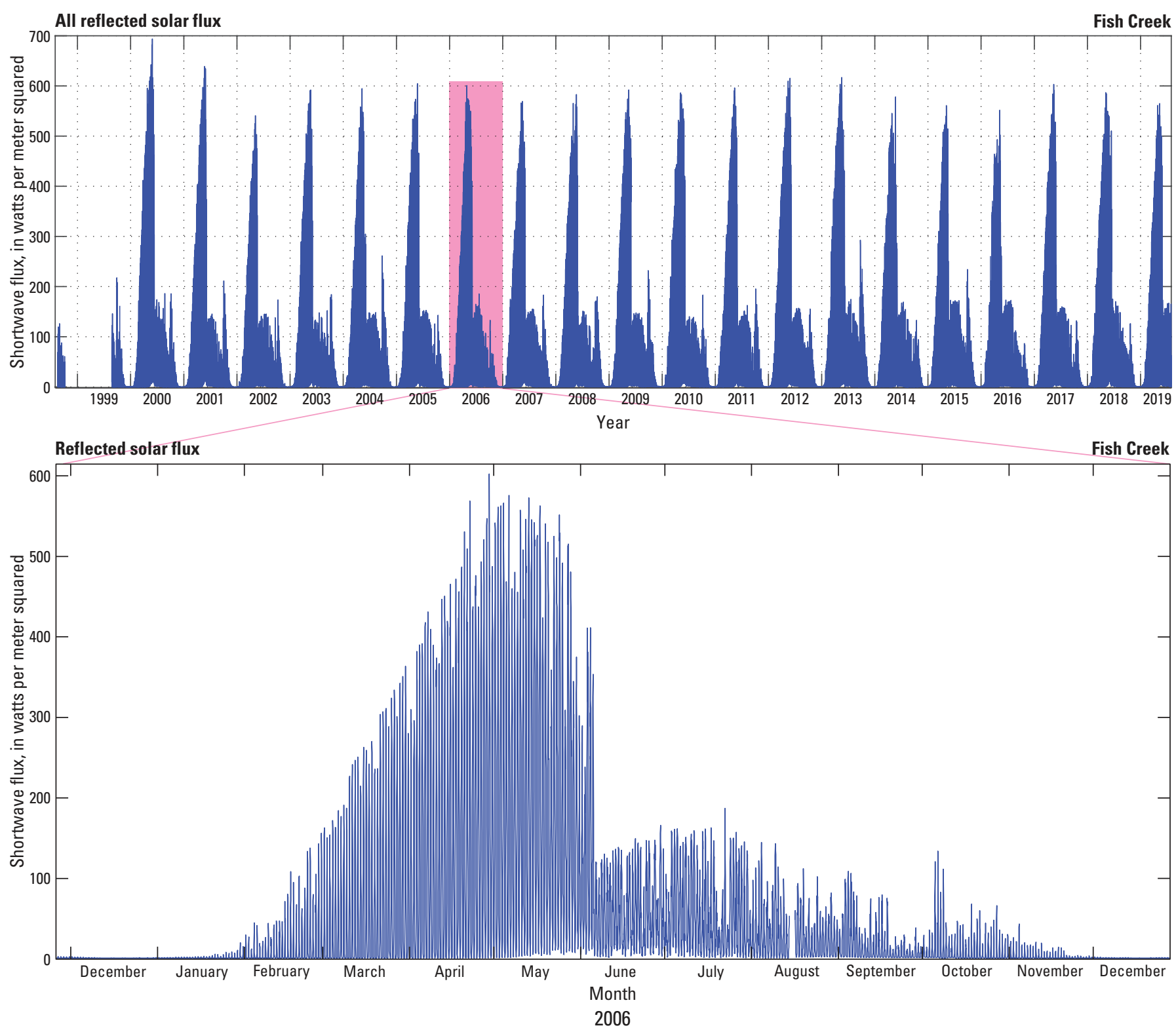

Figure A-8. Sample reflected solar-flux record from Fish Creek station. Data are presented at two resolutions with one highlighted section expanded. The top panel shows the full record for the station; the bottom panel shows 1 full year (2006). 

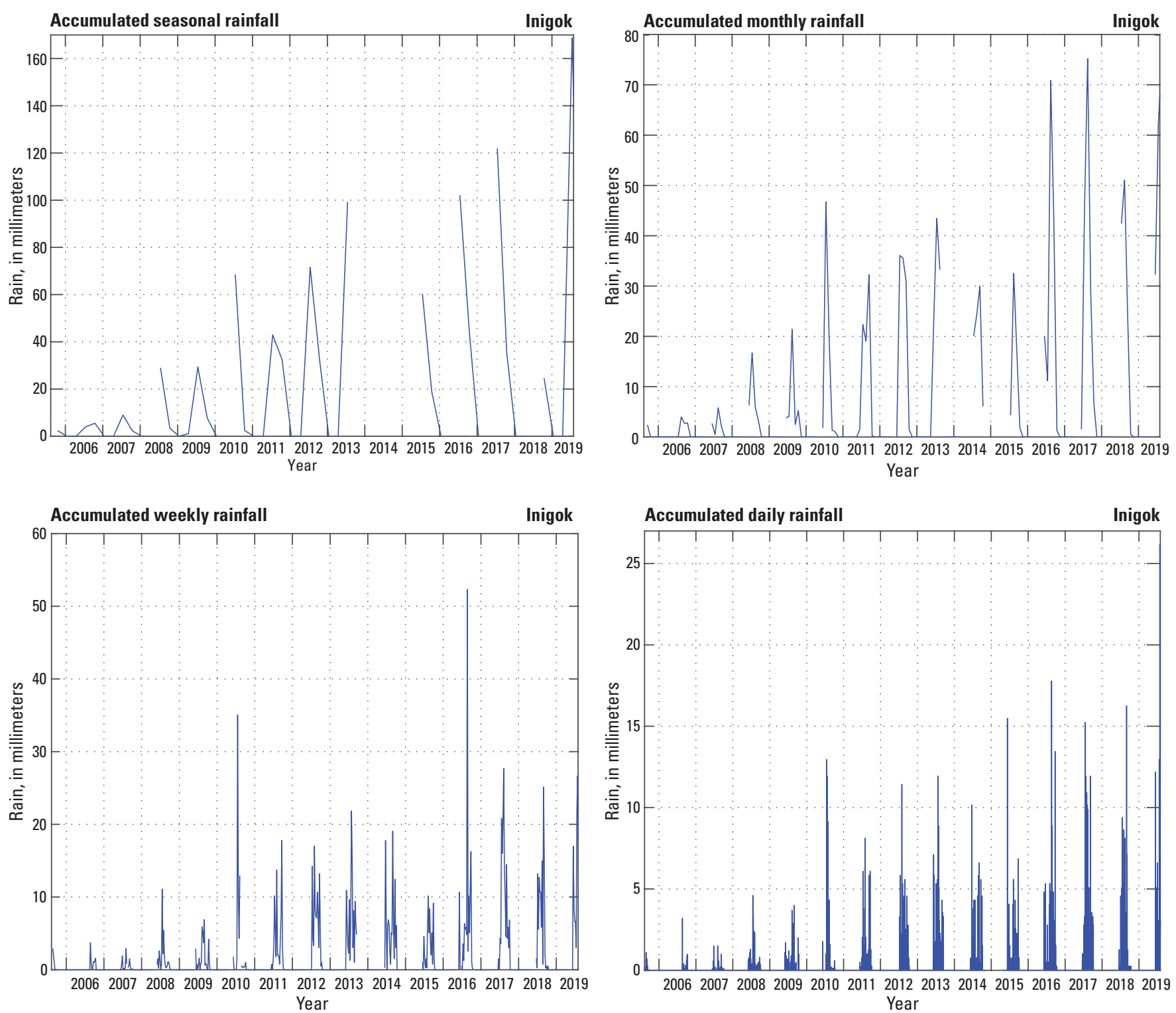

Figure A-9. Sample rainfall record from Inigok station. Data are presented at several resolutions. The top left panel shows the accumulated rainfall at seasonal resolution, the top right panel shows the accumulated rainfall at monthly resolution, the bottom left panel shows the accumulated rainfall at weekly resolution, and the bottom right panel shows the accumulated rainfall at daily resolution. 

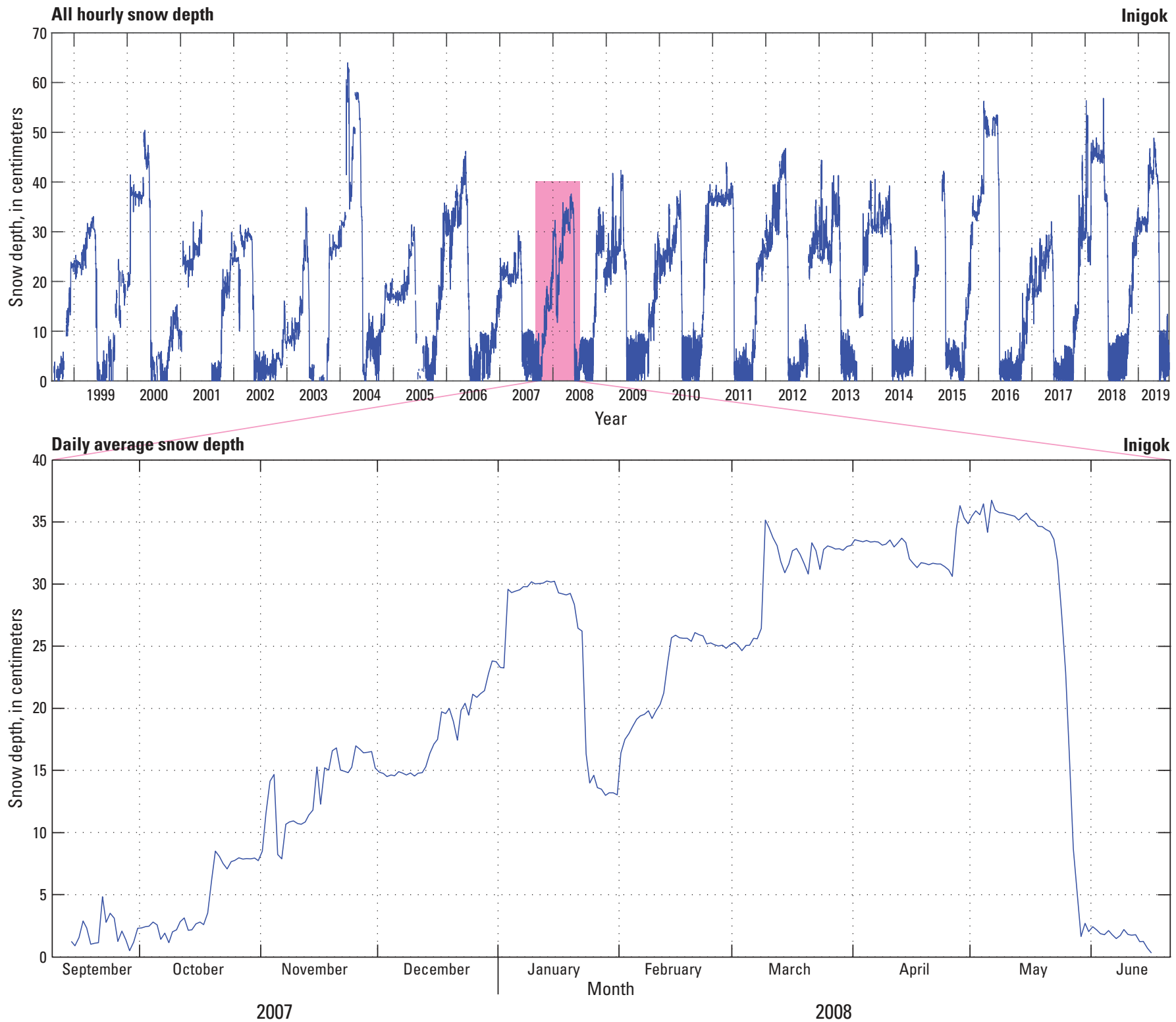

Figure A-10. Sample snow depth record from Inigok station. Data are presented at two resolutions with one highlighted section expanded. The top panel shows the full record for the station; the bottom panel shows daily averages for one full snow-cover season, September 2007 through June 2008. 

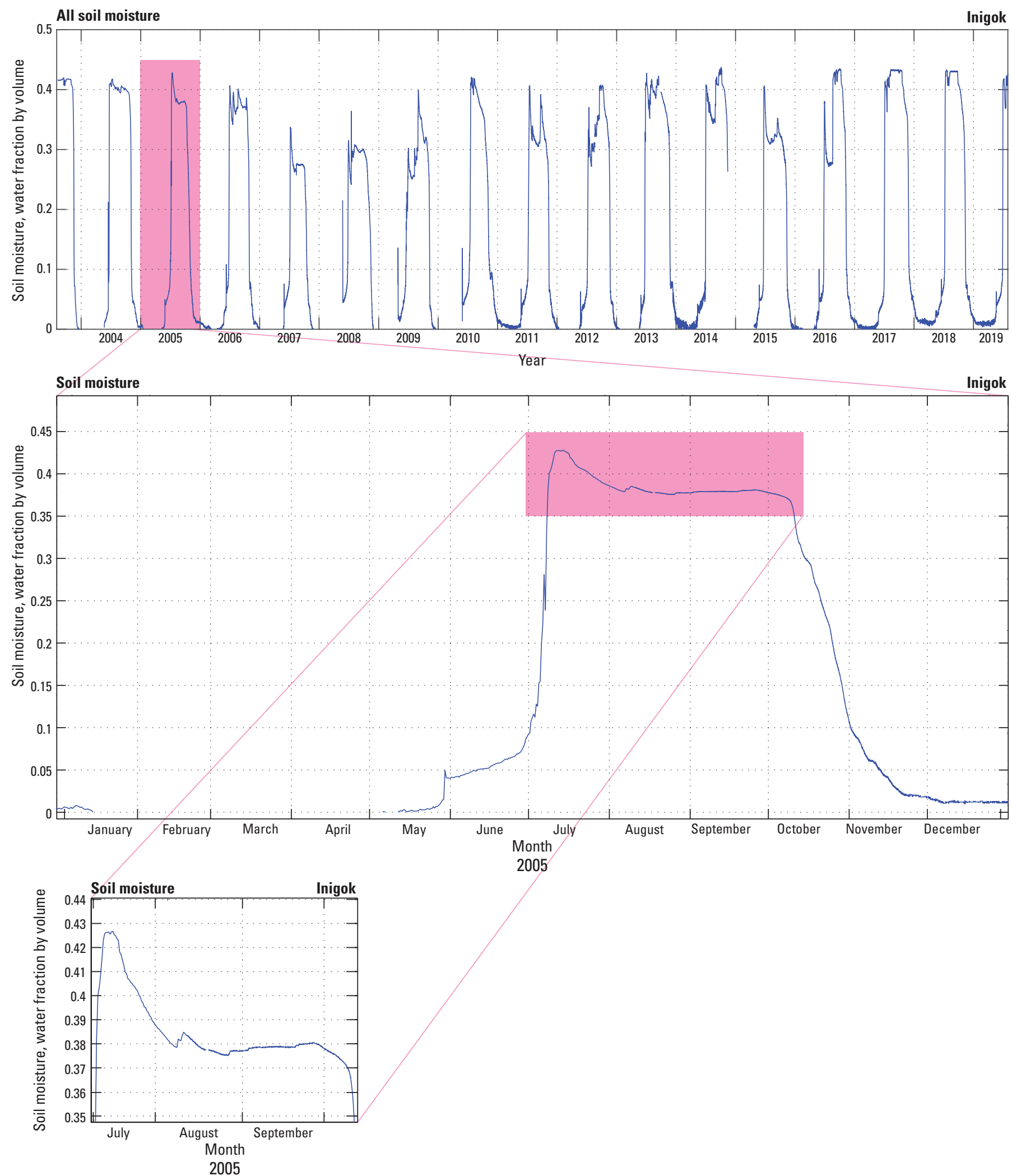

Figure A-11. Sample soil moisture record at 15-centimeter depth from Inigok station. Data are presented at several resolutions with each highlighted section expanded. The top panel shows the full record for the station, the bottom panel shows 1 full year (2006), and the inset shows detail during the unfrozen season, July through October, 2006. 

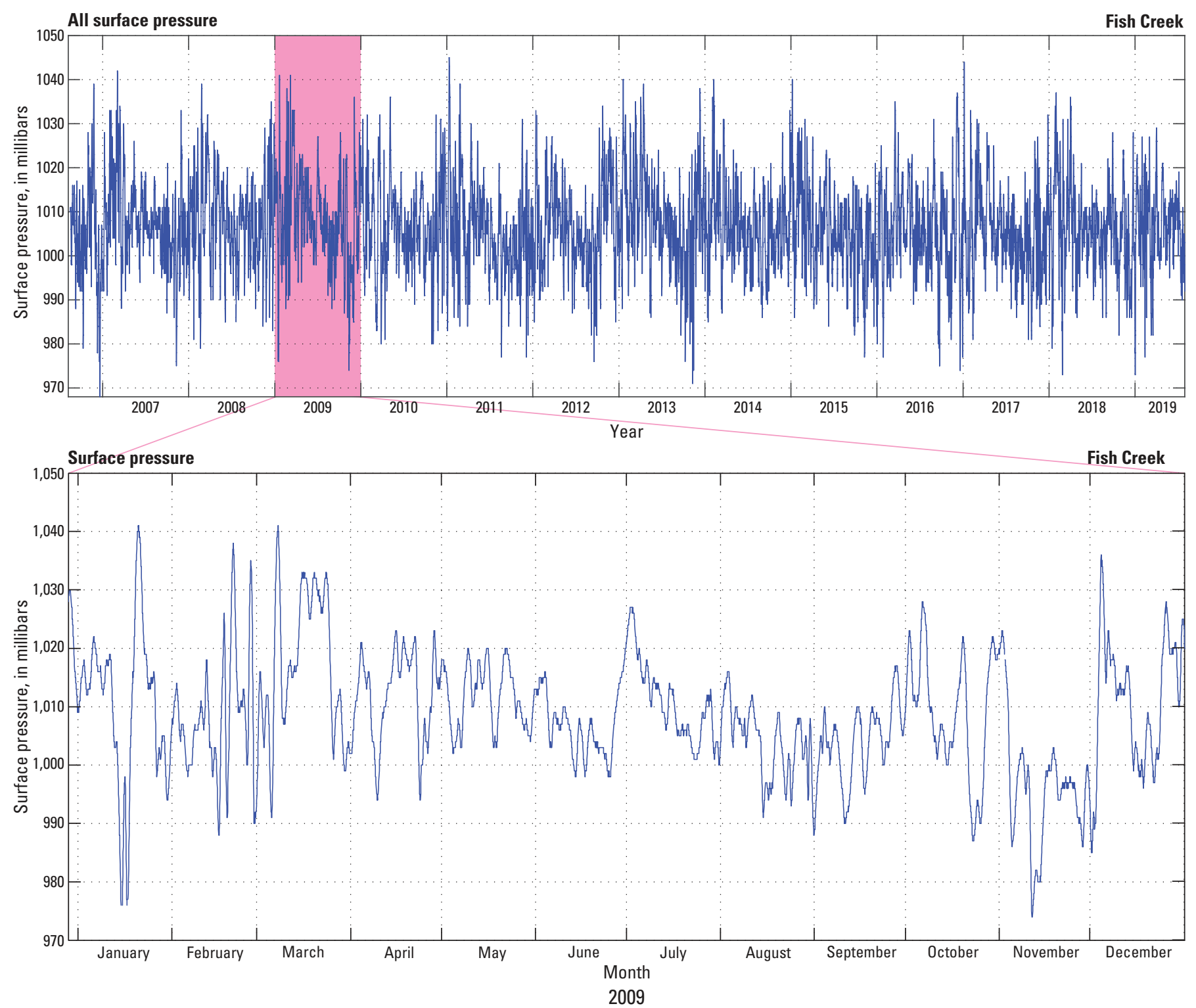

Figure A-12. Sample surface pressure record from Fish Creek station. Data are presented at two resolutions with one highlighted section expanded. The top panel shows the full record for the station; the bottom panel shows 1 full year (2009). 


\section{B. Drew Point}

GTN-P code: U20

Latitude: $70^{\circ} 51.872^{\prime} \mathrm{N}$

Longitude: $153^{\circ} 54.405^{\prime} \mathrm{W}$

Elevation: 5 meters above mean sea level

Installation date: 18 AUG 1998

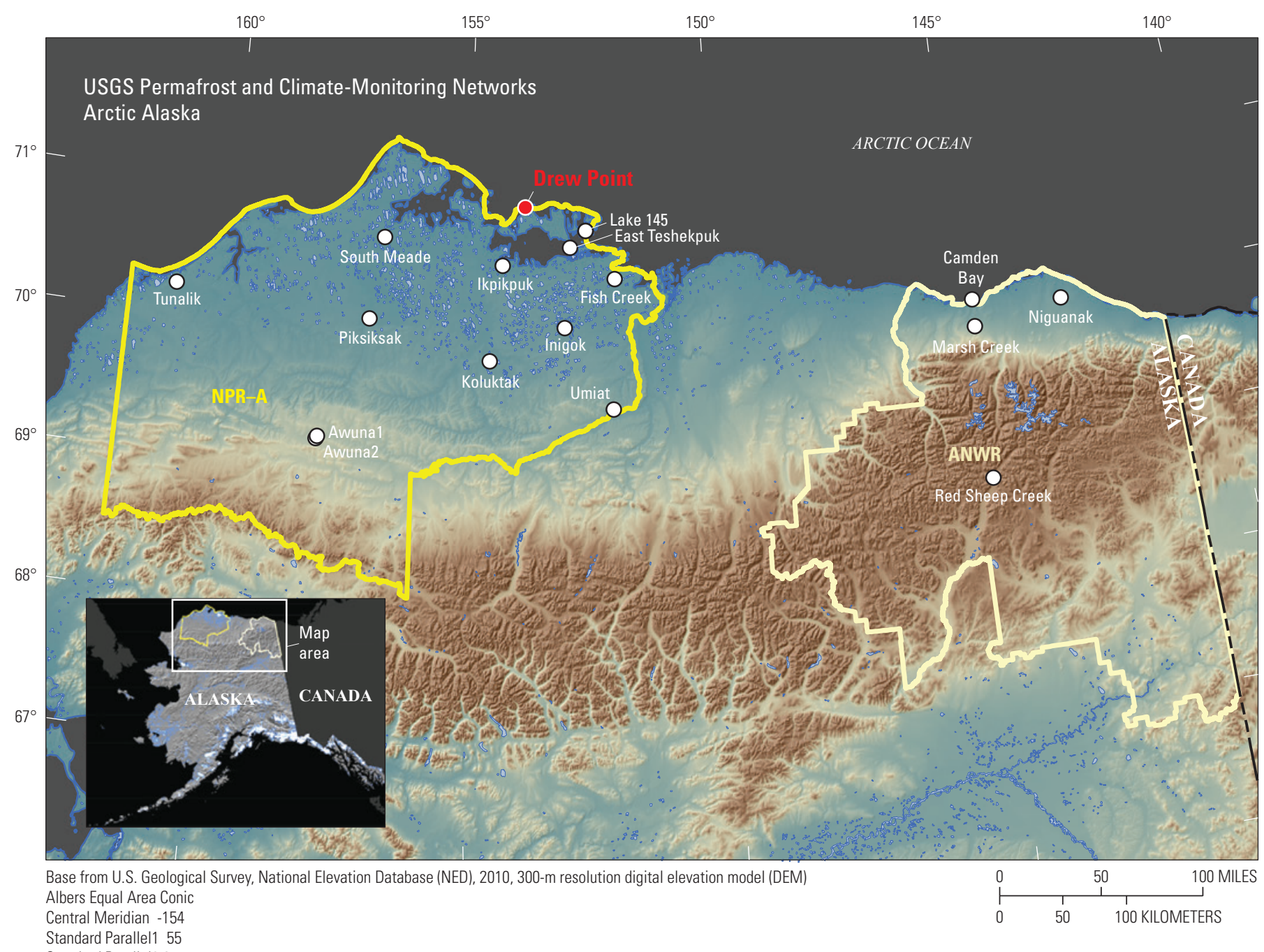

Stard Parallel1 55

Figure B-1. Location map presenting the specific location of the Drew Point site and its spatial relation to other sites in the monitoring network. (NPR-A, National Petroleum Reserve-Alaska; ANWR, Arctic National Wildlife Refuge) 


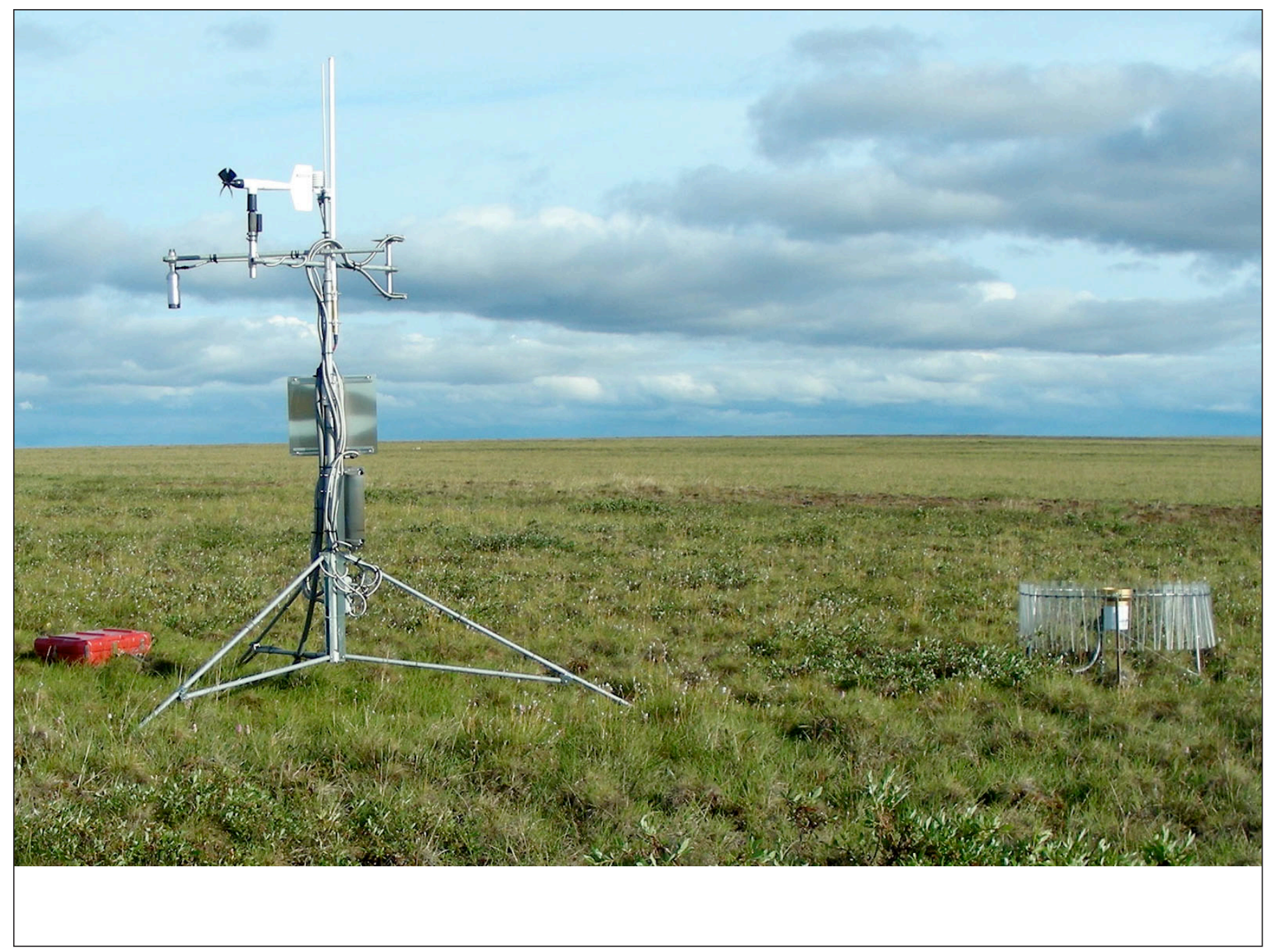

Figure B-2. Drew Point station in summer 2008. 
Drew Point Windroses
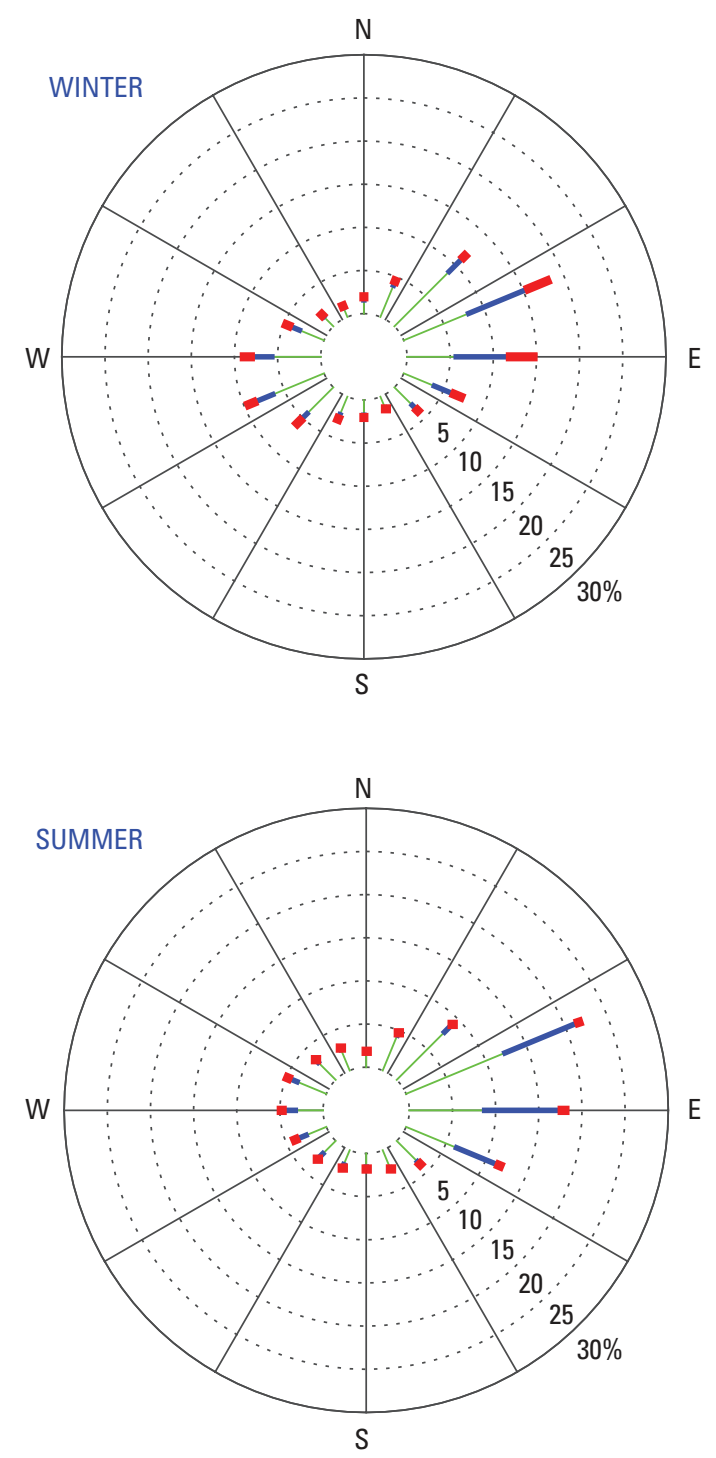
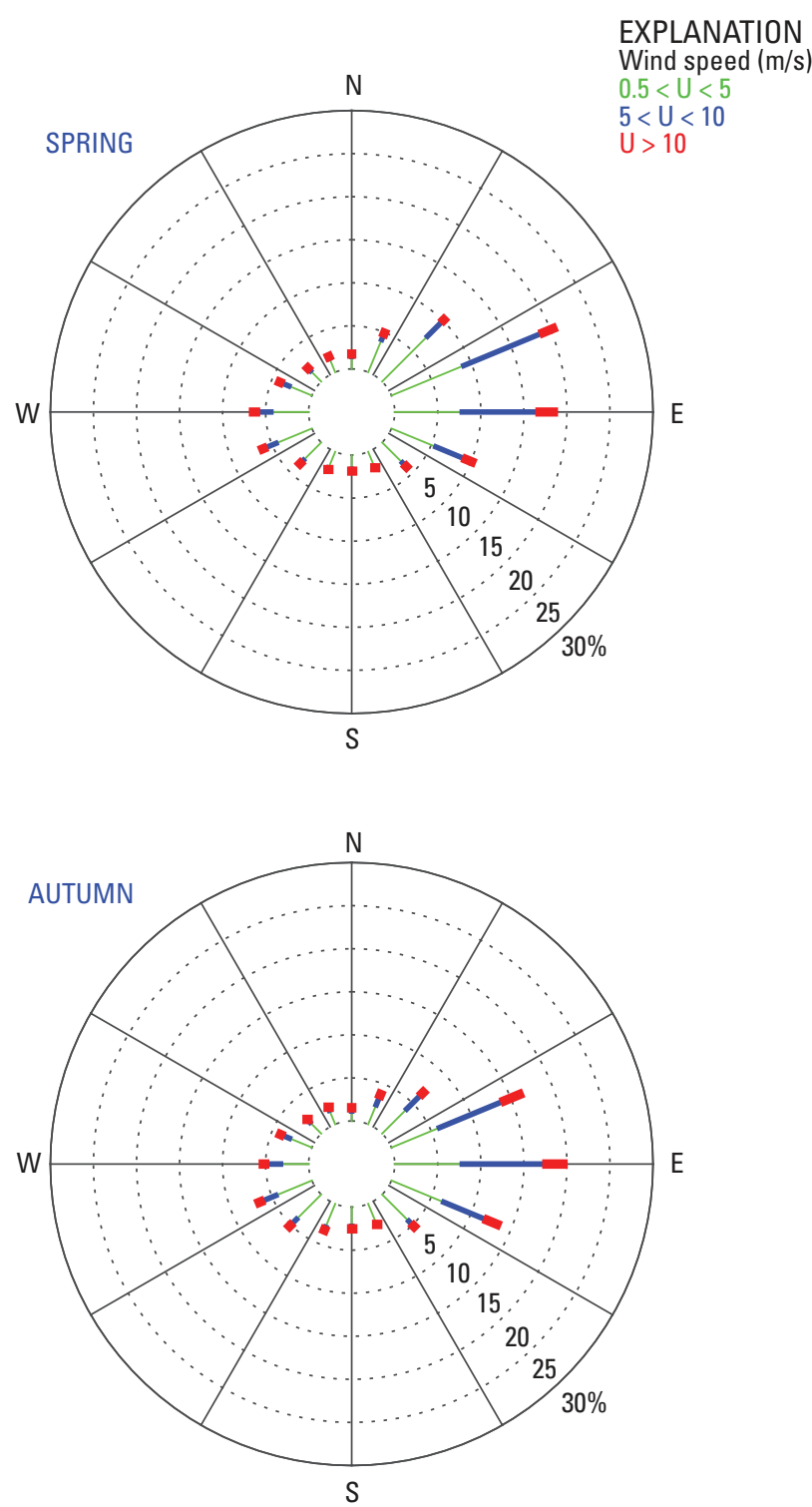

Figure B-3. Drew Point seasonal windroses. The wind direction and speed data are divided into 16 wind direction categories $\left(22.5^{\circ}\right.$ each) and 3 wind speed classes: less than $5 \mathrm{~m} / \mathrm{s}$, between $5 \mathrm{~m} / \mathrm{s}$ and $10 \mathrm{~m} / \mathrm{s}$, and greater than $10 \mathrm{~m} / \mathrm{s}$. The percentage of time that wind speeds occupy each class and directional category (concentric rings) is presented for each season: winter (December, January, February), spring (March, April, May), summer (June, July, August), and autumn (September, October, November). (m/s, meters per second; U, wind speed; N, north; E, east; S, south; W, west)

\section{Data Access}

List of station data ScienceBase data release files and summary tables for this report are available at https://doi.org/10.5066/F7VX0FGB. 


\section{Inigok}

GTN-P code: U21

Latitude: $69^{\circ} 59.377^{\prime} \mathrm{N}$

Longitude: $153^{\circ} 05.630^{\prime} \mathrm{W}$

Elevation: 53 meters above mean sea level

Installation date: 17 AUG 1998

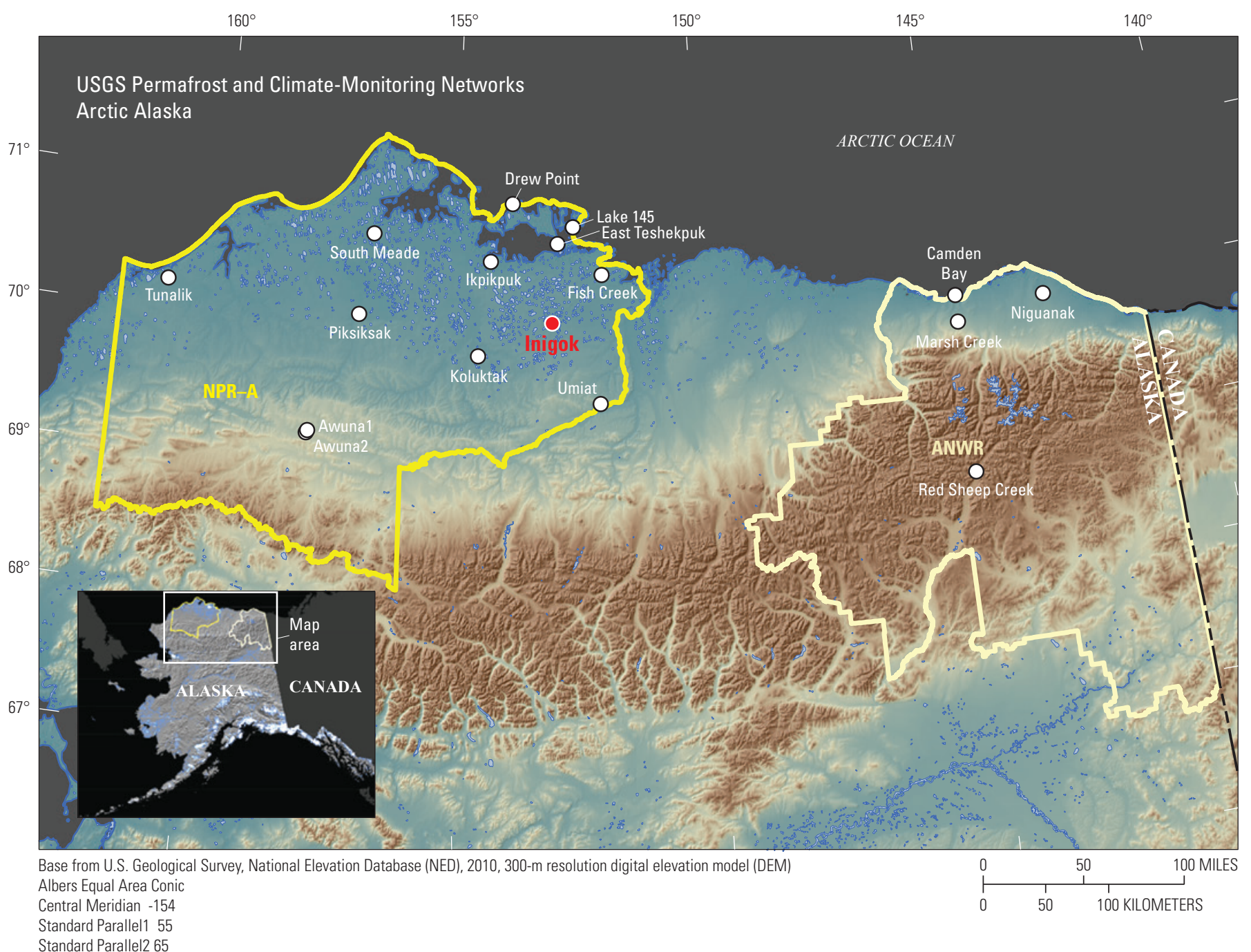

Figure C-1. Location map presenting the specific location of the Inigok site and its spatial relation to other sites in the monitoring network. (NPR-A, National Petroleum Reserve-Alaska; ANWR, Arctic National Wildlife Refuge) 


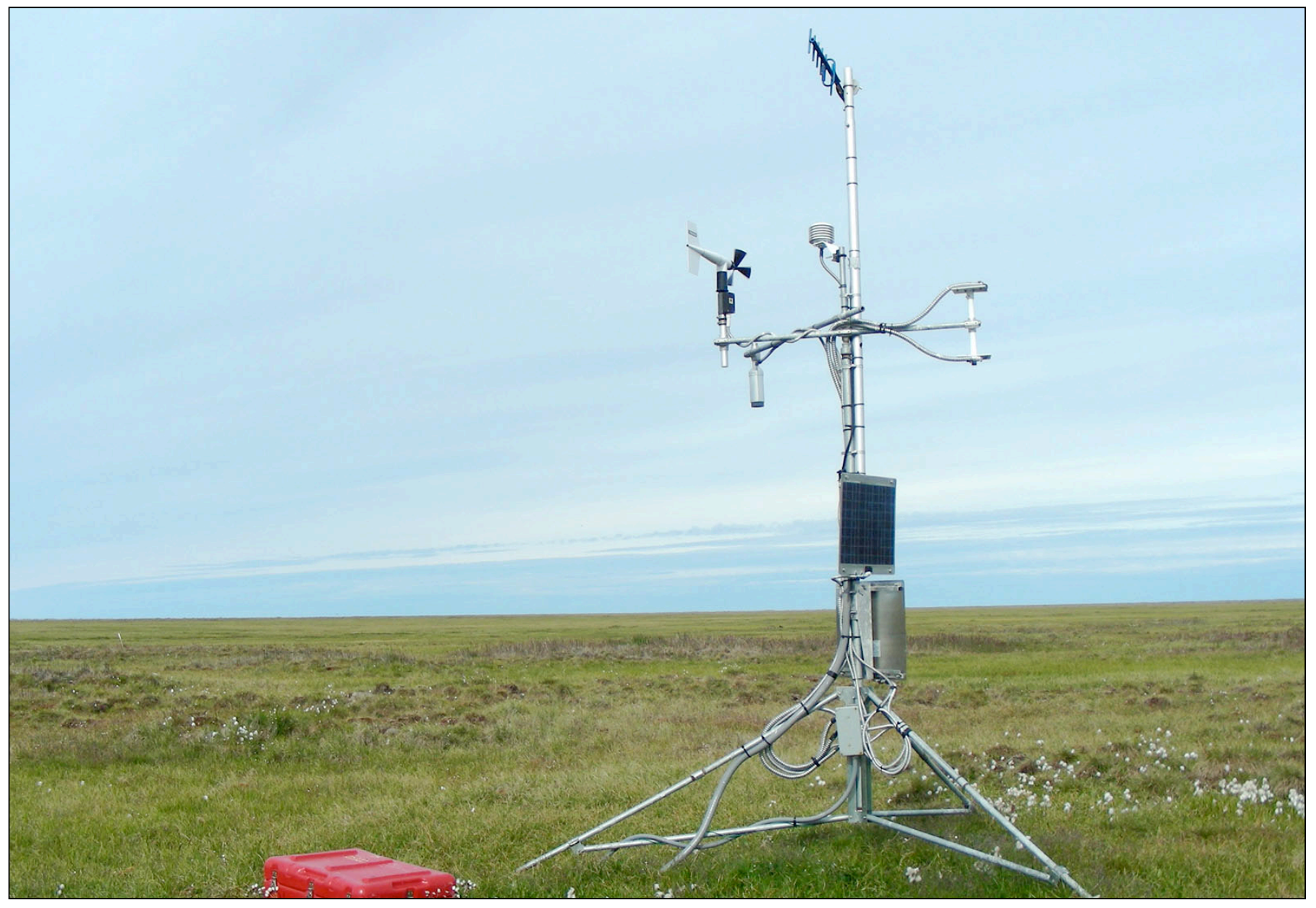

Figure C-2. Inigok station in summer 2008. 
Inigok Windroses
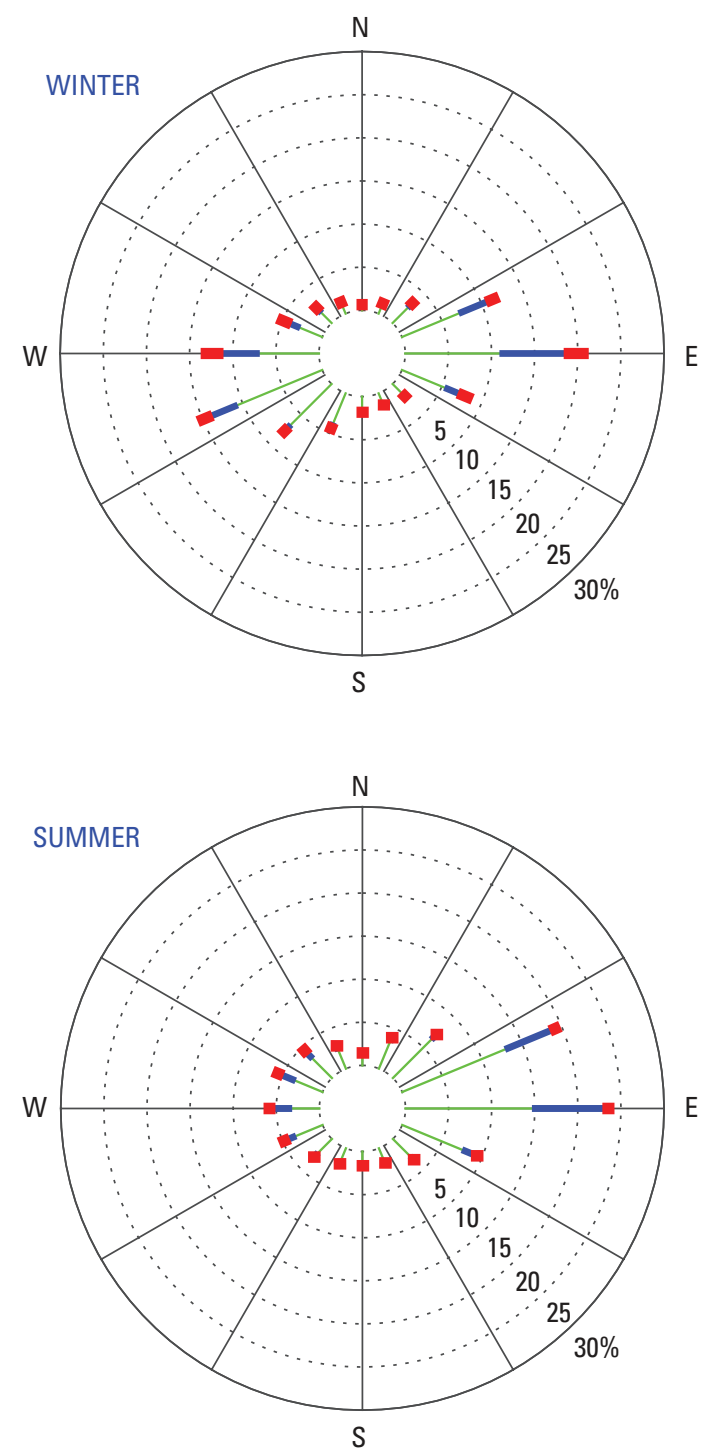
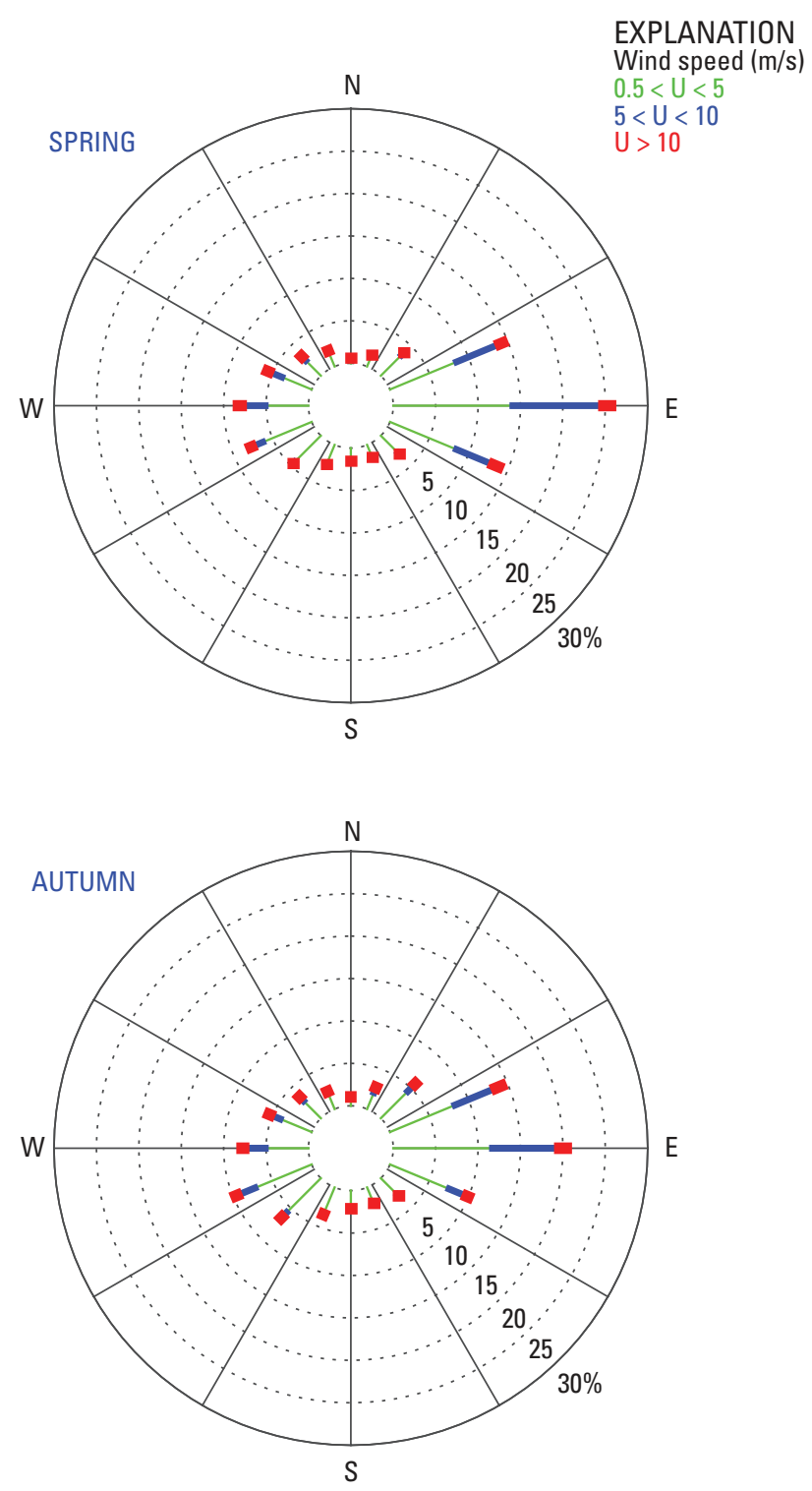

Figure C-3. Inigok seasonal windroses. The wind direction and speed data are divided into 16 wind direction categories $\left(22.5^{\circ}\right.$ each $)$ and 3 wind speed classes: less than $5 \mathrm{~m} / \mathrm{s}$, between $5 \mathrm{~m} / \mathrm{s}$ and $10 \mathrm{~m} / \mathrm{s}$, and greater than $10 \mathrm{~m} / \mathrm{s}$. The percentage of time that wind speeds occupy each class and directional category (concentric rings) is presented for each season: winter (December, January, February), spring (March, April, May), summer (June, July, August), and autumn (September, October, November). (m/s, meters per second; U, wind speed; N, north; E, east; S, south; W, west)

Data Access

List of station data ScienceBase data release files and summary tables for this report are available at https://doi.org/10.5066/F7VX0FGB. 


\section{Fish Creek}

GTN-P code: U22

Latitude: $70^{\circ} 20.114 \mathrm{~N}$

Longitude: $152^{\circ} 03.120^{\prime} \mathrm{W}$

Elevation: 31 meters above mean sea level

Installation date: 18 AUG 1998

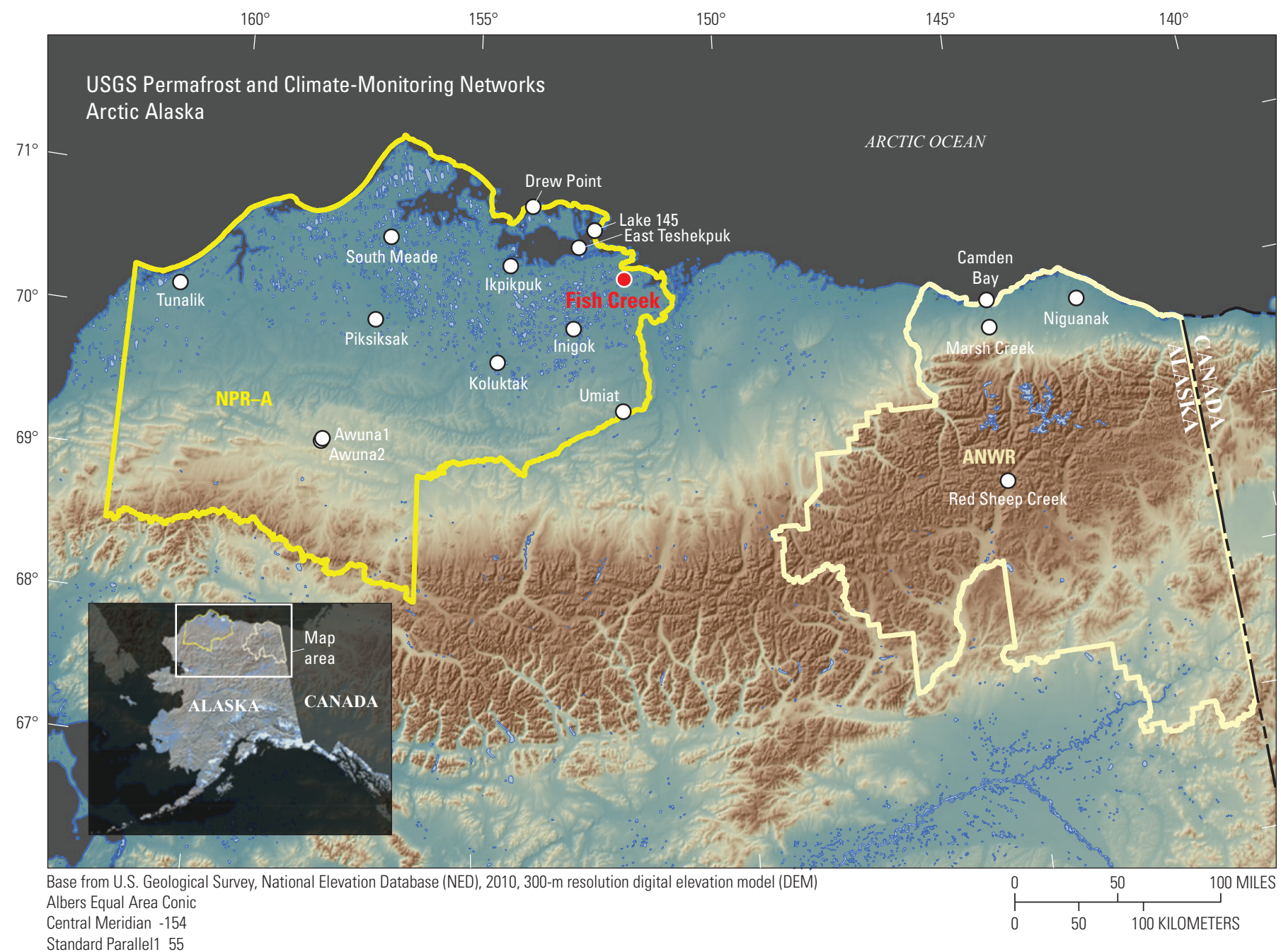

Standard Paralle1 55

Standard Parallel2 65

Figure D-1. Location map presenting the specific location of the Fish Creek site and its spatial relationship to other sites in the monitoring network. (NPR-A, National Petroleum Reserve-Alaska; ANWR, Arctic National Wildlife Refuge) 


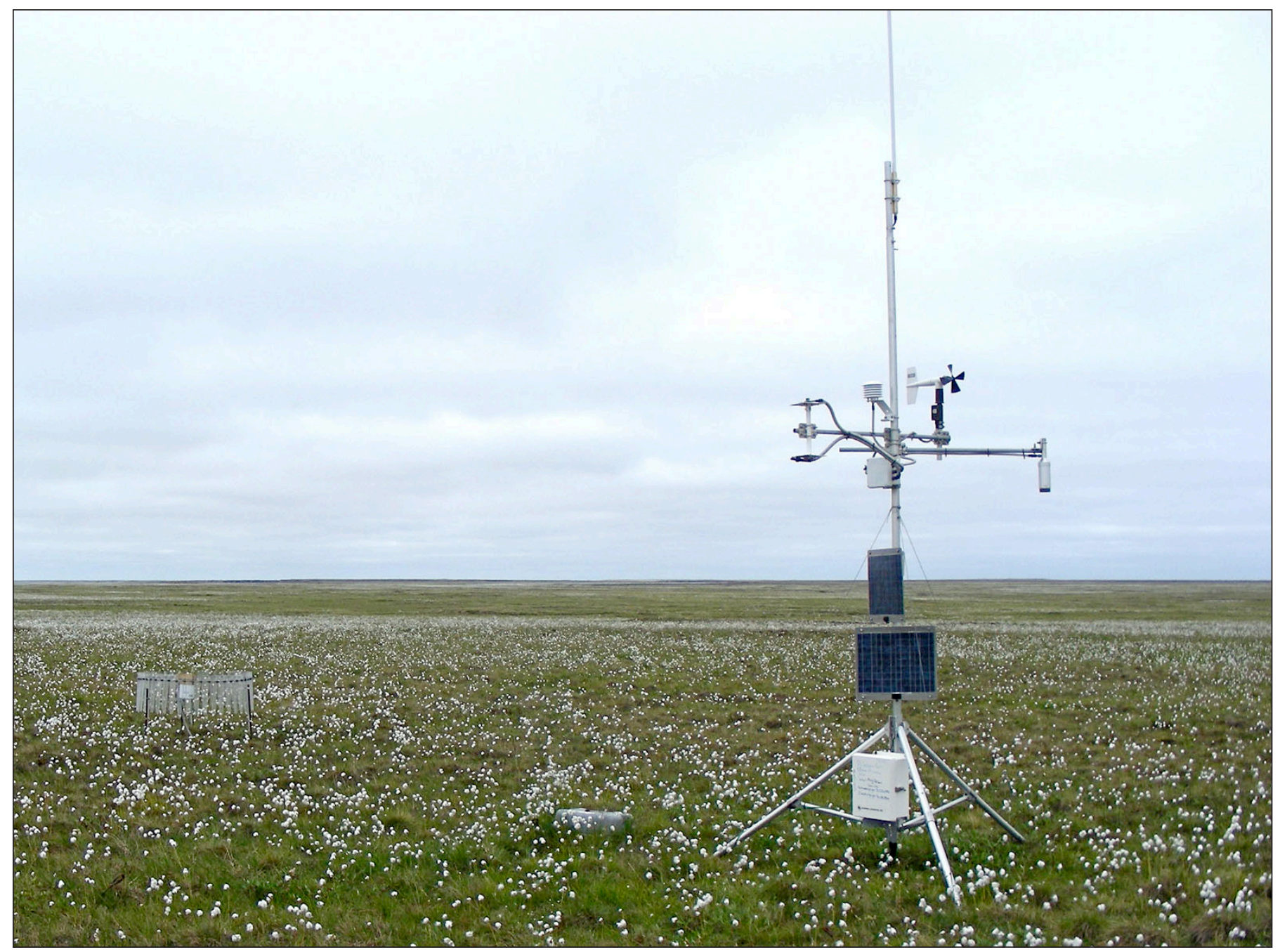

Figure D-2. Fish Creek station in summer 2008. 
Fish Creek Windroses
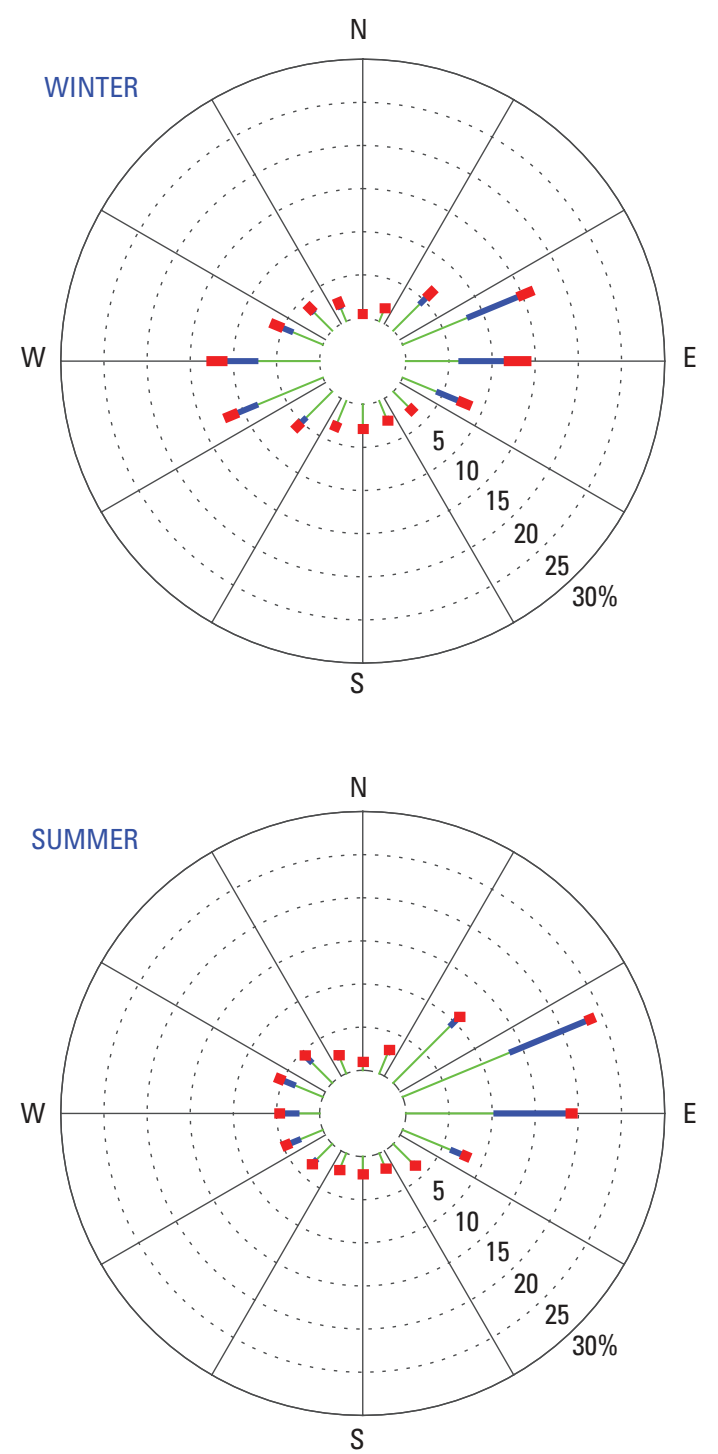
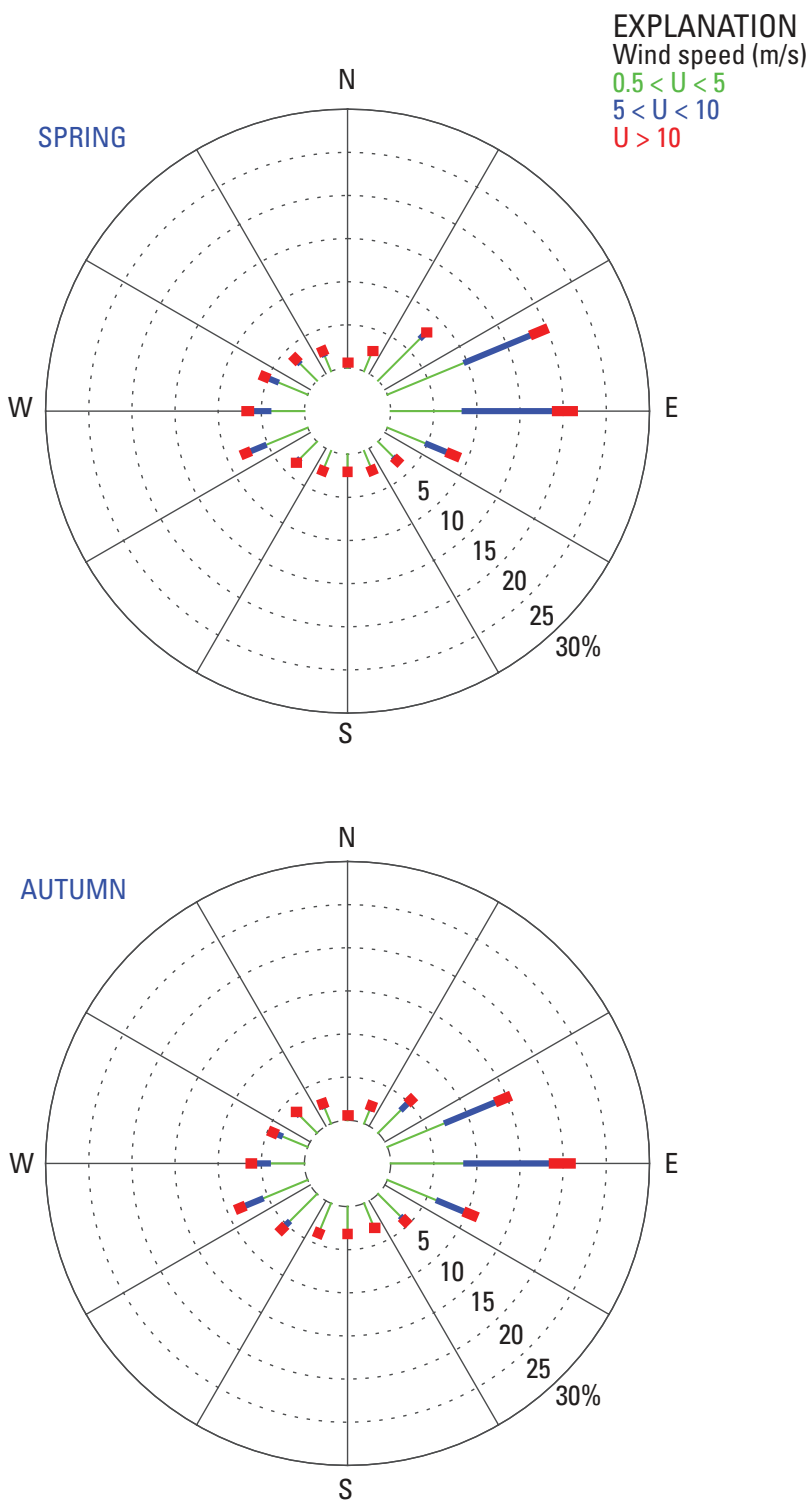

Figure D-3. Fish Creek seasonal windroses. The wind direction and speed data are divided into 16 wind direction categories $\left(22.5^{\circ}\right.$ each) and 3 wind speed classes: less than $5 \mathrm{~m} / \mathrm{s}$, between $5 \mathrm{~m} / \mathrm{s}$ and $10 \mathrm{~m} / \mathrm{s}$, and greater than $10 \mathrm{~m} / \mathrm{s}$. The percentage of time that wind speeds occupy each class and directional category (concentric rings) is presented for each season: winter (December, January, February), spring (March, April, May), summer (June, July, August), and autumn (September, October, November). (m/s, meter per second; U, wind speed; N, north; E, east; S, south; W, west)

List of station data ScienceBase data release files and summary tables for this report are available at https://doi.org/10.5066/F7VX0FGB. 


\section{E. Awuna1}

GTN-P code: U23

Latitude: $69^{\circ} 10.226^{\prime} \mathrm{N}$

Longitude: $158^{\circ} 00.402^{\prime} \mathrm{W}$

Elevation: 362 meters above mean sea level

Installation date: 19 AUG 1998

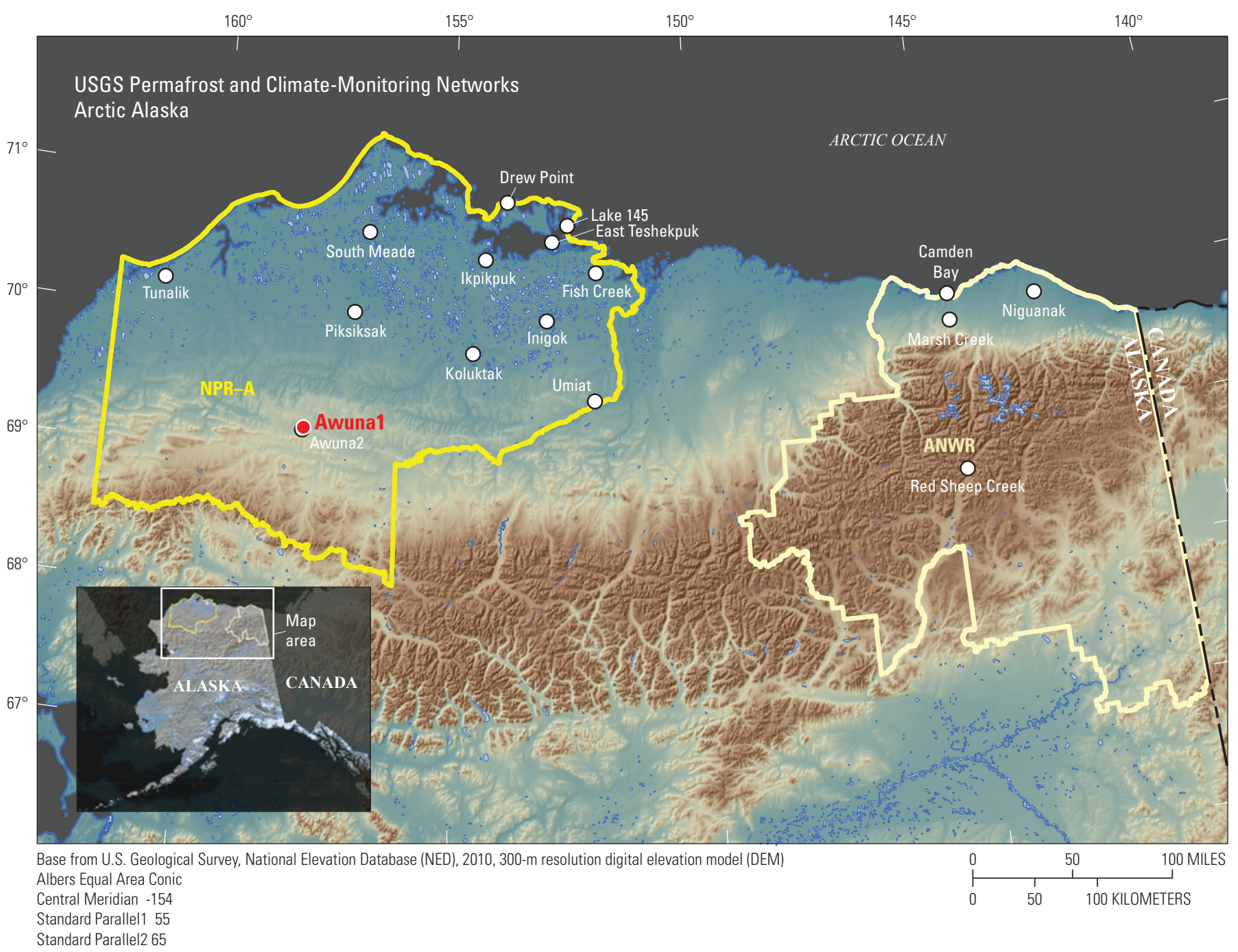

Figure E-1. Location map presenting the specific location of the Awuna1 site and its spatial relation to other sites in the monitoring network. (NPR-A, National Petroleum Reserve-Alaska; ANWR, Arctic National Wildlife Refuge) 


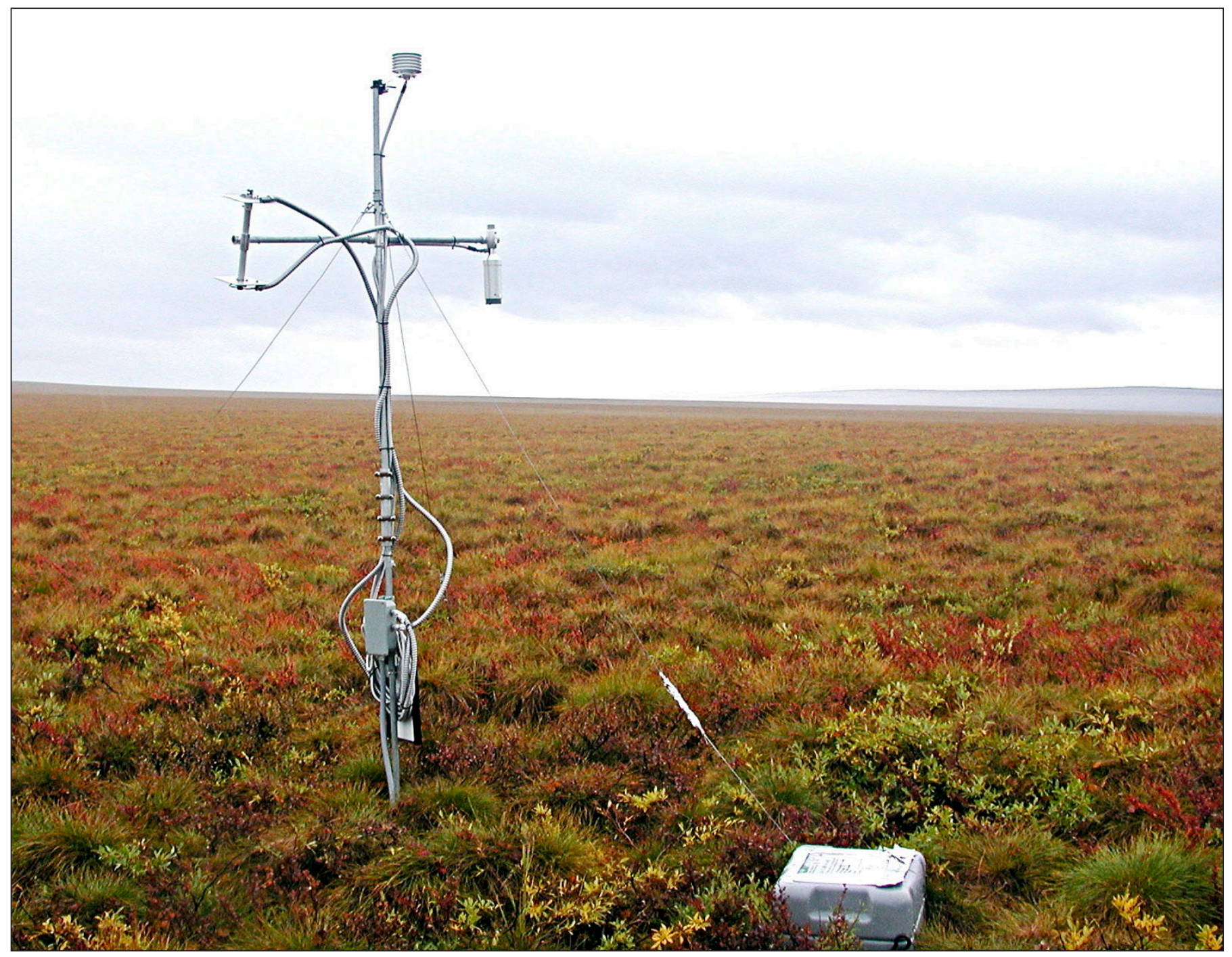

Figure E-2. Awuna1 station in summer 2008.

Data Access

List of station data ScienceBase data release files and summary tables for this report are available at https://doi.org/10.5066/F7VX0FGB. 


\section{F. Umiat}

GTN-P code: U24

Latitude: $69^{\circ} 23.741^{\prime} \mathrm{N}$

Longitude: $152^{\circ} 08.568^{\prime} \mathrm{W}$

Elevation: 201 meters above mean sea level

Installation date: 20 AUG 1998

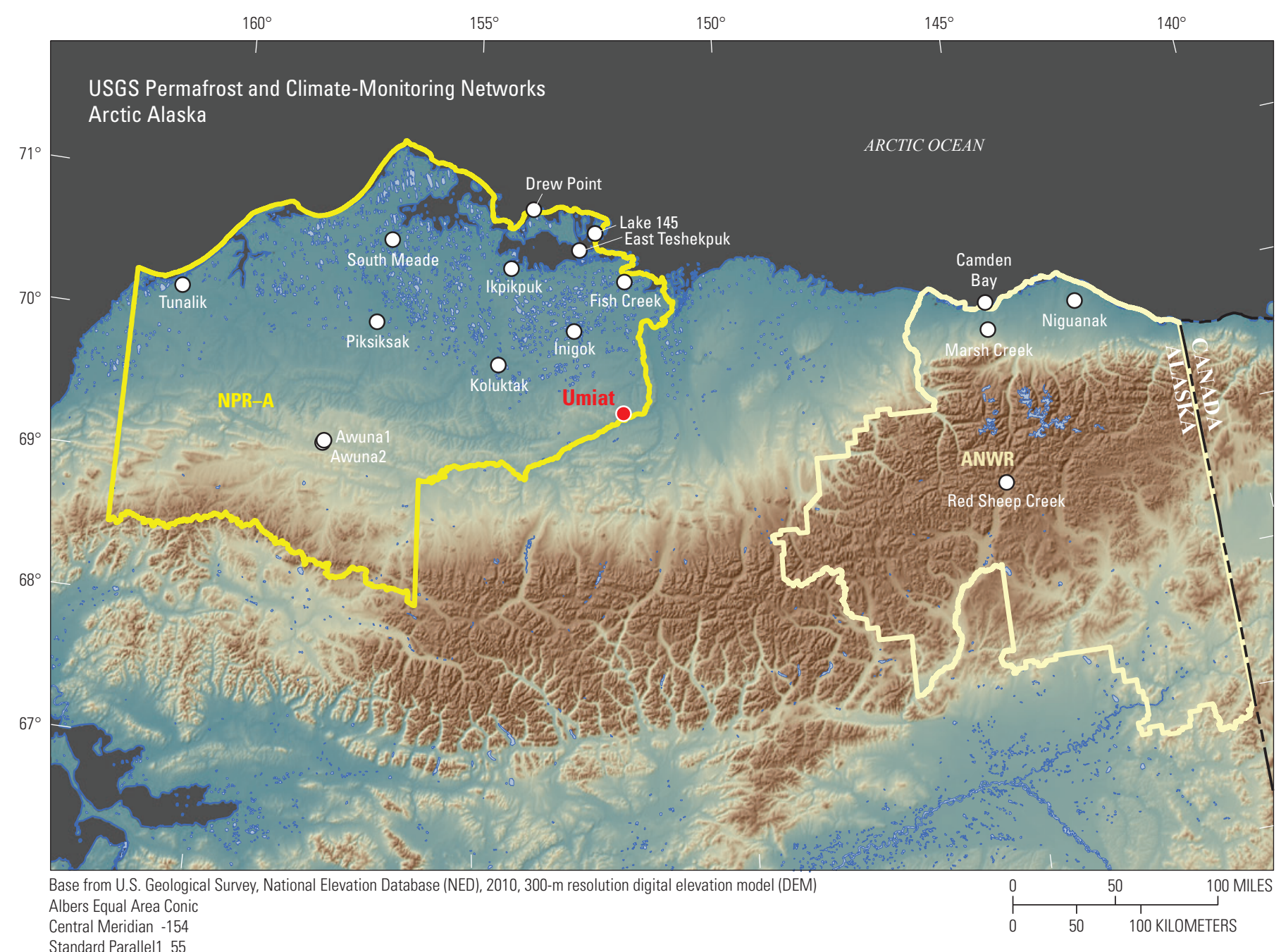

Standard Parallel1 55

Standard Parallel2 65

Figure F-1. Location map presenting the specific location of the Umiat site and its spatial relation to other sites in the monitoring network. (NPR-A, National Petroleum Reserve-Alaska; ANWR, Arctic National Wildlife Refuge) 


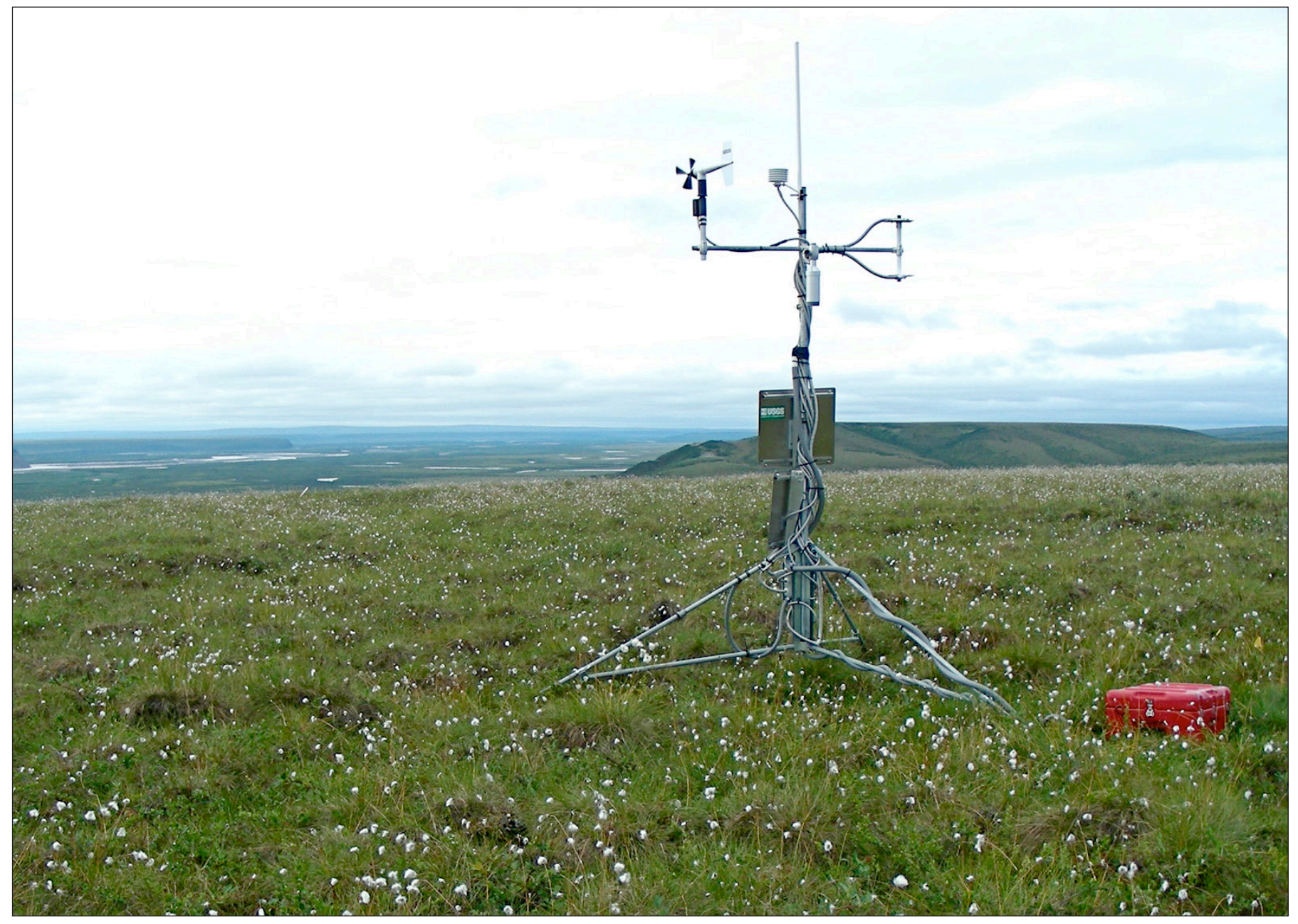

Figure F-2. Umiat station in summer 2008. 
Umiat Windroses
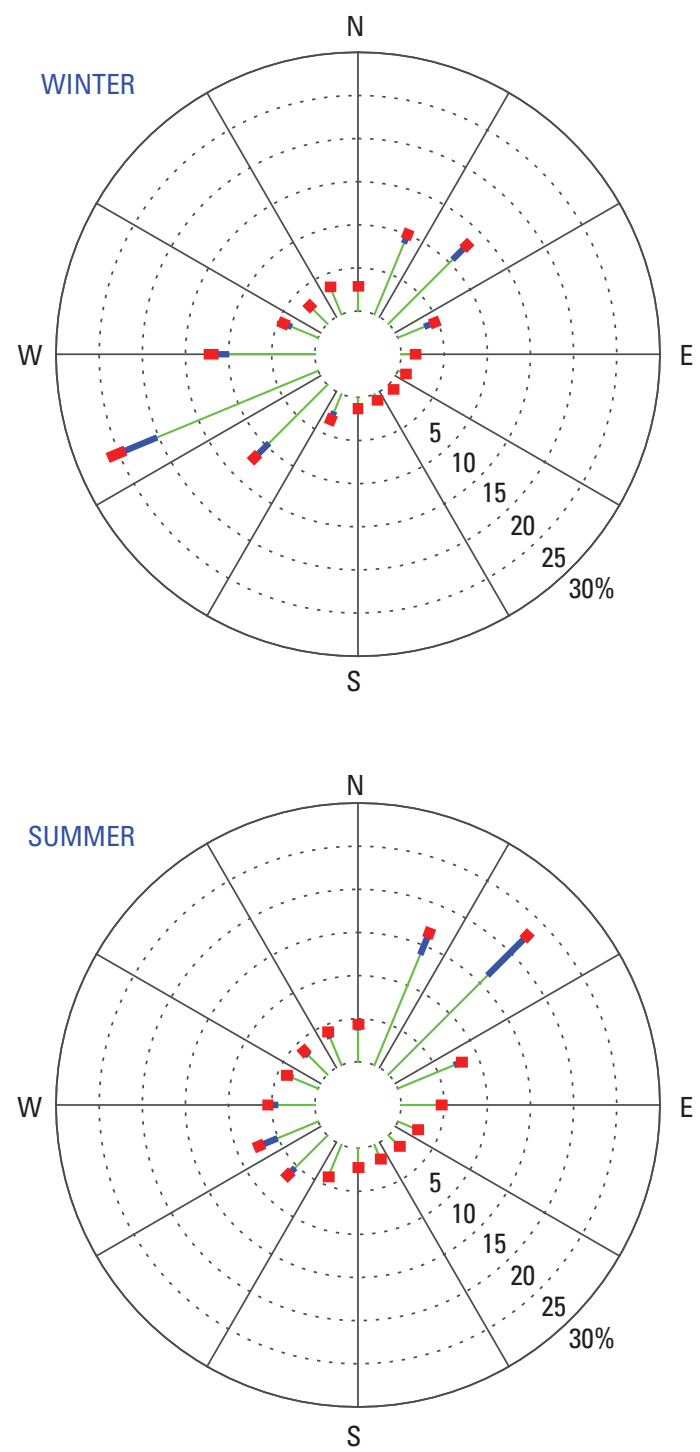

EXPLANATION

Wind speed $(\mathrm{m} / \mathrm{s}$

$0.5<\mathrm{U}<5$

$5<\mathrm{U}<10$

$\mathrm{U}>10$

Figure F-3. Umiat seasonal windroses. The wind direction and speed data are divided into 16 wind direction categories $\left(22.5^{\circ}\right.$ each) and 3 wind speed classes: less than $5 \mathrm{~m} / \mathrm{s}$, between $5 \mathrm{~m} / \mathrm{s}$ and $10 \mathrm{~m} / \mathrm{s}$, and greater than $10 \mathrm{~m} / \mathrm{s}$. The percentage of time that wind speeds occupy each class and directional category (concentric rings) is presented for each season: winter (December, January, February), spring (March, April, May), summer (June, July, August), and autumn (September, October, November). (m/s, meters per second; U, wind speed; N, north; E, east; S, south; W, west)

\section{Data Access}

List of station data ScienceBase data release files and summary tables for this report are available at https://doi.org/10.5066/F7VX0FGB. 


\section{G. Tunalik}

GTN-P code: U25

Latitude: $70^{\circ} 11.756{ }^{\prime} \mathrm{N}$

Longitude: $161^{\circ} 04.687^{\prime} \mathrm{W}$

Elevation: 26 meters above mean sea level

Installation date: 20 AUG 1998

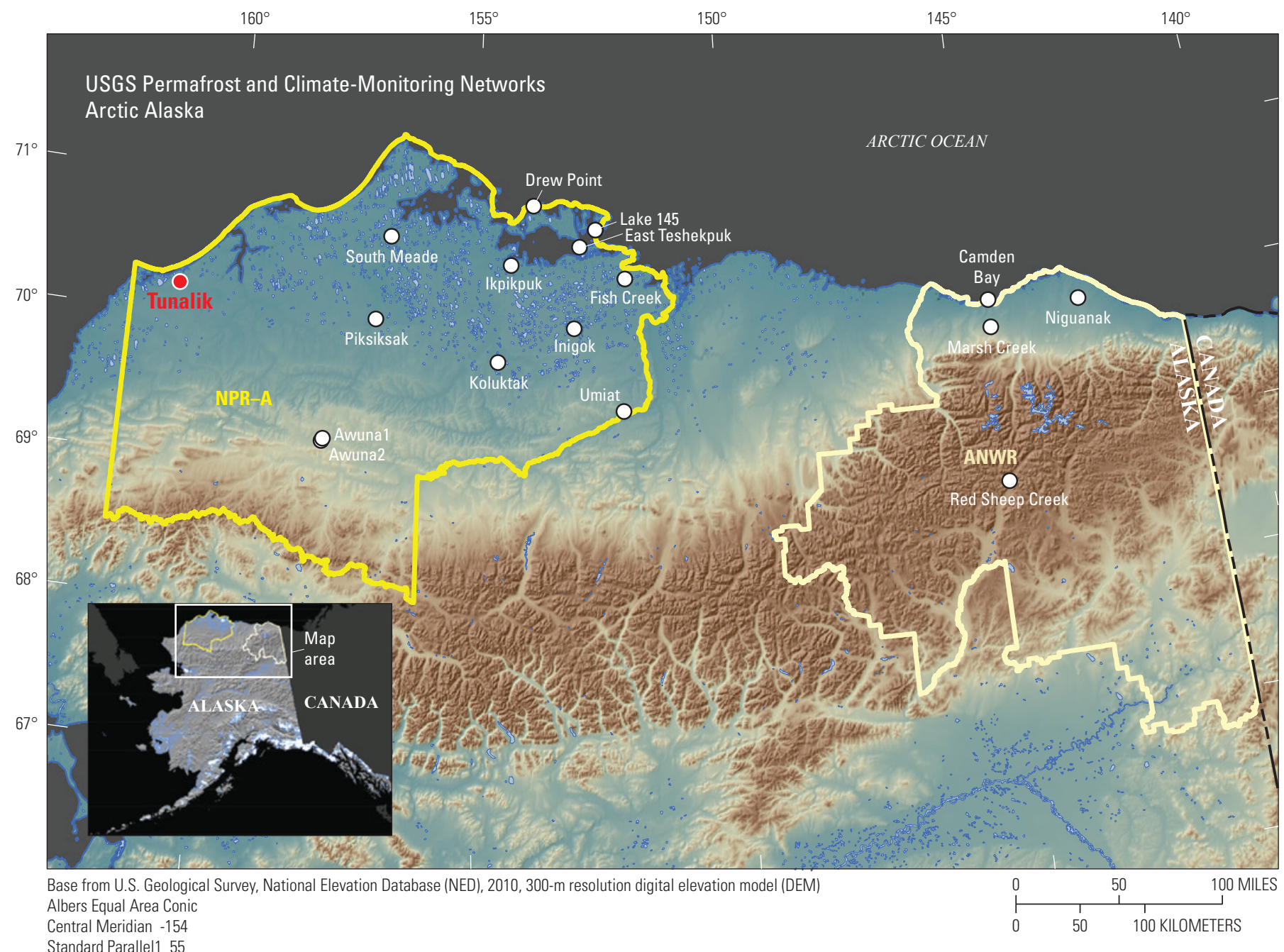

Central Meridian -15

Standard Parallel1 55

Figure G-1. Location map presenting the specific location of the Tunalik site and its spatial relation to other sites in the monitoring network. (NPR-A, National Petroleum Reserve-Alaska; ANWR, Arctic National Wildlife Refuge) 


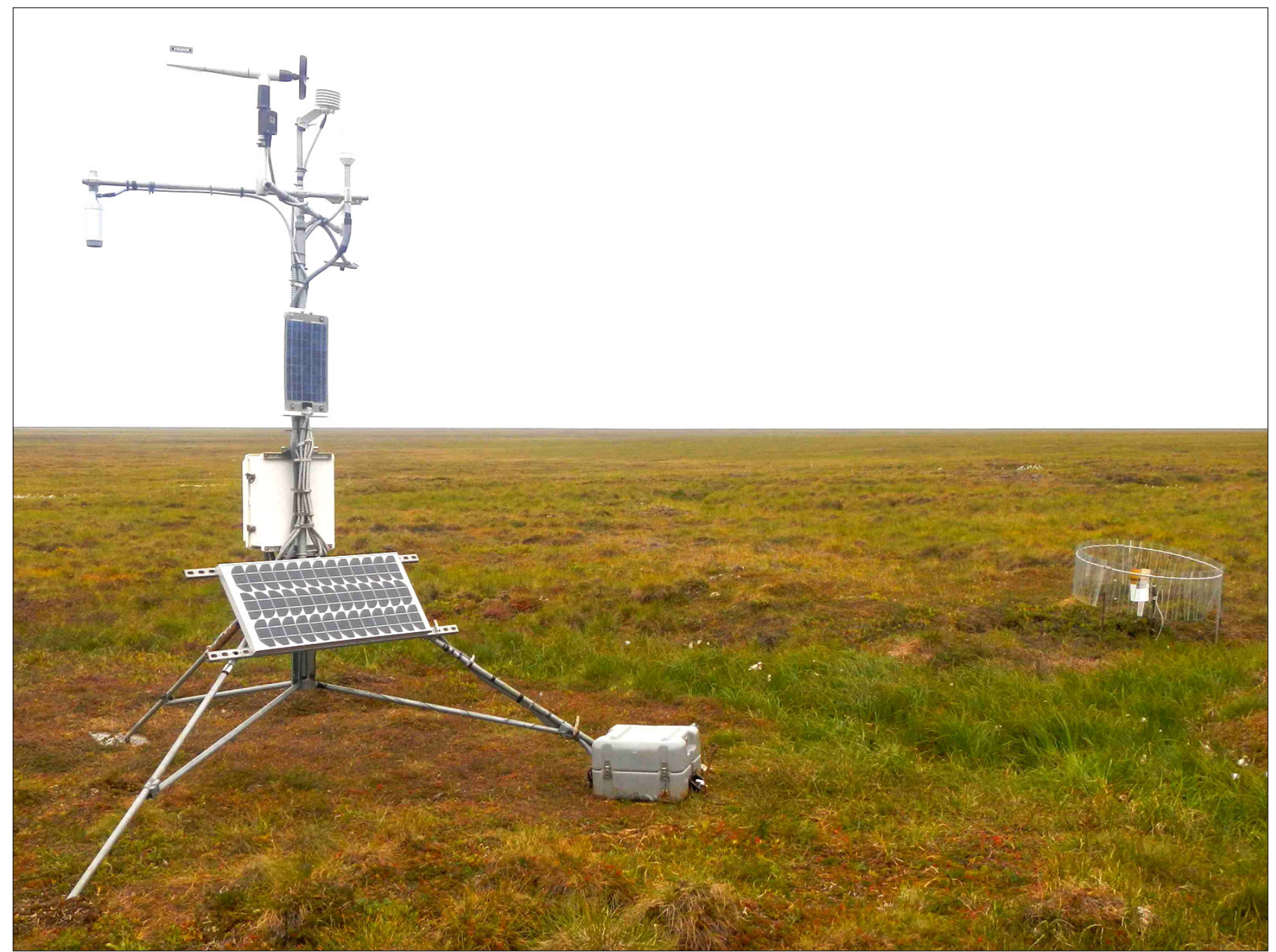

Figure G-2. Tunalik station in summer 2008. 
Tunalik Windroses
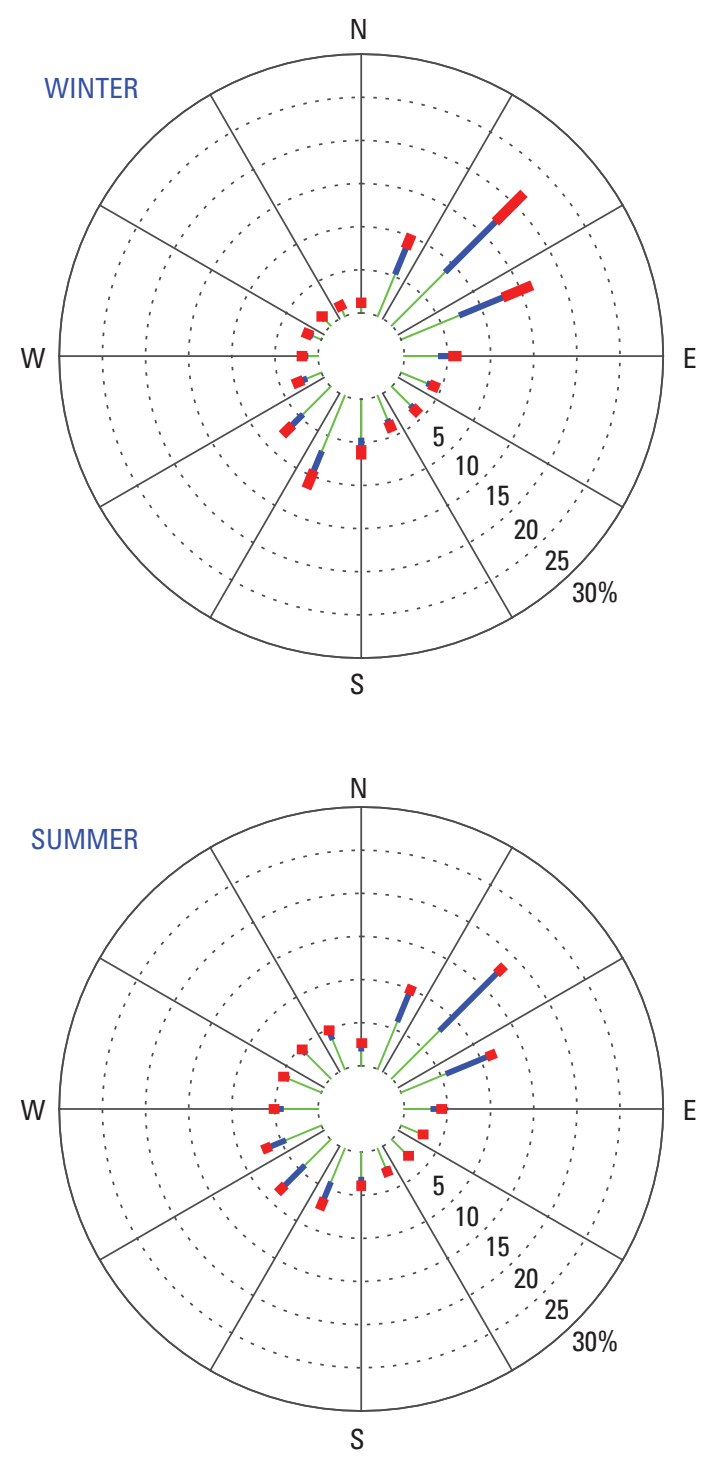
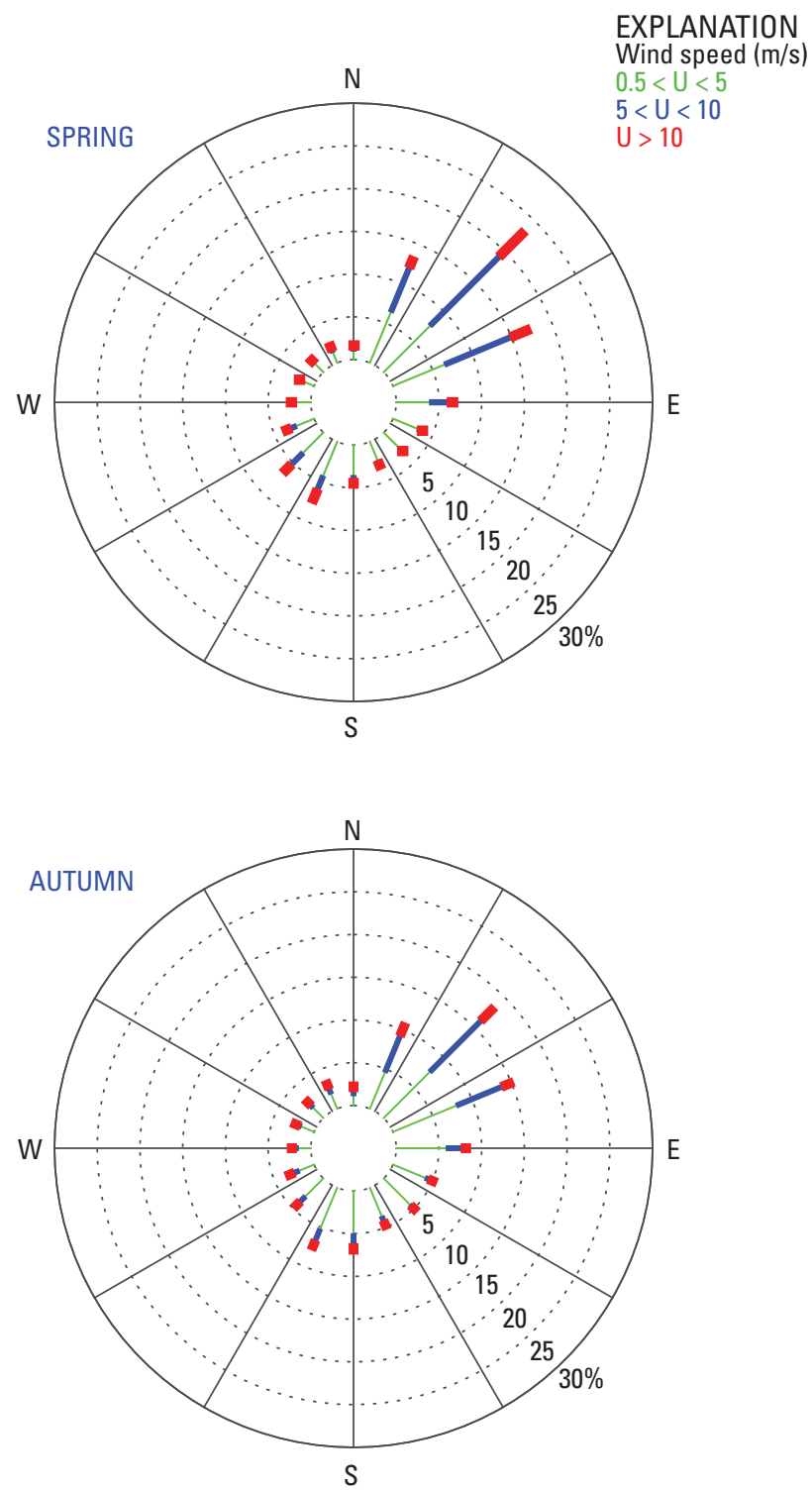

Figure G-3. Tunalik seasonal windroses. The wind direction and speed data are divided into 16 wind direction categories $\left(22.5^{\circ}\right.$ each) and 3 wind speed classes: less than $5 \mathrm{~m} / \mathrm{s}$, between $5 \mathrm{~m} / \mathrm{s}$ and $10 \mathrm{~m} / \mathrm{s}$, and greater than $10 \mathrm{~m} / \mathrm{s}$. The percentage of time that wind speeds occupy each class and directional category (concentric rings) is presented for each season: winter (December, January, February), spring (March, April, May), summer (June, July, August), and autumn (September, October, November). (m/s, meters per second; $U$, wind speed; $N$, north; $E$, east; $S$, south; $W$, west)

Data Access

List of station data ScienceBase data release files and summary tables for this report are available at https://doi.org/10.5066/F7VX0FGB. 


\section{H. Koluktak}

GTN-P code: U30

Latitude: $69^{\circ} 45.096^{\prime} \mathrm{N}$

Longitude: $154^{\circ} 37.054^{\prime} \mathrm{W}$

Elevation: 60 meters above mean sea level

Installation date: 27 AUG 1999

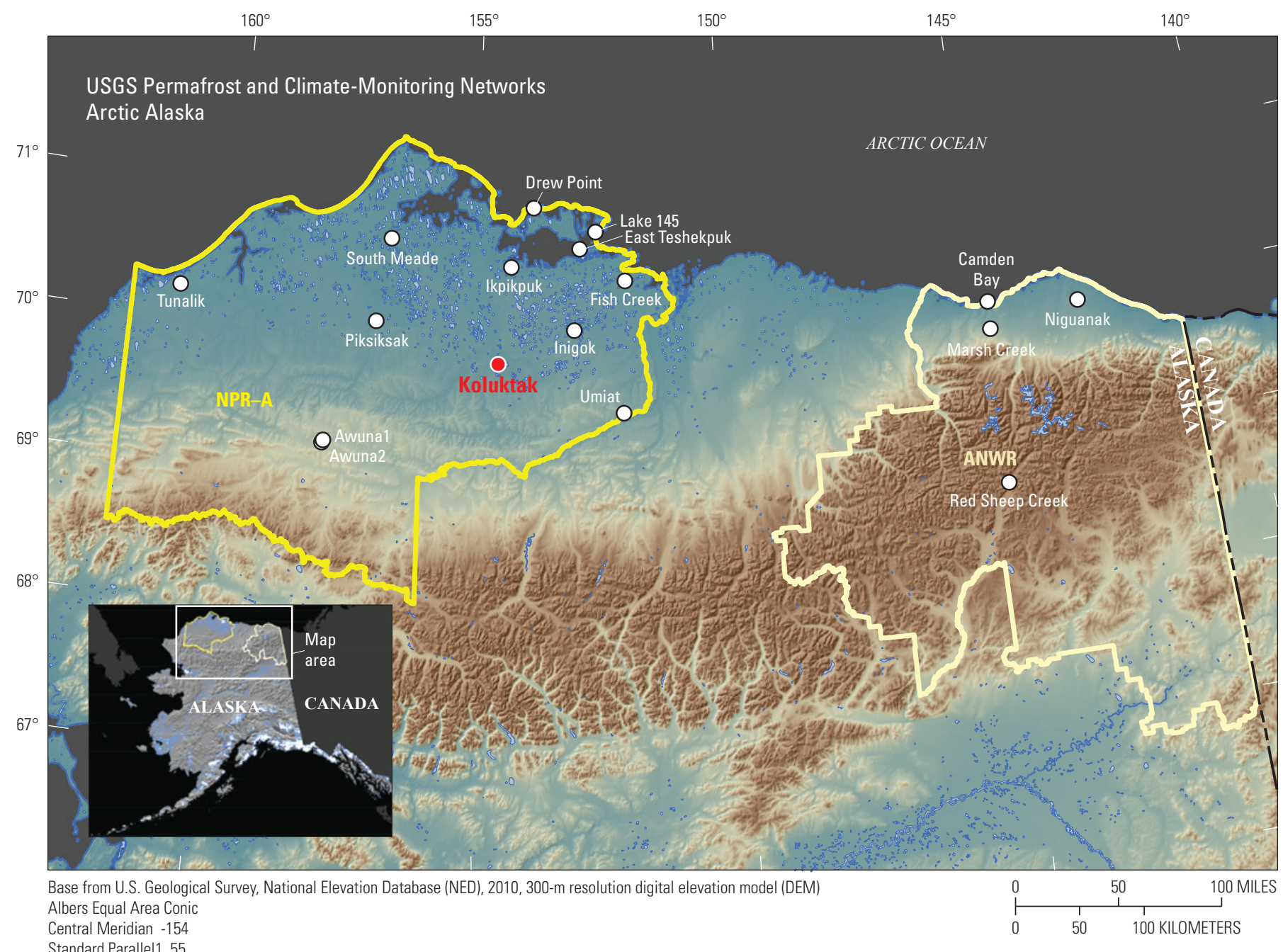

Standard Parallel1 55

Figure H-1. Location map presenting the specific location of the Koluktak site and its spatial relation to other sites in the monitoring network. (NPR-A, National Petroleum Reserve-Alaska; ANWR, Arctic National Wildlife Refuge) 


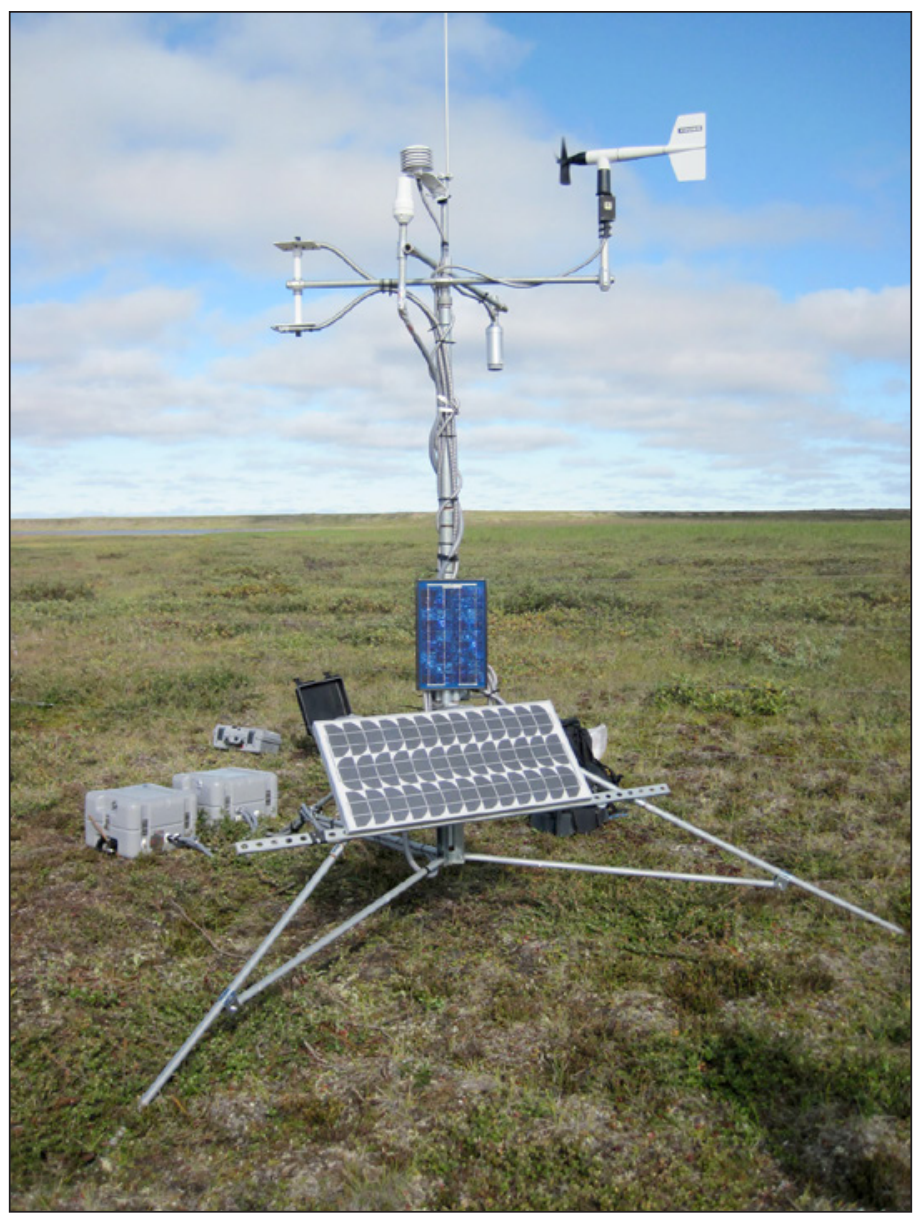

Figure H-2. Koluktak station in summer 2008. 
Koluktak Windroses
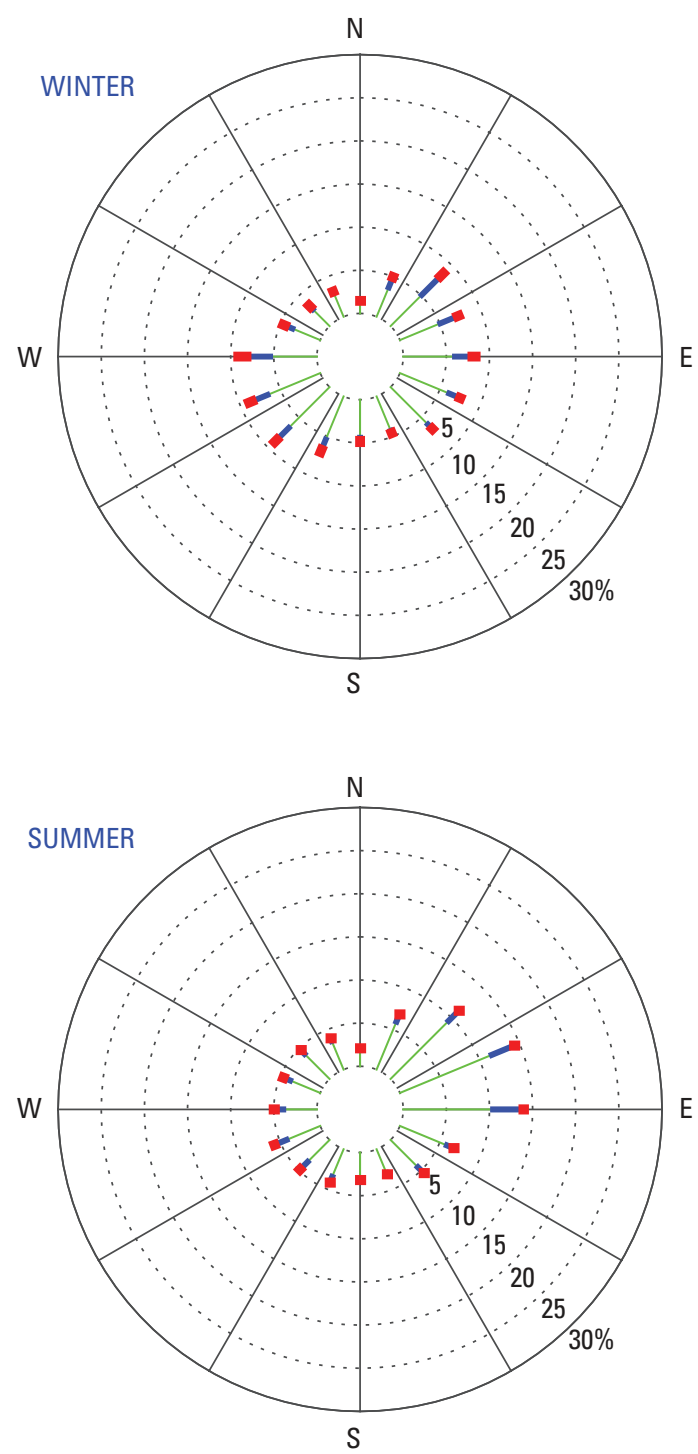
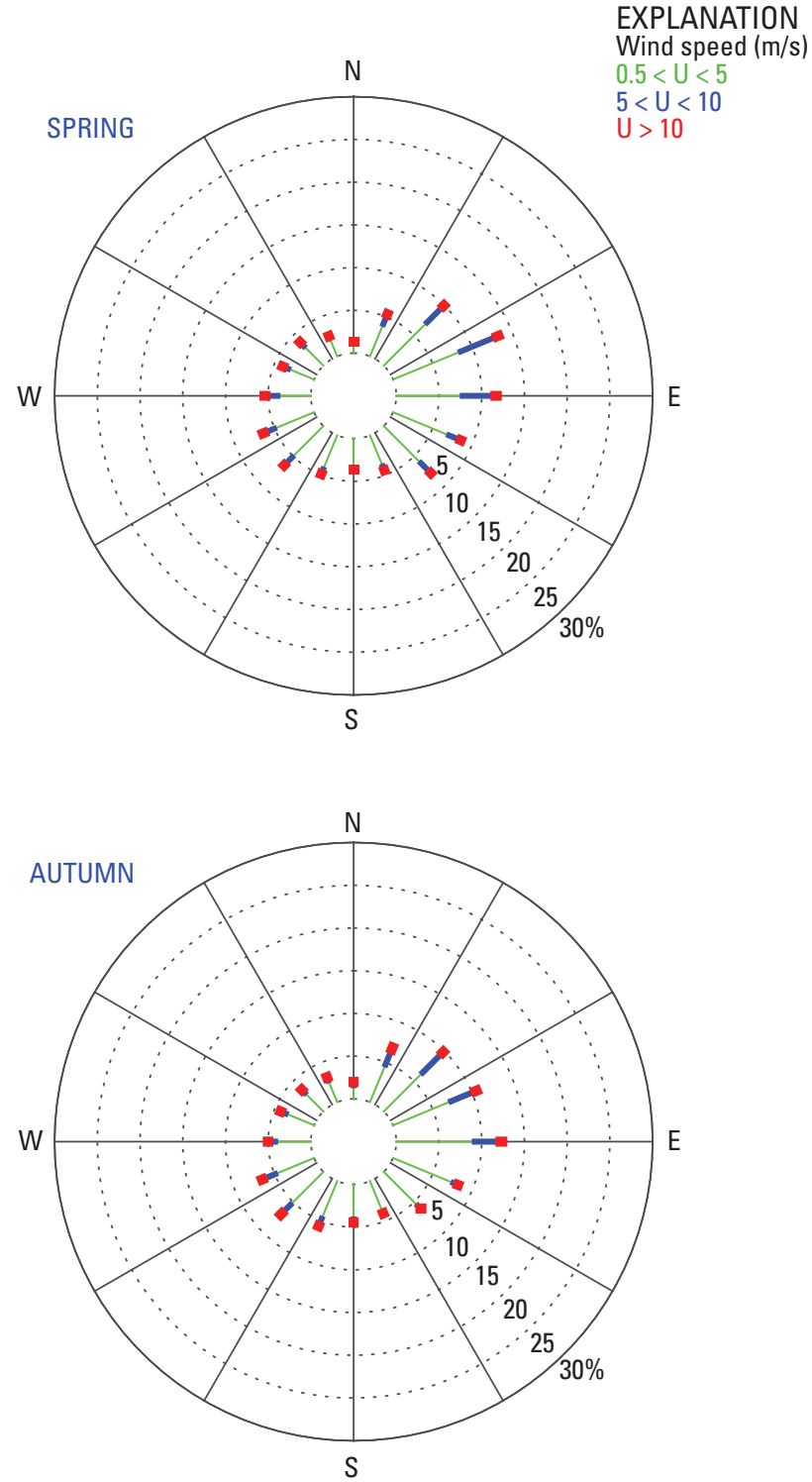

Figure H-3. Koluktak seasonal windroses. The wind direction and speed data are divided into 16 wind direction categories $\left(22.5^{\circ}\right.$ each) and 3 wind speed classes: less than $5 \mathrm{~m} / \mathrm{s}$, between $5 \mathrm{~m} / \mathrm{s}$ and $10 \mathrm{~m} / \mathrm{s}$, and greater than $10 \mathrm{~m} / \mathrm{s}$. The percentage of time that wind speeds occupy each class and directional category (concentric rings) is presented for each season: winter (December, January, February), spring (March, April, May), summer (June, July, August), and autumn (September, October, November). (m/s, meters per second; U, wind speed; N, north; E, east; S, south; W, west)

\section{Data Access}

List of station data ScienceBase data release files and summary tables for this report are available at https://doi.org/10.5066/F7VX0FGB. 


\section{South Meade}

GTN-P code: U33

Latitude: $70^{\circ} 37.708^{\prime} \mathrm{N}$

Longitude: $156^{\circ} 50.119^{\prime} \mathrm{W}$

Elevation: 15 meters above mean sea level

Installation date: 08 AUG 2003

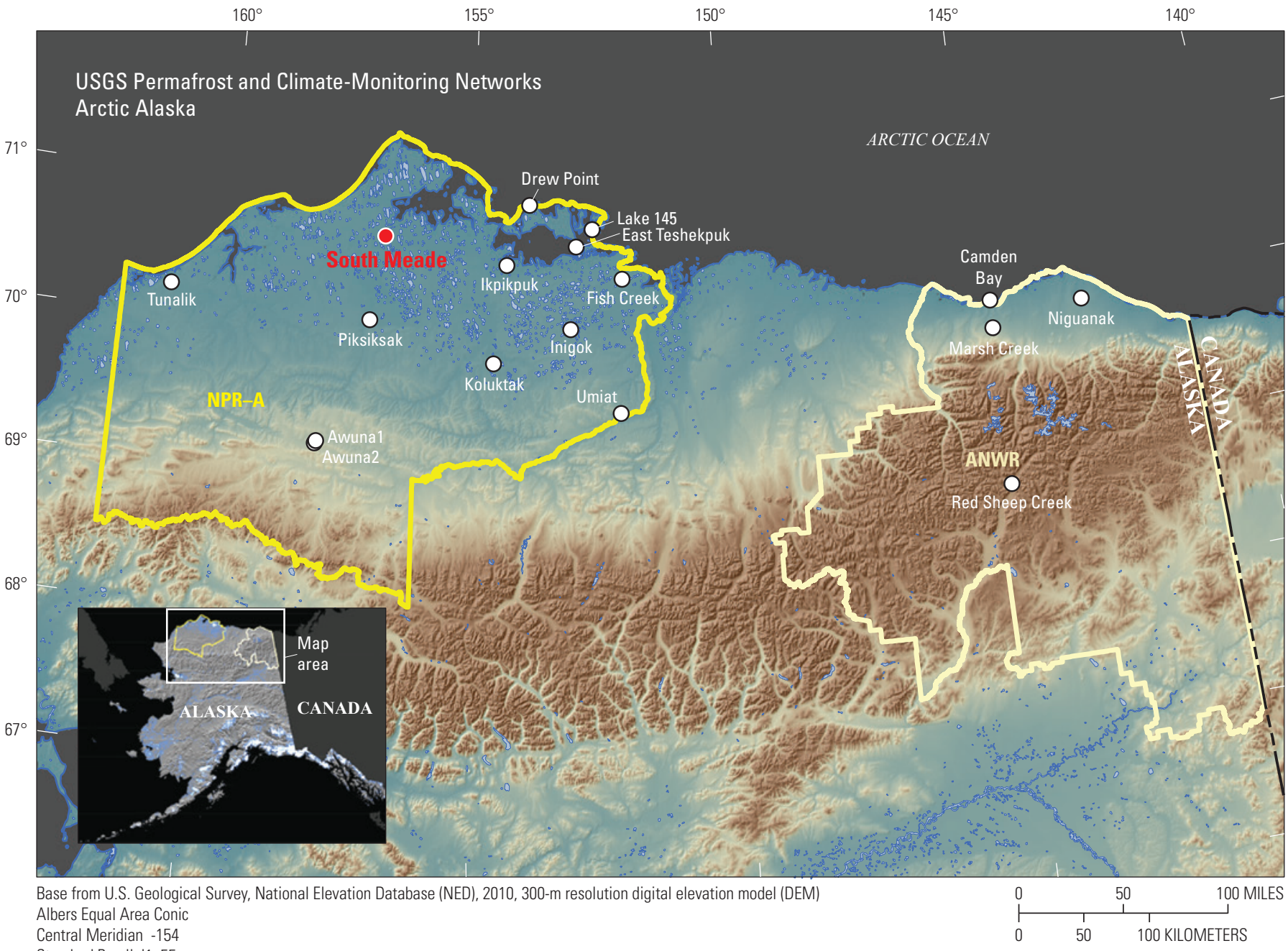

Central Meridian -154

Standard Parallel1 55

Standard Parallel2 65

Figure I-1. Location map presenting the specific location of the South Meade site and its spatial relation to other sites in the monitoring network. (NPR-A, National Petroleum Reserve-Alaska; ANWR, Arctic National Wildlife Refuge) 


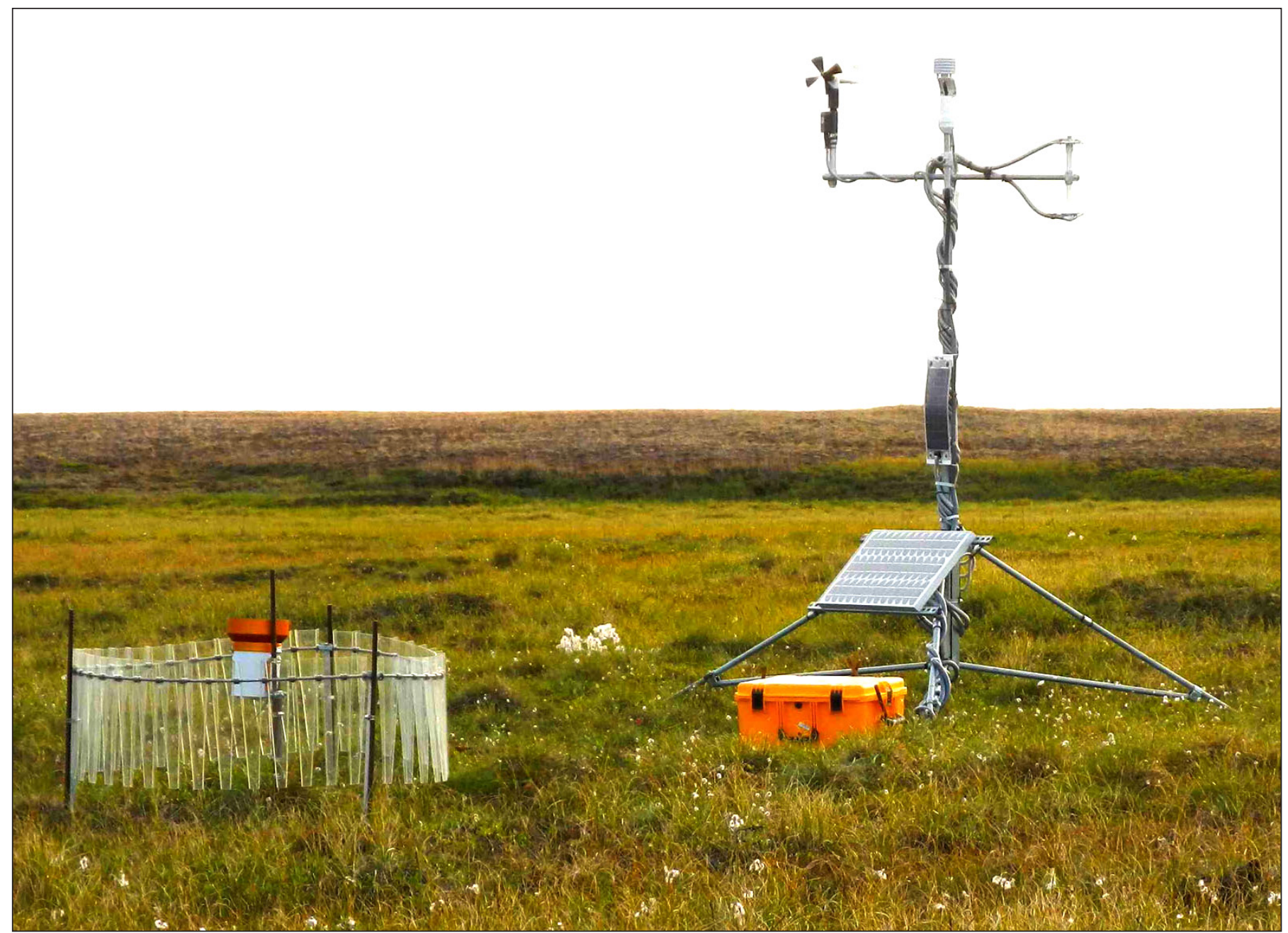

Figure I-2. South Meade station in summer 2008. 
South Meade Windroses
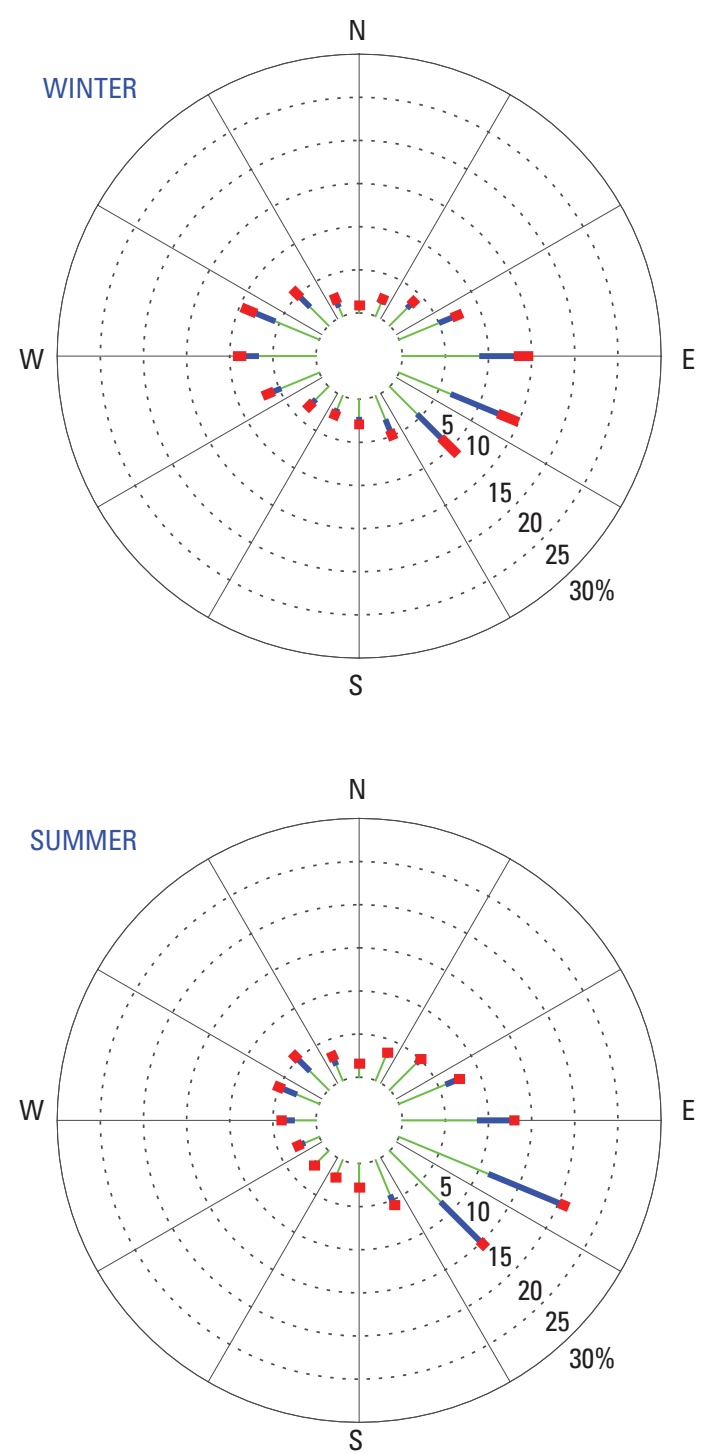
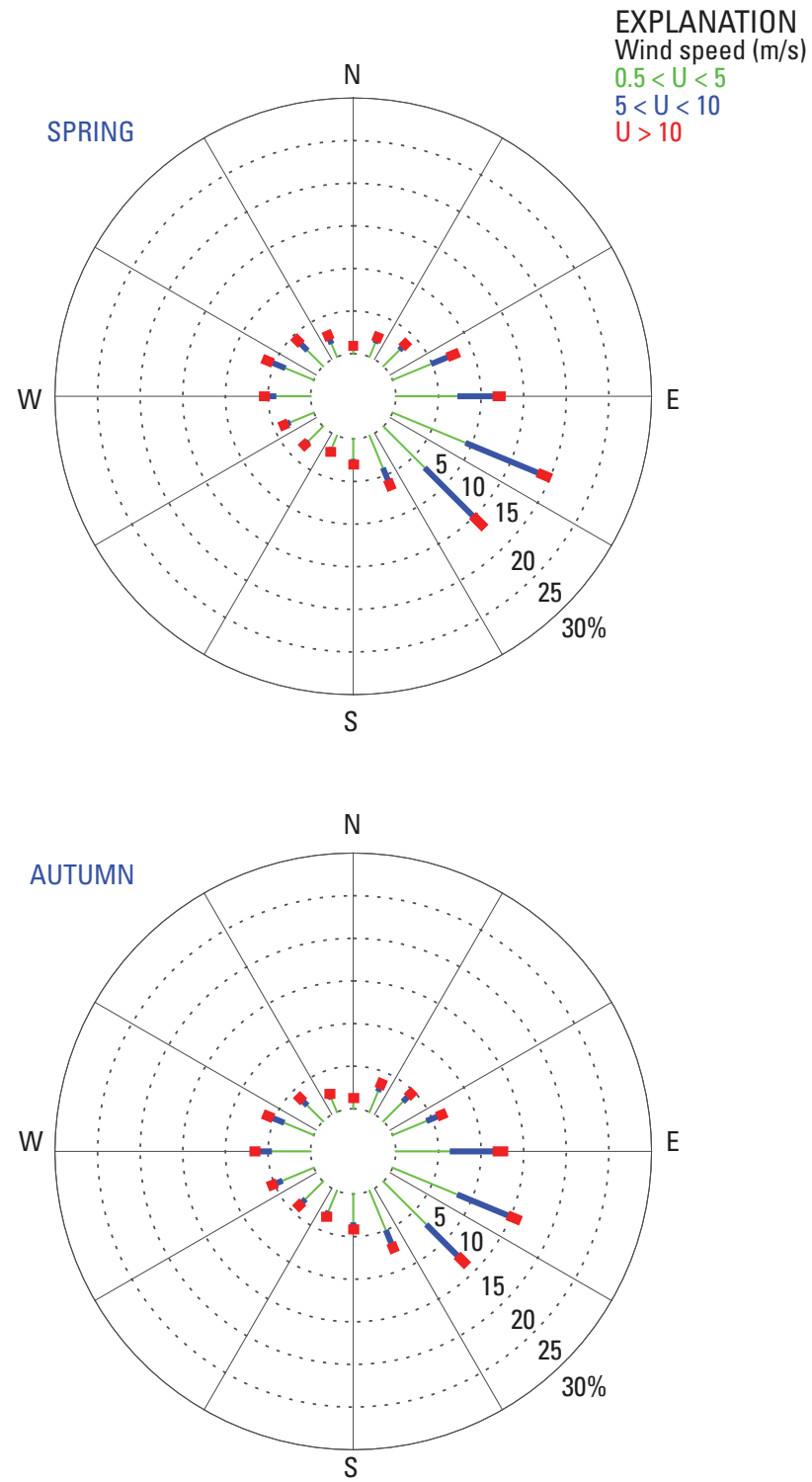

Figure I-3. South Meade seasonal windroses. The wind direction and speed data are divided into 16 wind direction categories $\left(22.5^{\circ}\right.$ each) and 3 wind speed classes: less than $5 \mathrm{~m} / \mathrm{s}$, between $5 \mathrm{~m} / \mathrm{s}$ and $10 \mathrm{~m} / \mathrm{s}$, and greater than $10 \mathrm{~m} / \mathrm{s}$. The percentage of time that wind speeds occupy each class and directional category (concentric rings) is presented for each season: winter (December, January, February), spring (March, April, May), summer (June, July, August), and autumn (September, October, November). (m/s, meters per second; U, wind speed; N, north; E, east; S, south; W, west)

Data Access

List of station data ScienceBase data release files and summary tables for this report are available at https://doi.org/10.5066/F7VX0FGB. 


\section{J. Awuna2}

GTN-P code: U35

Latitude: $69^{\circ} 09.3311^{\prime} \mathrm{N}$

Longitude: $158^{\circ} 01.827^{\prime} \mathrm{W}$

Elevation: 343 meters above mean sea level

Installation date: 22 AUG 2003

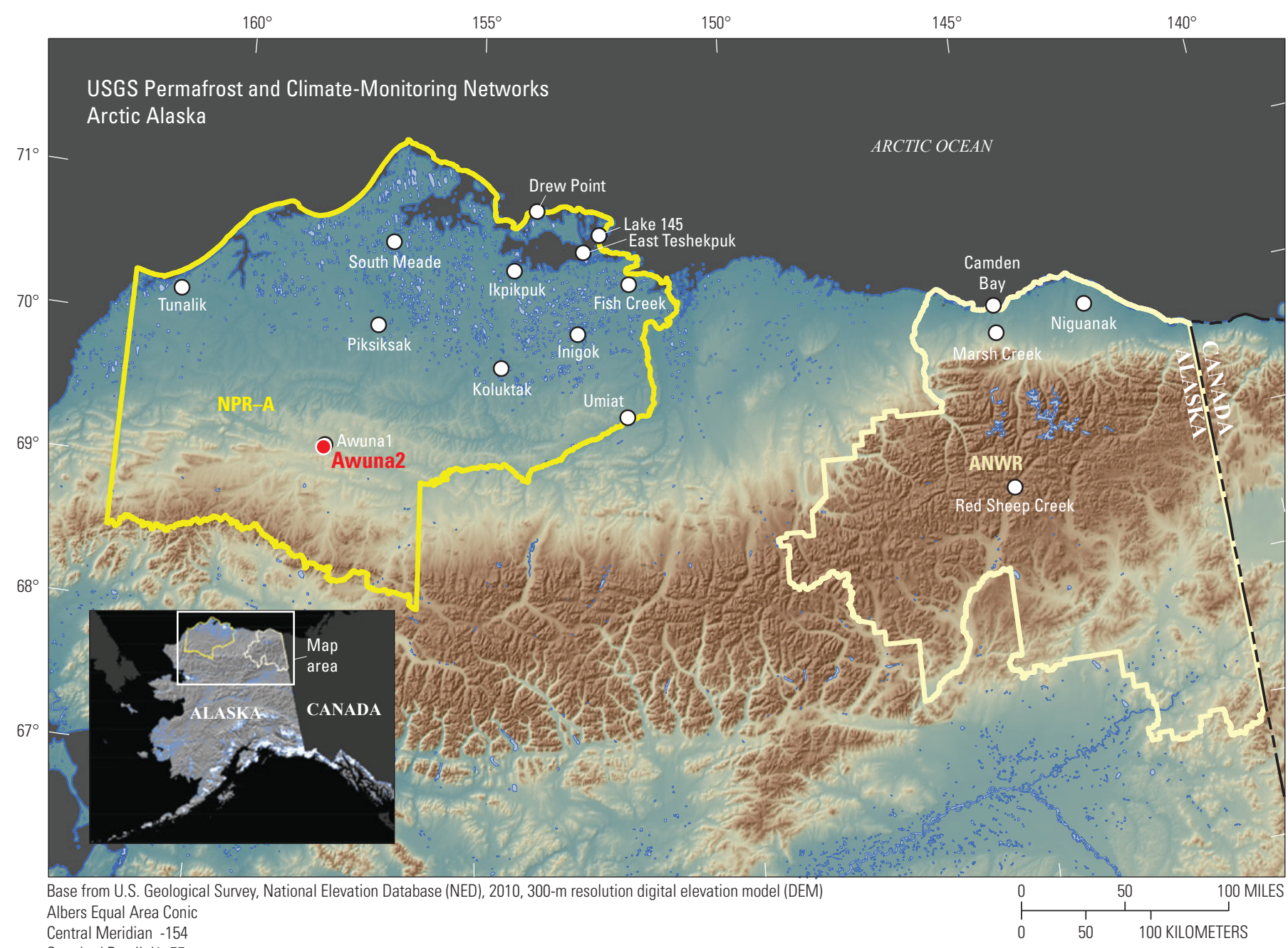

(1)

Figure J-1. Location map presenting the specific location of the Awuna2 site and its spatial relation to other sites in the monitoring network. (NPR-A, National Petroleum Reserve-Alaska; ANWR, Arctic National Wildlife Refuge) 


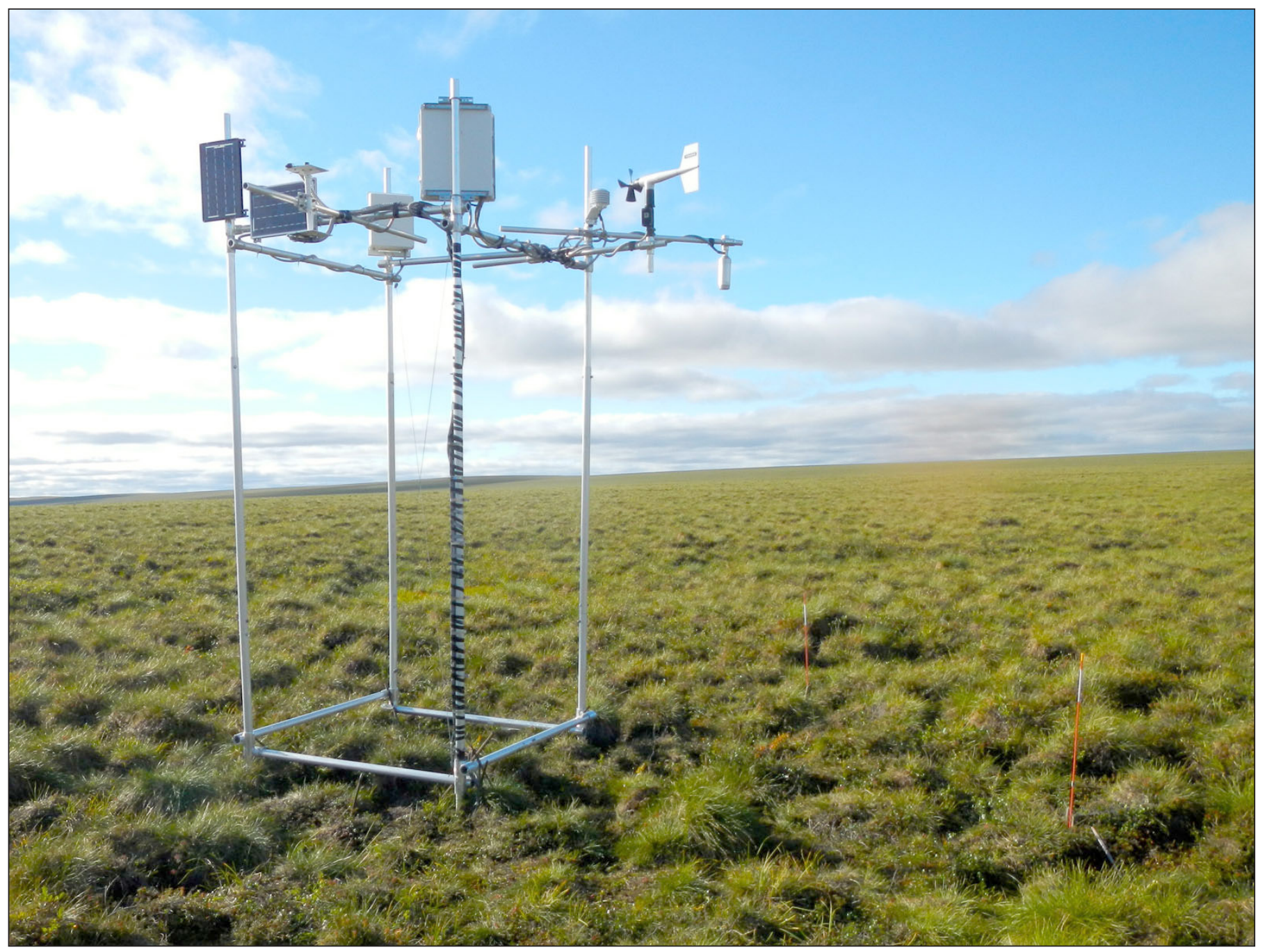

Figure J-2. Awuna2 station in summer 2008. 
Awuna2 Windroses
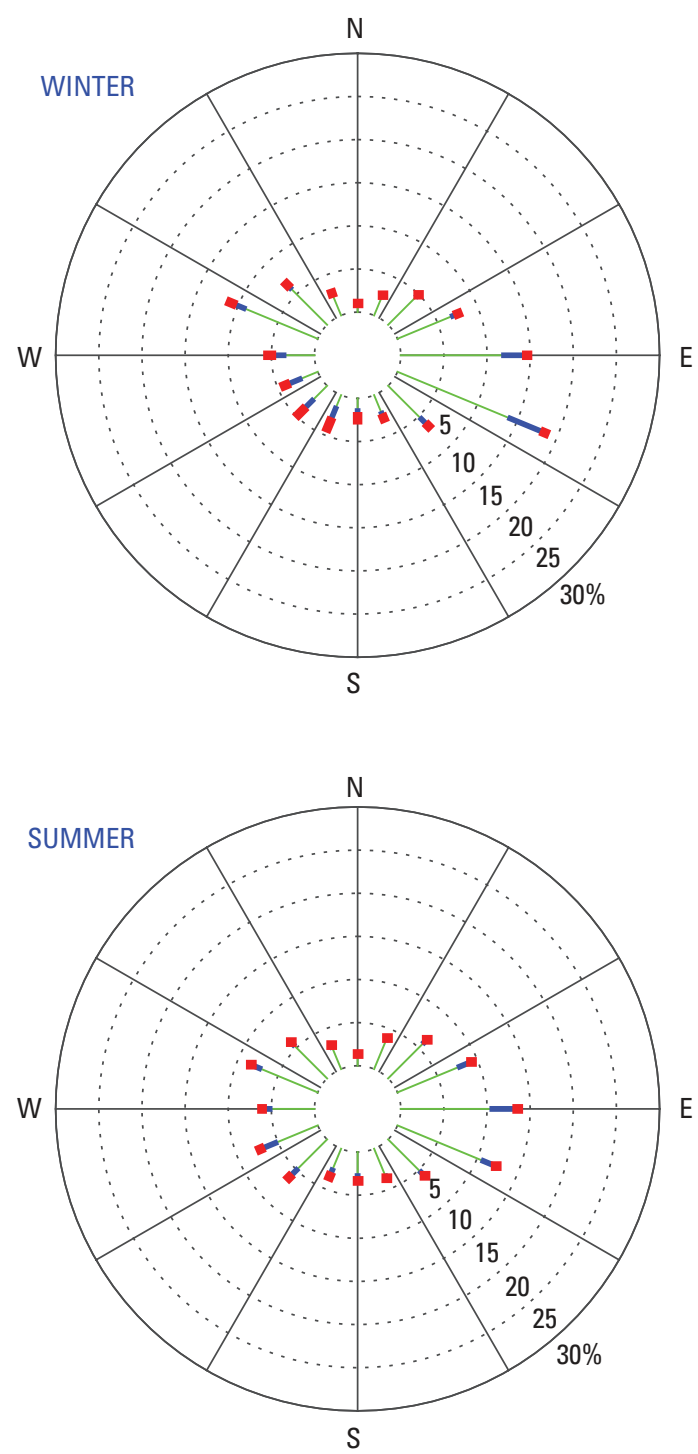
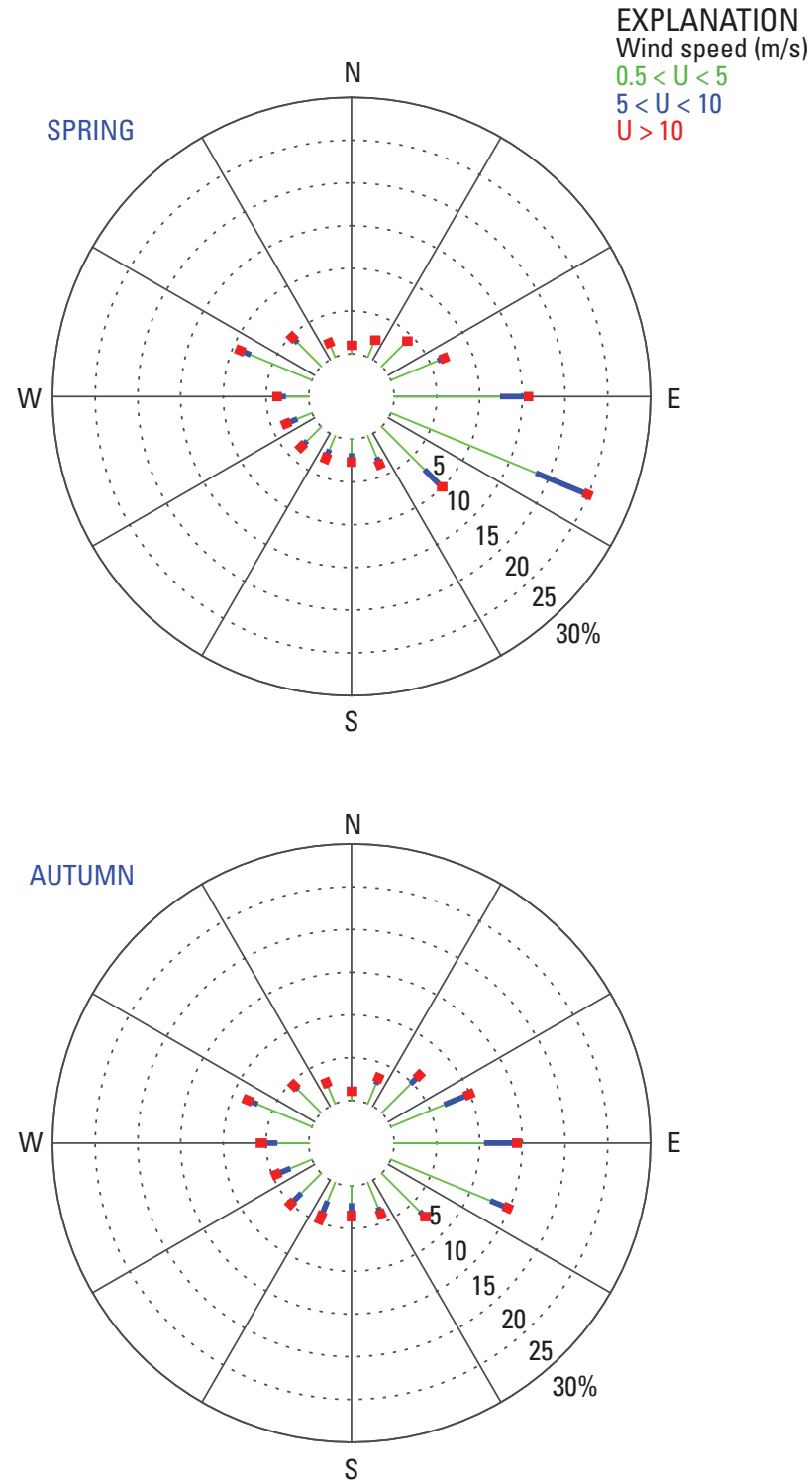

Figure J-3. Awuna2 seasonal windroses. The wind direction and speed data are divided into 16 wind direction categories $\left(22.5^{\circ}\right.$ each) and 3 wind speed classes: less than $5 \mathrm{~m} / \mathrm{s}$, between $5 \mathrm{~m} / \mathrm{s}$ and $10 \mathrm{~m} / \mathrm{s}$, and greater than $10 \mathrm{~m} / \mathrm{s}$. The percentage of time that wind speeds occupy each class and directional category (concentric rings) is presented for each season: winter (December, January, February), spring (March, April, May), summer (June, July, August), and autumn (September, October, November). (m/s, meters per second; U, wind speed; $N$, north; $E$, east; $S$, south; W, west)

\section{Data Access}

List of station data ScienceBase data release files and summary tables for this report are available at https://doi.org/10.5066/F7VX0FGB. 


\section{K. Piksiksak}

GTN-P code: U37

Latitude: $70^{\circ} 02.197^{\prime} \mathrm{N}$

Longitude: $157^{\circ} 04.882^{\prime} \mathrm{W}$

Elevation: 33 meters above mean sea level

Installation date: 08 AUG 2004

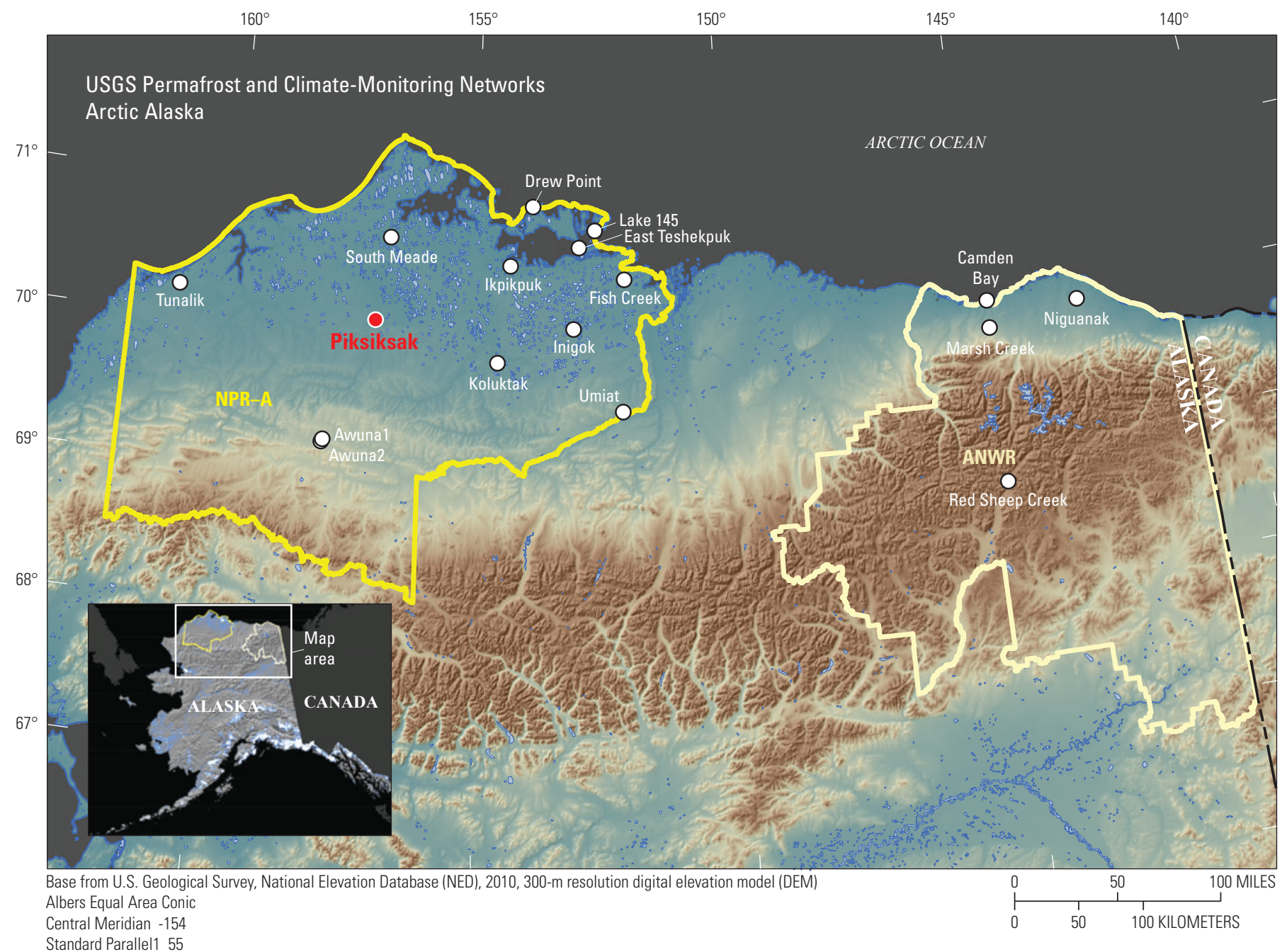

Standard Parc

Standard Parallel2 65

Figure K-1. Location map presenting the specific location of the Piksiksak site and its spatial relation to other sites in the monitoring network. (NPR-A, National Petroleum Reserve-Alaska; ANWR, Arctic National Wildlife Refuge) 


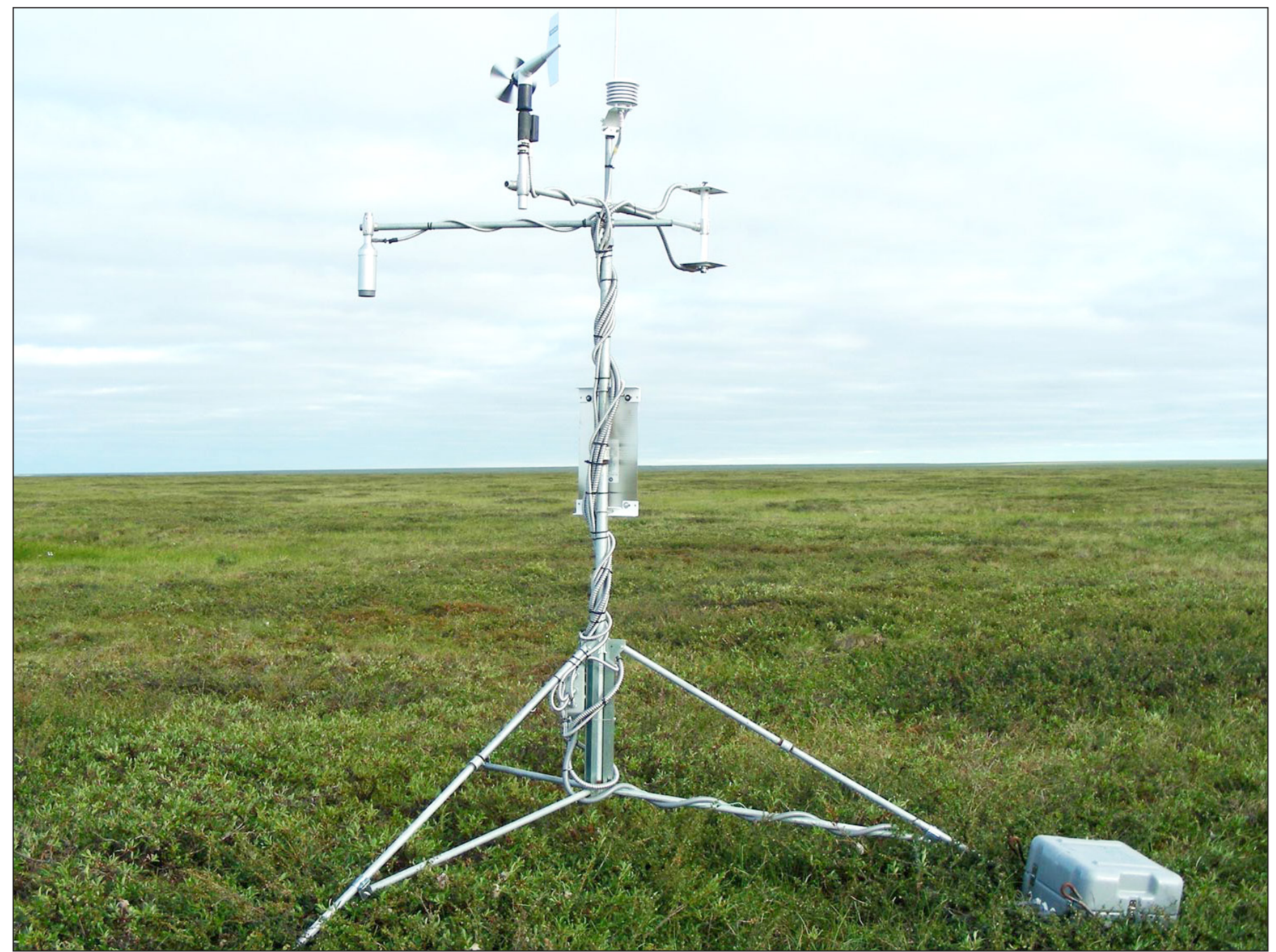

Figure K-2. Piksiksak station in summer 2008. 
Piksiksak Windroses
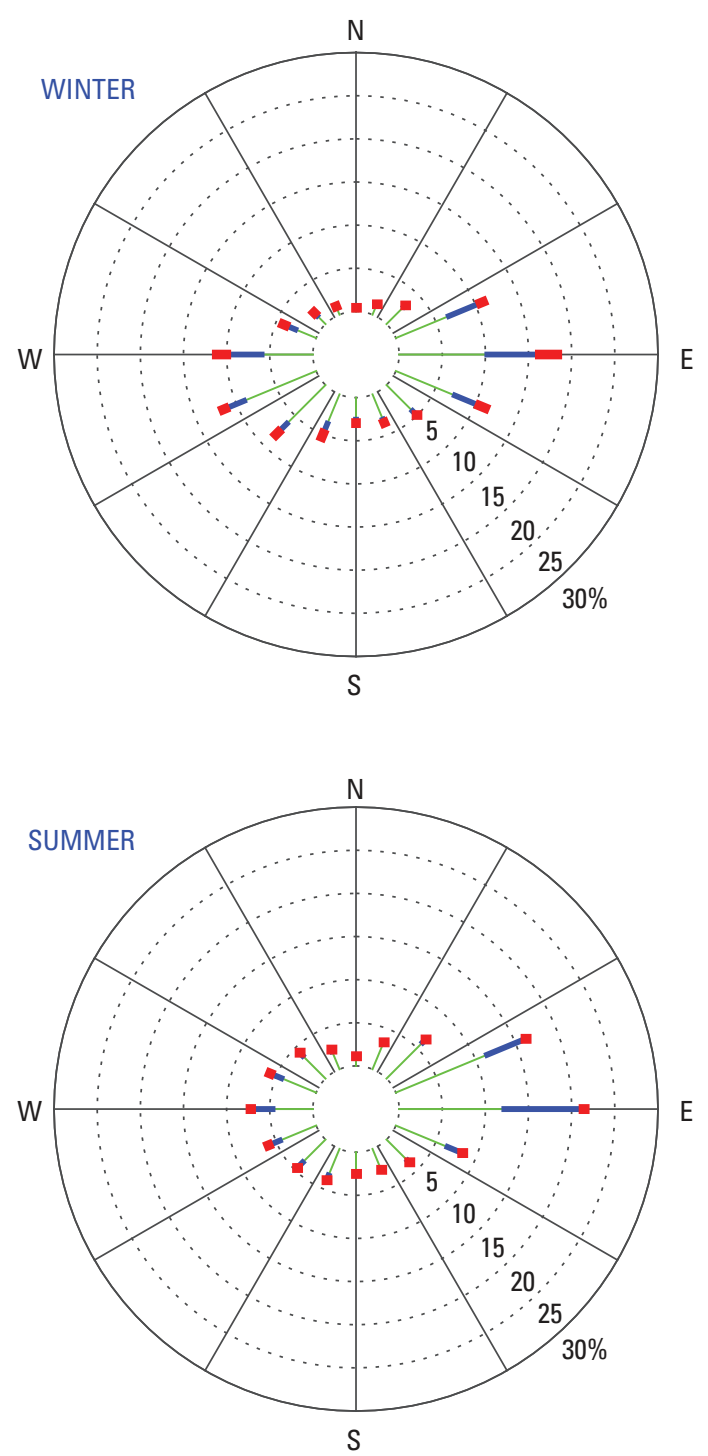

EXPLANATION

Wind speed $(\mathrm{m} / \mathrm{s})$

$0.5<U<5$

$5<\mathrm{U}<10$
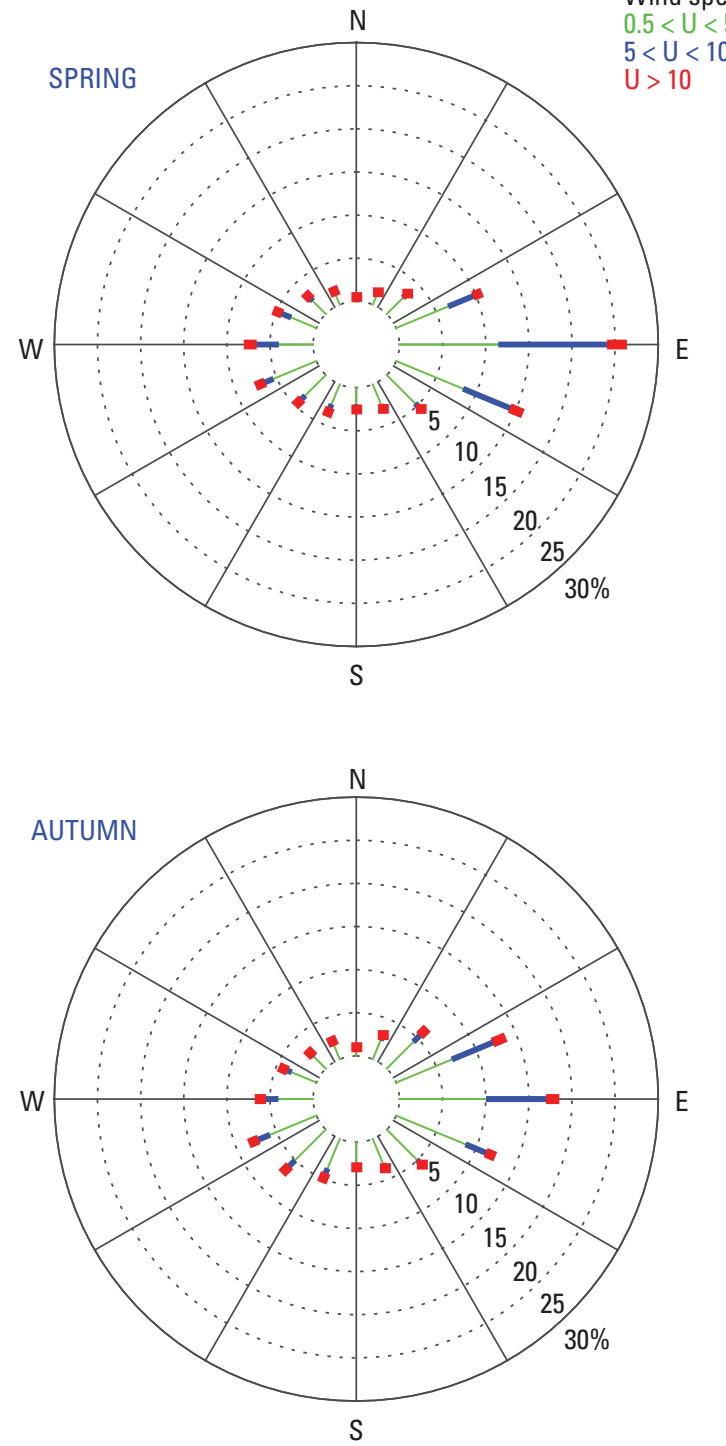

Figure K-3. Piksiksak seasonal windroses. The wind direction and speed data are divided into 16 wind direction categories $\left(22.5^{\circ}\right.$ each) and 3 wind speed classes: less than $5 \mathrm{~m} / \mathrm{s}$, between $5 \mathrm{~m} / \mathrm{s}$ and $10 \mathrm{~m} / \mathrm{s}$, and greater than $10 \mathrm{~m} / \mathrm{s}$. The percentage of time that wind speeds occupy each class and directional category (concentric rings) is presented for each season: winter (December, January, February), spring (March, April, May), summer (June, July, August), and autumn (September, October, November). (m/s, meters per second; U, wind speed; $\mathrm{N}$, north; E, east; $\mathrm{S}$, south; W, west)

Data Access

List of station data ScienceBase data release files and summary tables for this report are available at https://doi.org/10.5066/F7VX0FGB. 


\section{East Teshekpuk}

GTN-P code: U38

Latitude: $70^{\circ} 34.111^{\prime} \mathrm{N}$

Longitude: $152^{\circ} 57.899^{\prime} \mathrm{W}$

Elevation: 7 meters above mean sea level

Installation date: 10 AUG 2004

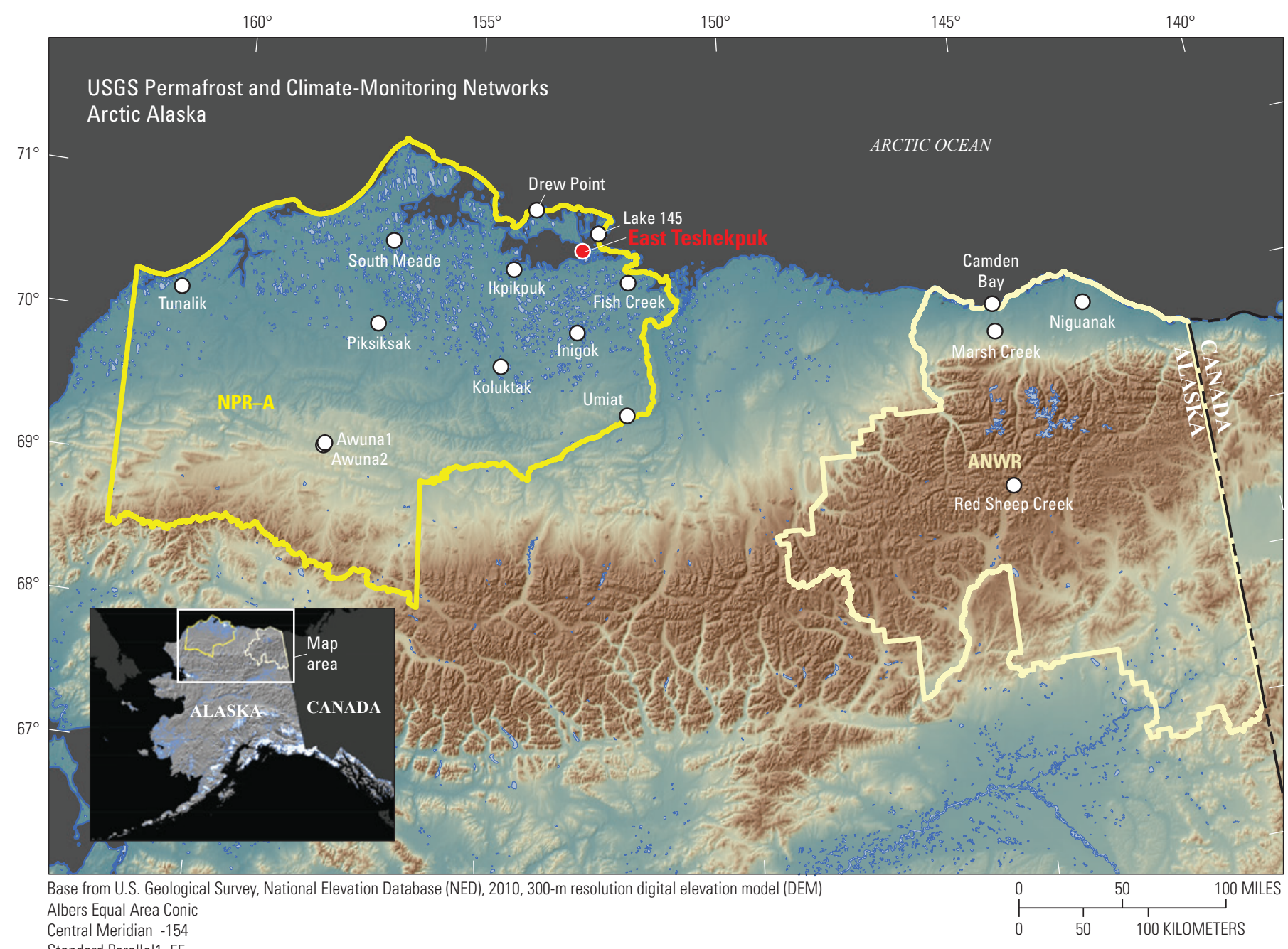

(t) Meridian -154

Standard Parallel2 65

Figure L-1. Location map presenting the specific location of the East Teshekpuk site and its spatial relation to other sites in the monitoring network. (NPR-A, National Petroleum Reserve-Alaska; ANWR, Arctic National Wildlife Refuge) 


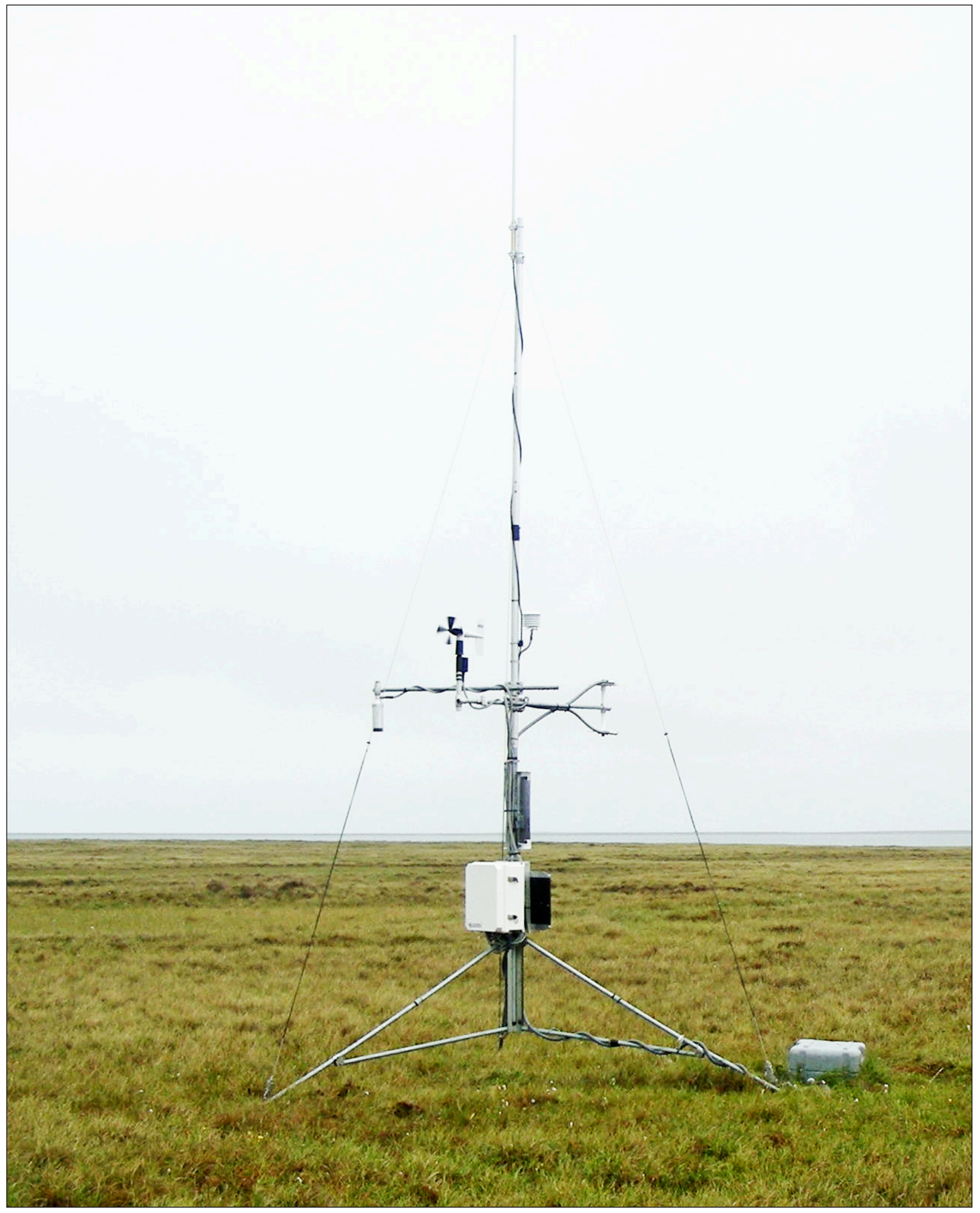

Figure L-2. East Teshekpuk station in summer 2008. 
East Teshekpuk Windroses
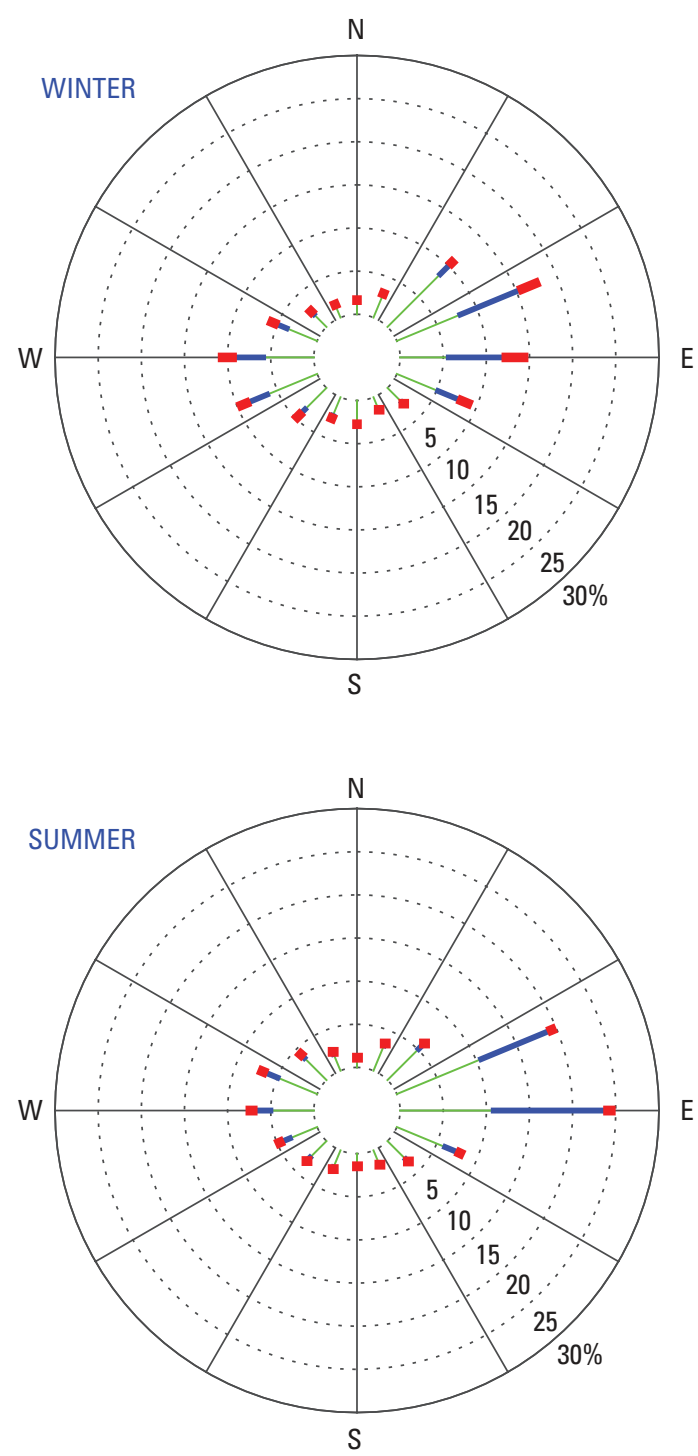

EXPLANATION

Wind speed $(\mathrm{m} / \mathrm{s})$

$0.5<\mathrm{U}<5$

$5<\mathrm{U}<10$

$U>10$

Figure L-3. East Teshekpuk seasonal windroses. The wind direction and speed data are divided into 16 wind direction categories (22.5 each) and 3 wind speed classes: less than $5 \mathrm{~m} / \mathrm{s}$, between $5 \mathrm{~m} / \mathrm{s}$ and $10 \mathrm{~m} / \mathrm{s}$, and greater than $10 \mathrm{~m} / \mathrm{s}$. The percentage of time that wind speeds occupy each class and directional category (concentric rings) is presented for each season: winter (December, January, February), spring (March, April, May), summer (June, July, August), and autumn (September, October, November). (m/s, meters per second; U, wind speed; N, north; E, east; S, south; W, west)

\section{Data Access}

List of station data ScienceBase data release files and summary tables for this report are available at https://doi.org/10.5066/F7VX0FGB. 


\section{Ikpikpuk}

GTN-P code: U39

Latitude: $70^{\circ} 26.499^{\prime} \mathrm{N}$

Longitude: $154^{\circ} 21.938^{\prime} \mathrm{W}$

Elevation: 5 meters above mean sea level

Installation date: 21 AUG 2005

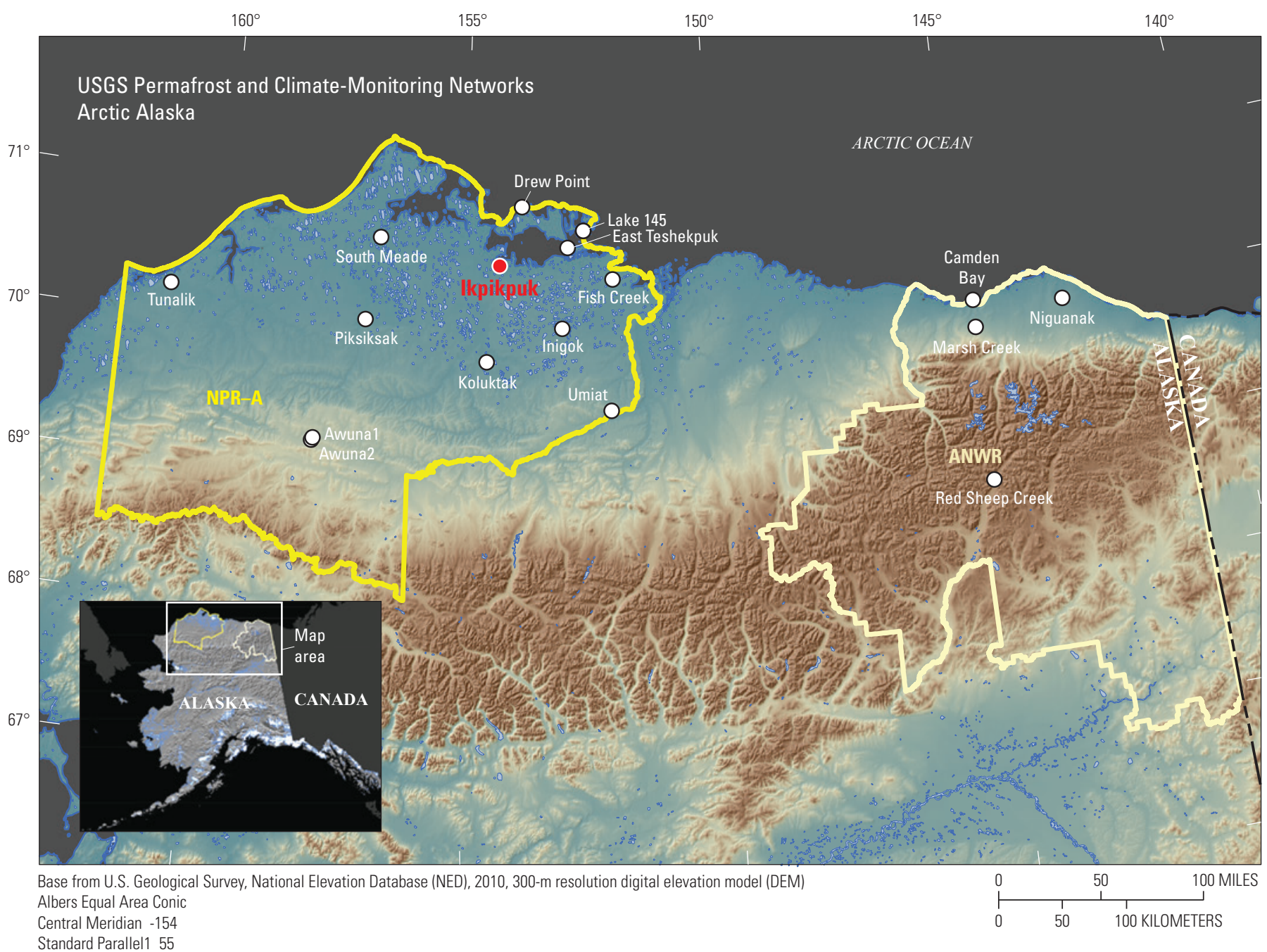

Standard Parallel1 55

Standard Parallel2 65

Figure M-1. Location map presenting the specific location of the Ikpikpuk site and its spatial relation to other sites in the monitoring network. (NPR-A, National Petroleum Reserve-Alaska; ANWR, Arctic National Wildlife Refuge) 


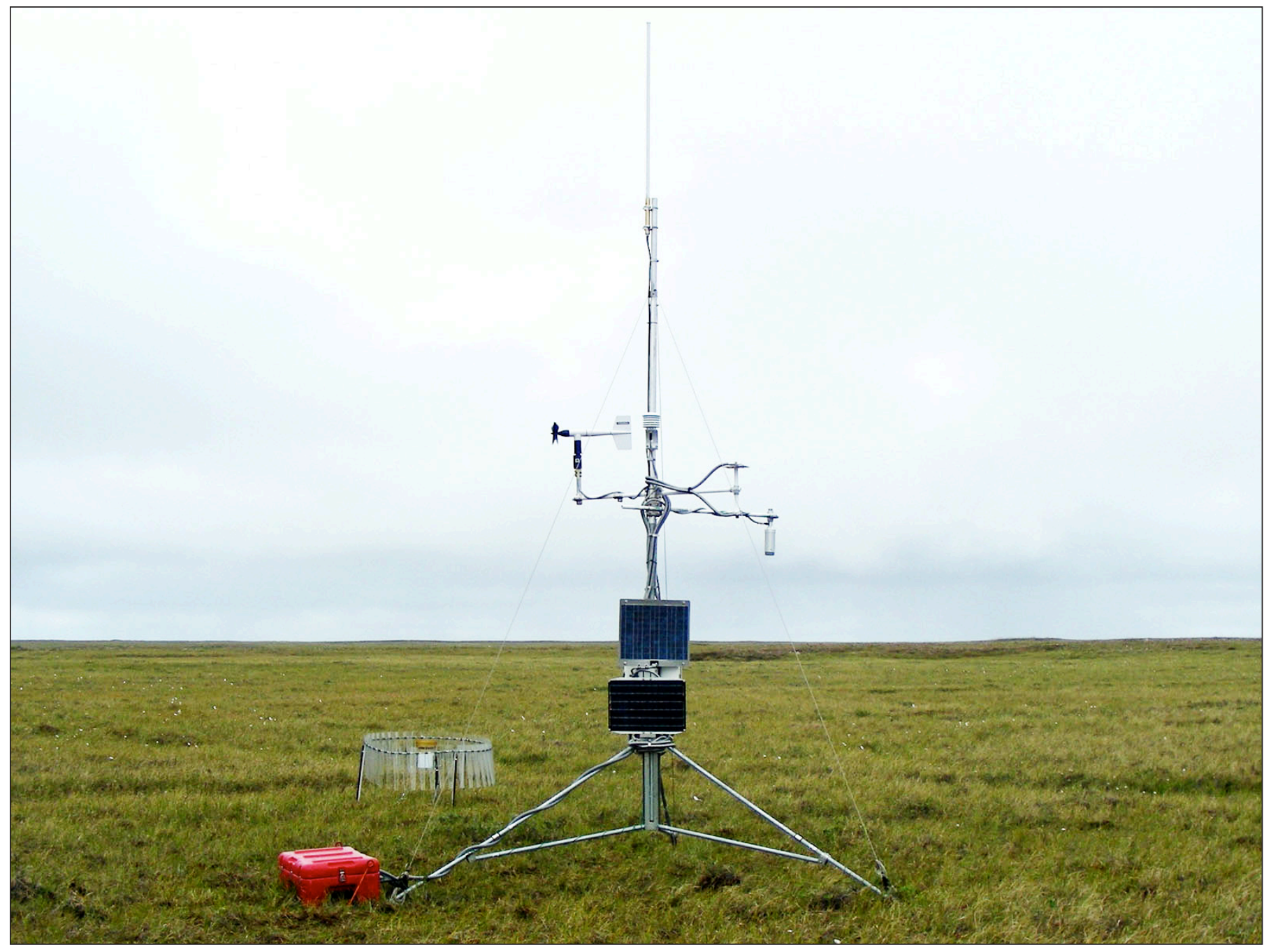

Figure M-2. Ikpikpuk station in summer 2008. 
Ikpikpuk Windroses
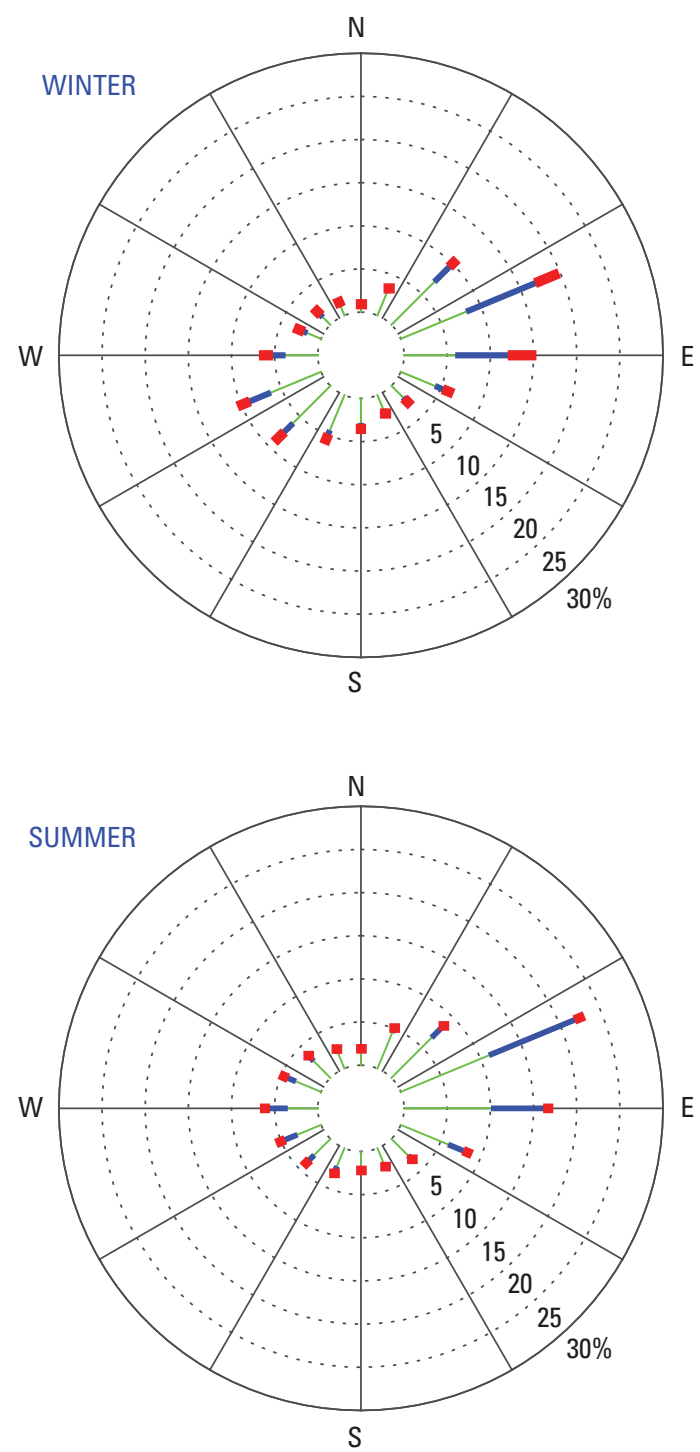

EXPLANATION

Wind speed $(\mathrm{m} / \mathrm{s})$

$0.5<\mathrm{U}<5$

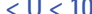

$\mathrm{U}>10$

Figure M-3. Ikpikpuk seasonal windroses. The wind direction and speed data are divided into 16 wind direction categories $\left(22.5^{\circ}\right.$ each) and 3 wind speed classes: less than $5 \mathrm{~m} / \mathrm{s}$, between $5 \mathrm{~m} / \mathrm{s}$ and $10 \mathrm{~m} / \mathrm{s}$, and greater than $10 \mathrm{~m} / \mathrm{s}$. The percentage of time that wind speeds occupy each class and directional category (concentric rings) is presented for each season: winter (December, January, February), spring (March, April, May), summer (June, July, August), and autumn (September, October, November). (m/s, meters per second; U, wind speed; N, north; E, east; S, south; W, west)

\section{Data Access}

List of station data ScienceBase data release files and summary tables for this report are available at https://doi.org/10.5066/F7VX0FGB. 


\section{N. Lake 145}

GTN-P code: -

Latitude: $70^{\circ} 41.388^{\prime} \mathrm{N}$

Longitude: $152^{\circ} 37.995^{\prime} \mathrm{W}$

Elevation: 6 meters above mean sea level

Installation date: 13 AUG 2007

$160^{\circ}$

$155^{\circ}$

$150^{\circ}$

$145^{\circ}$

$140^{\circ}$

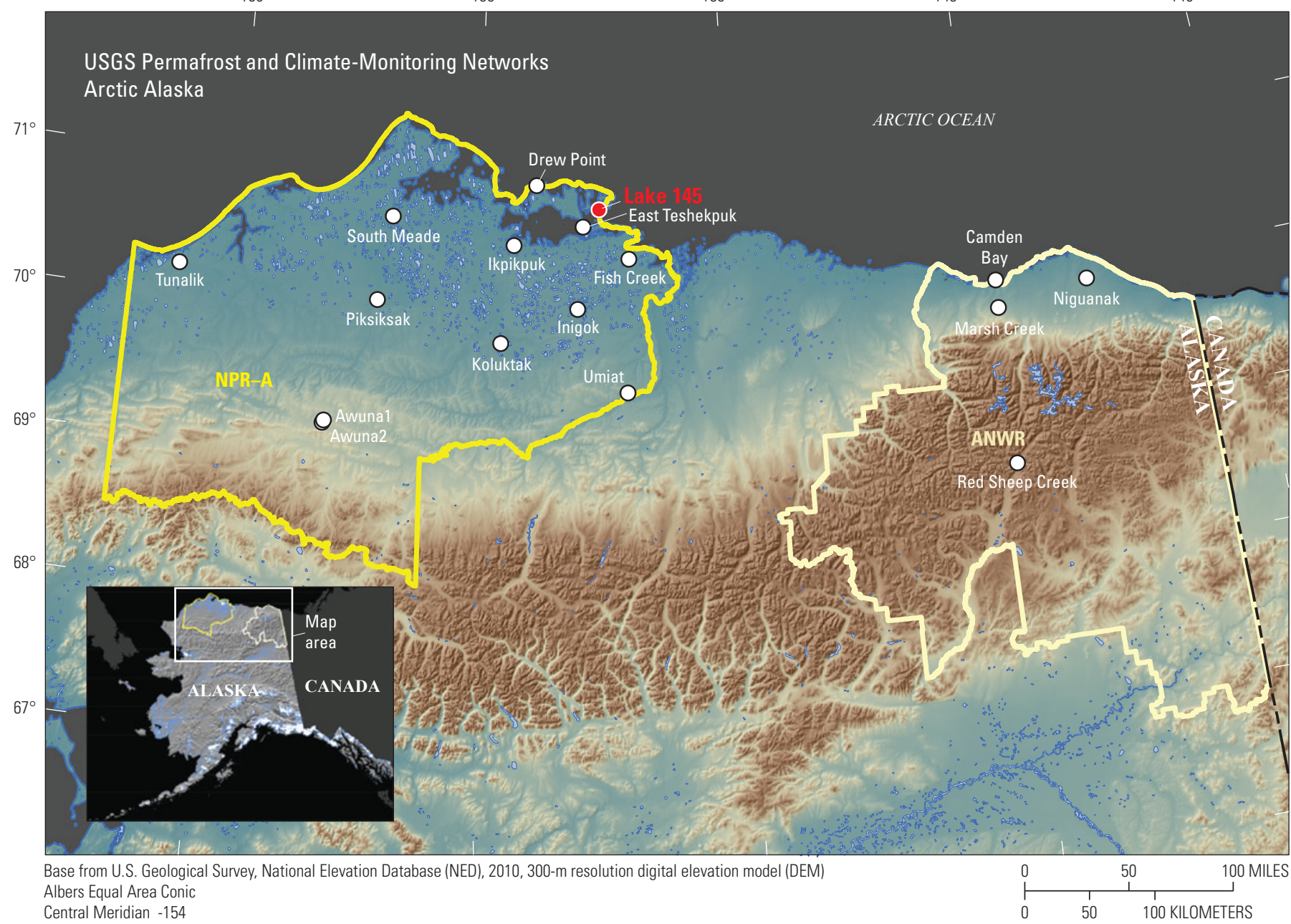

Central Meridian -154

Standard Parallel1 55

Standard Parallel2 65

Figure N-1. Location map presenting the specific location of the Lake 145 site and its spatial relation to other sites in the monitoring network. (NPR-A, National Petroleum Reserve-Alaska; ANWR, Arctic National Wildlife Refuge) 


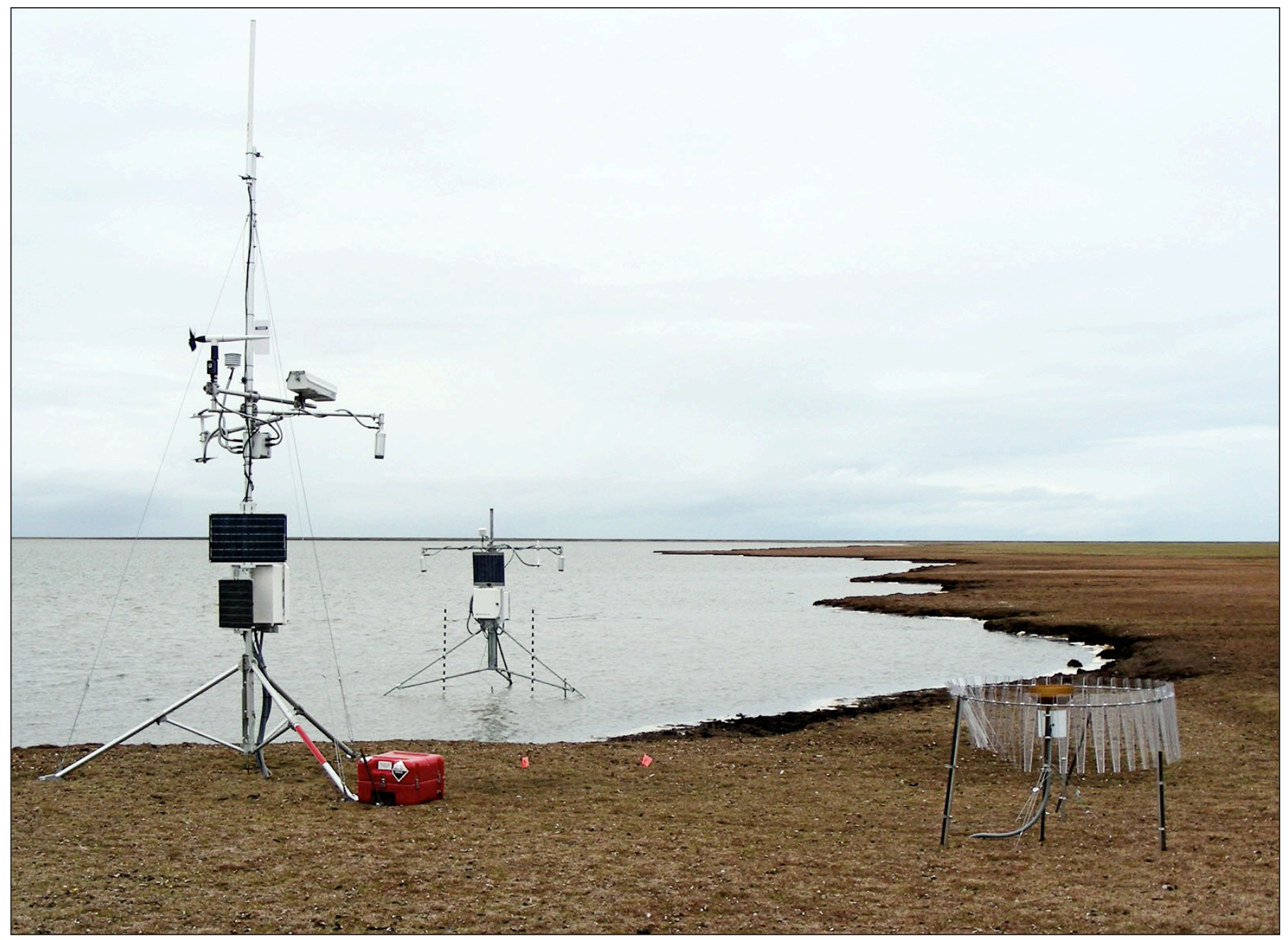

Figure N-2. Lake 145 station in summer 2008. 
Lake145Shore Windroses
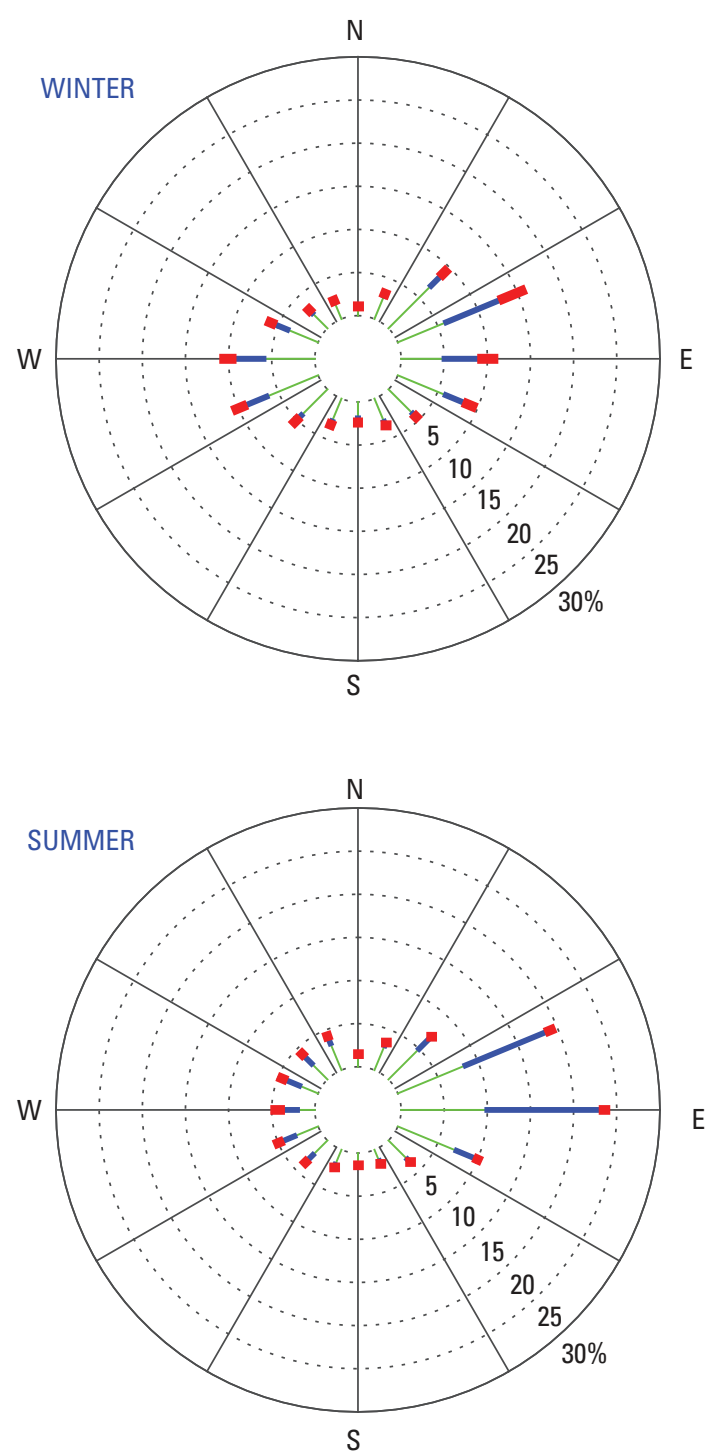
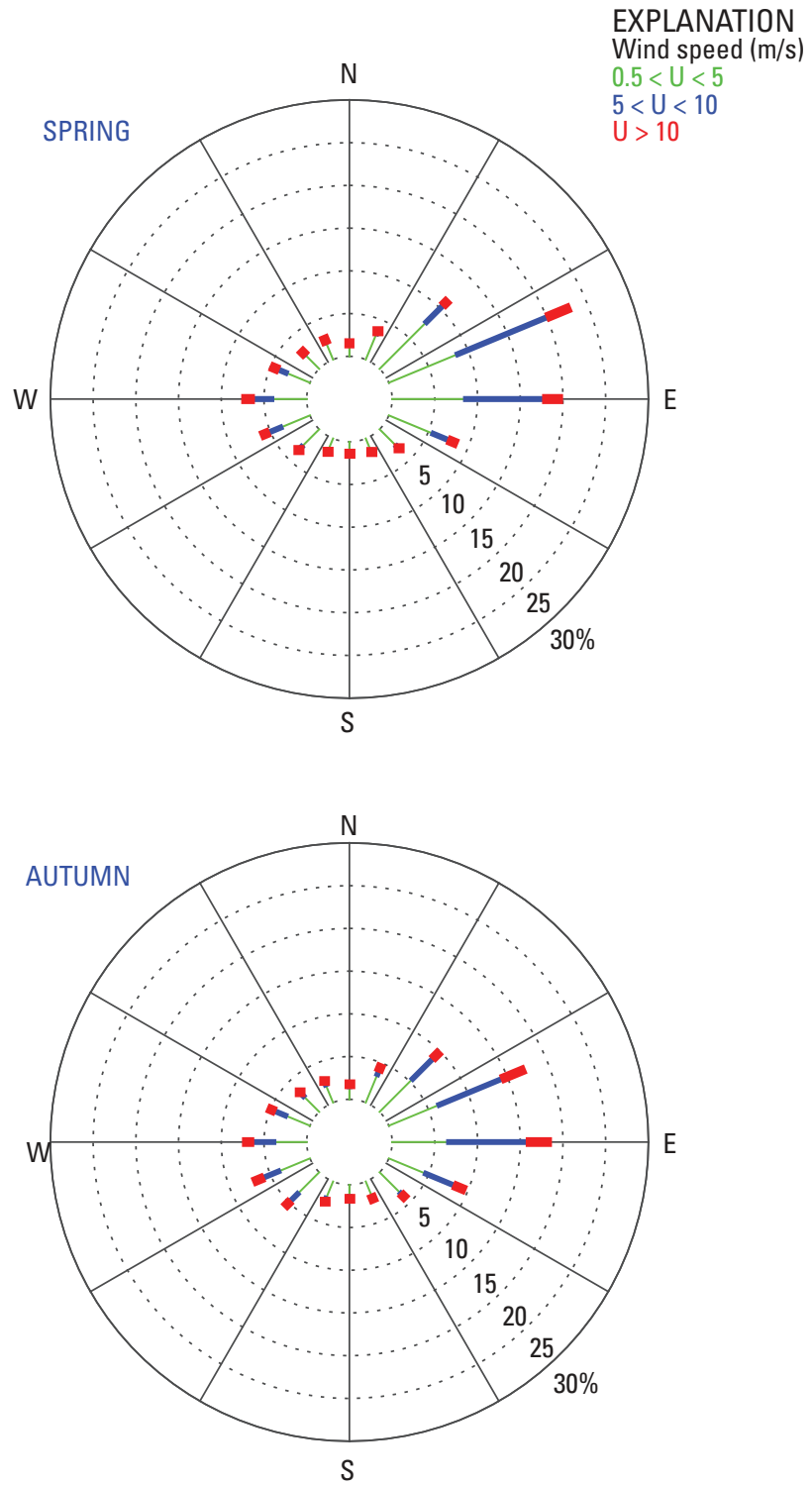

Figure N-3. Lake 145 seasonal windroses. The wind direction and speed data are divided into 16 wind direction categories $\left(22.5^{\circ}\right.$ each $)$ and 3 wind speed classes: less than $5 \mathrm{~m} / \mathrm{s}$, between $5 \mathrm{~m} / \mathrm{s}$ and $10 \mathrm{~m} / \mathrm{s}$, and greater than $10 \mathrm{~m} / \mathrm{s}$. The percentage of time that wind speeds occupy each class and directional category (concentric rings) is presented for each season: winter (December, January, February), spring (March, April, May), summer (June, July, August), and autumn (September, October, November). (m/s, meters per second; U, wind speed; N, north; E, east; $S$, south; W, west)

\section{Data Access}

List of station data ScienceBase data release files and summary tables for this report are available at https://doi.org/10.5066/F7VX0FGB. 


\section{Niguanak}

GTN-P code: U29

Latitude: $69^{\circ} 53.363^{\prime} \mathrm{N}$

Longitude: $142^{\circ} 59.037^{\prime} \mathrm{W}$

Elevation: 84 meters above mean sea level

Installation date: 18 AUG 2000

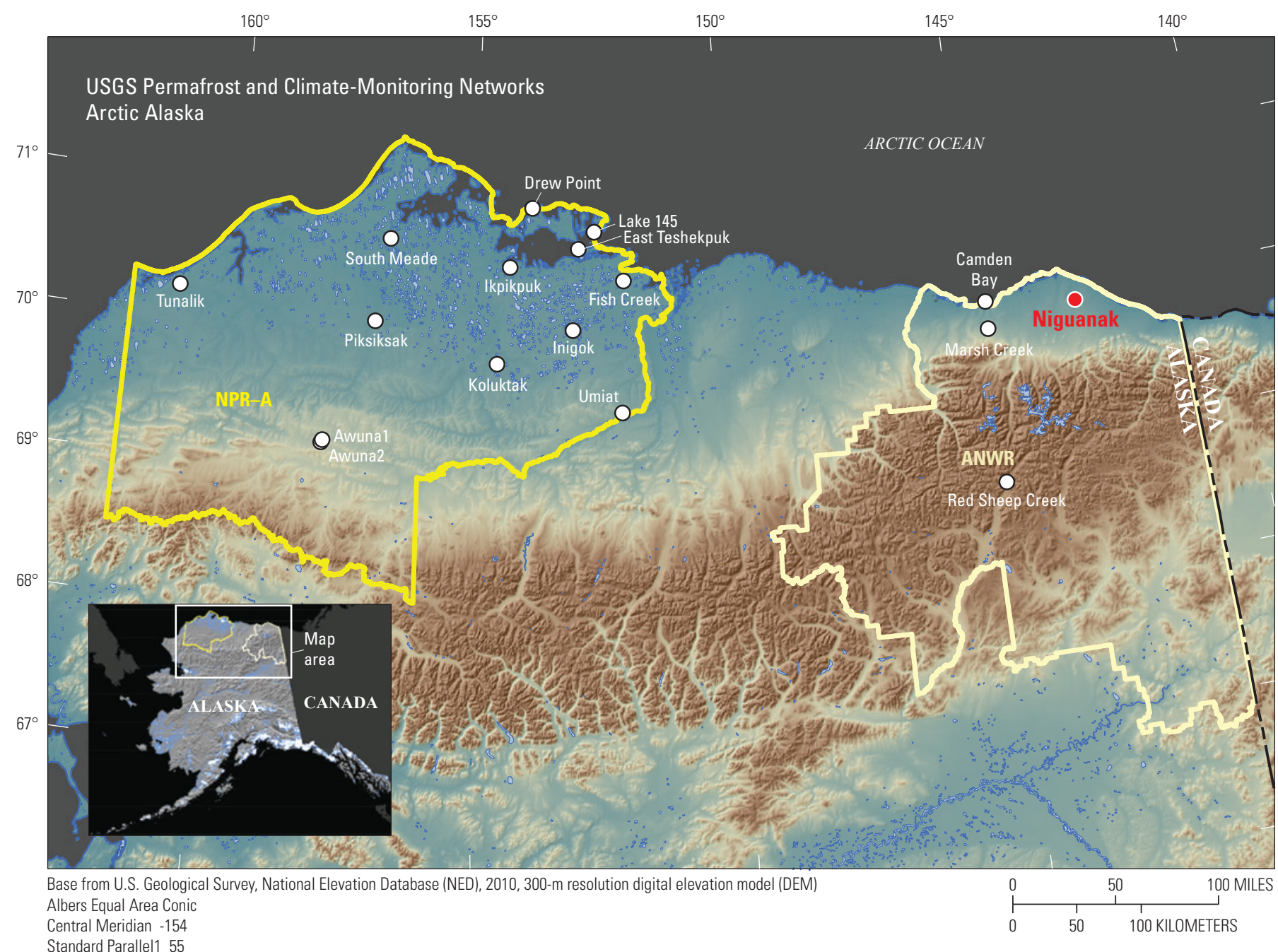

Standard Parallel1 55

Standard Parallel2 65

Figure 0-1. Location map presenting the specific location of the Niguanak site and its spatial relation to other sites in the monitoring network. (NPR-A, National Petroleum Reserve-Alaska; ANWR, Arctic National Wildlife Refuge) 


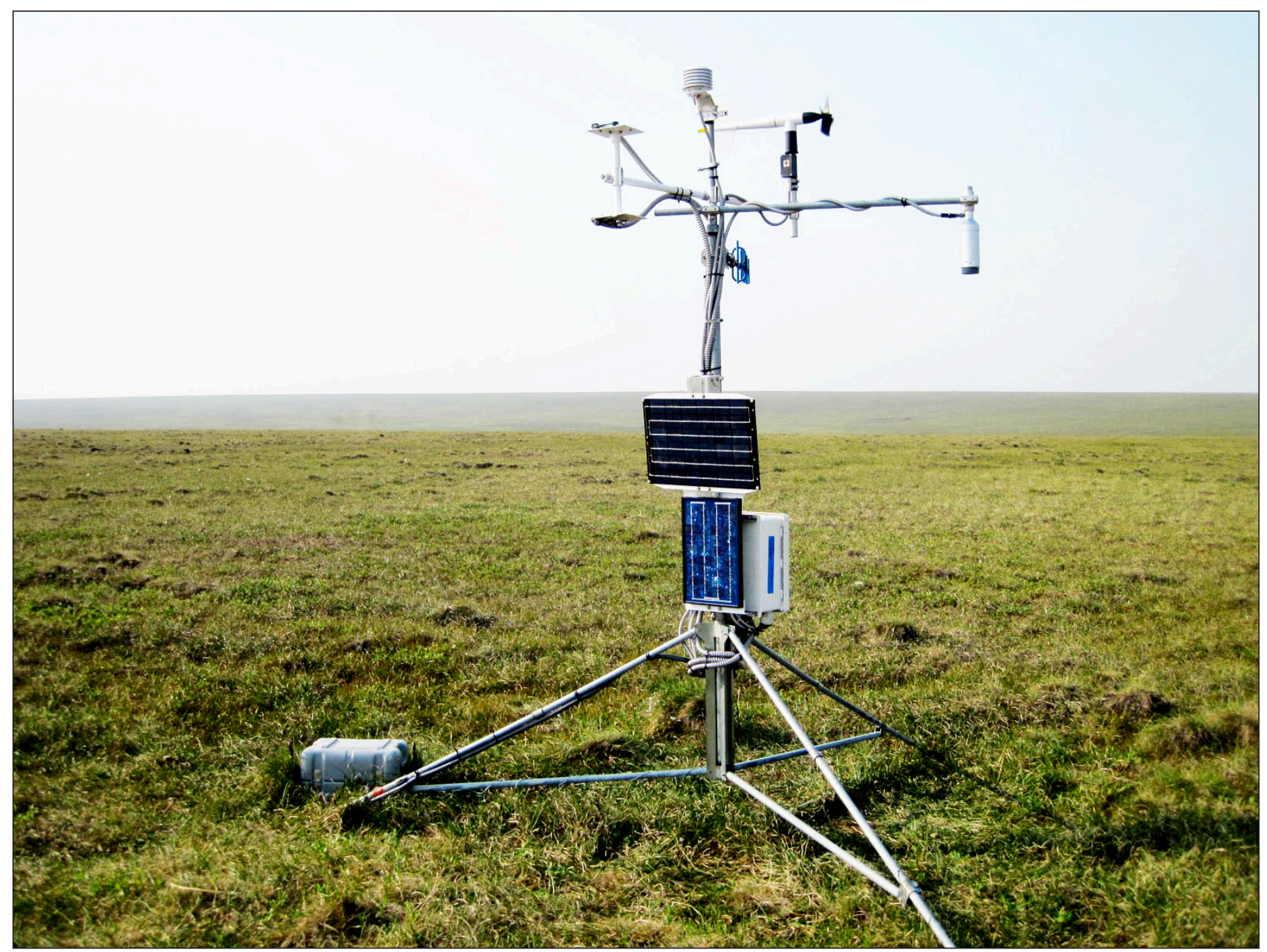

Figure 0-2. Niguanak station in summer 2008. 
Niguanak Windroses
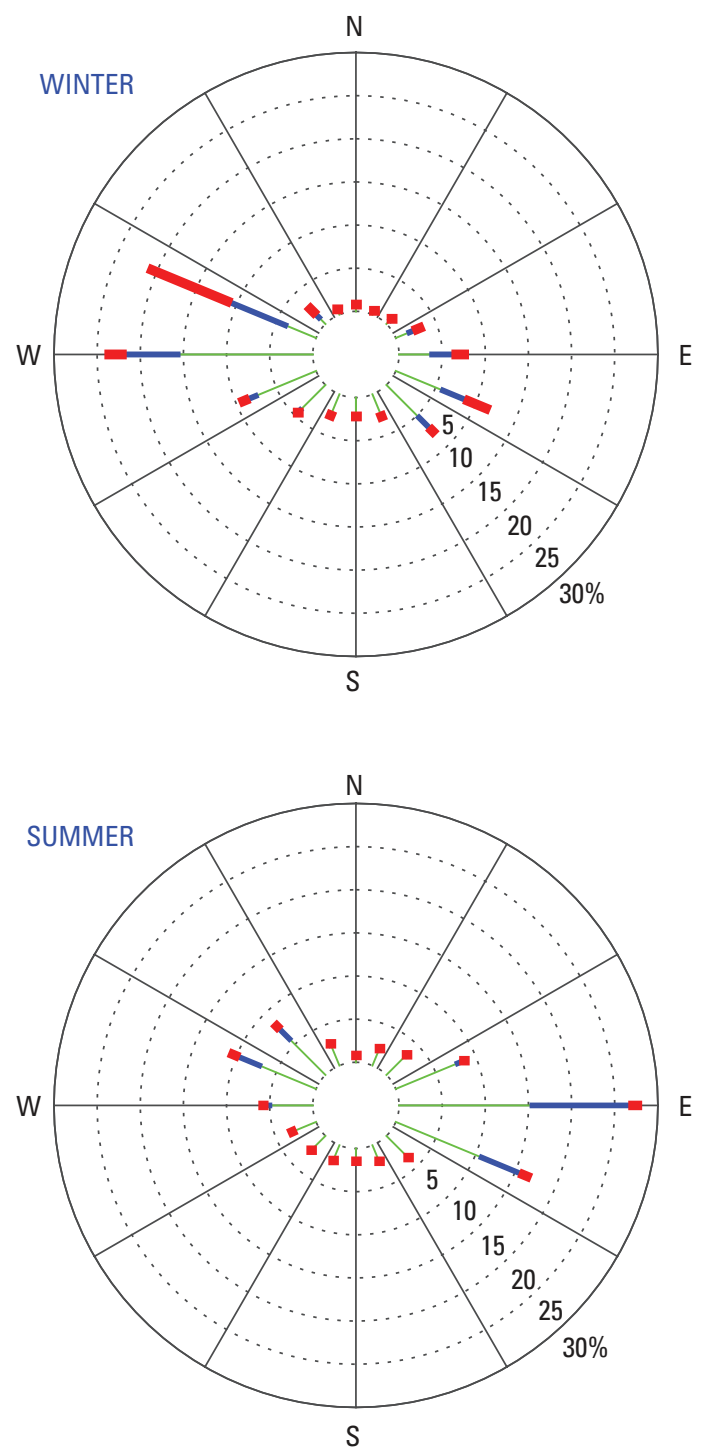
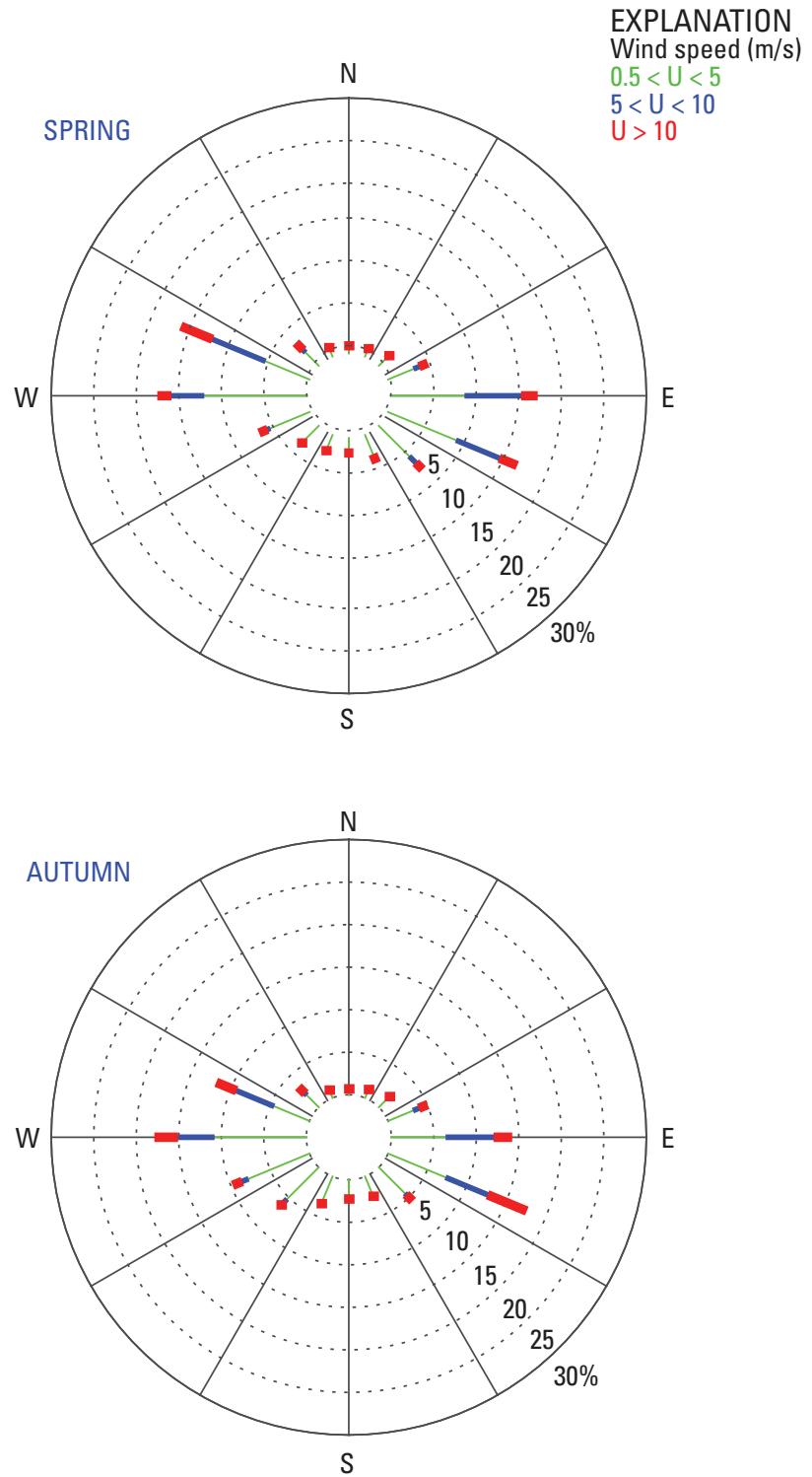

Figure 0-3. Niguanak seasonal windroses. The wind direction and speed data are divided into 16 wind direction categories $\left(22.5^{\circ}\right.$ each) and 3 wind speed classes: less than $5 \mathrm{~m} / \mathrm{s}$, between $5 \mathrm{~m} / \mathrm{s}$ and $10 \mathrm{~m} / \mathrm{s}$, and greater than $10 \mathrm{~m} / \mathrm{s}$. The percentage of time that wind speeds occupy each class and directional category (concentric rings) is presented for each season: winter (December, January, February), spring (March, April, May), summer (June, July, August), and autumn (September, October, November). (m/s, meters per second; $U$, wind speed; $N$, north; $E$, east; $S$, south; $W$, west)

\section{Data Access}

List of station data ScienceBase data release files and summary tables for this report are available at https://doi.org/10.5066/F7VX0FGB. 


\section{P. Marsh Creek}

GTN-P code: U31

Latitude: $69^{\circ} 46.657^{\prime} \mathrm{N}$

Longitude: $144^{\circ} 47.595^{\prime} \mathrm{W}$

Elevation: 260 meters above mean sea level

Installation date: 03 AUG 2001

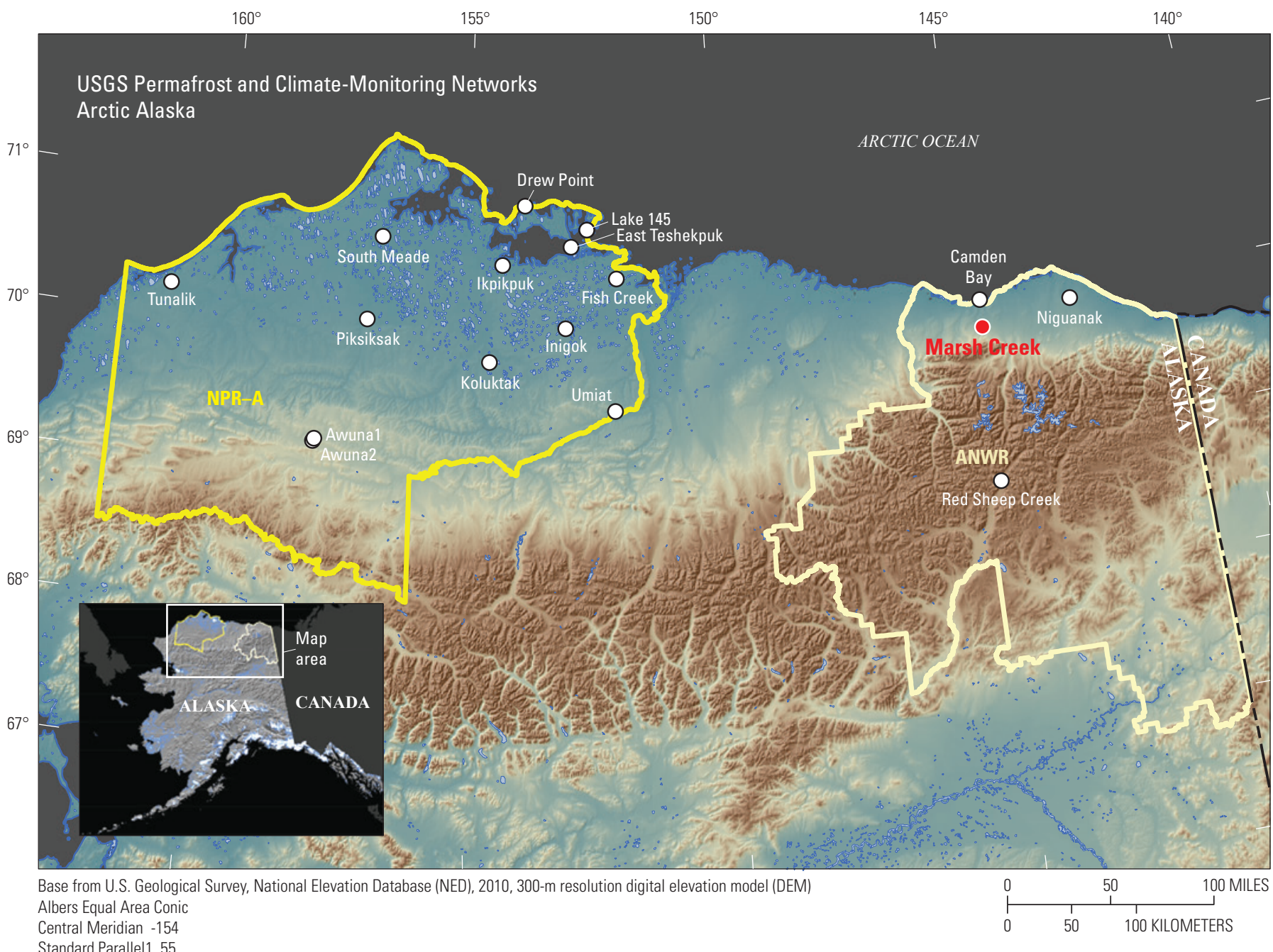

Central Meridian -15

Standard Parallel1 55

Figure P-1. Location map presenting the specific location of the Marsh Creek site and its spatial relation to other sites in the monitoring network. (NPR-A, National Petroleum Reserve-Alaska; ANWR, Arctic National Wildlife Refuge) 


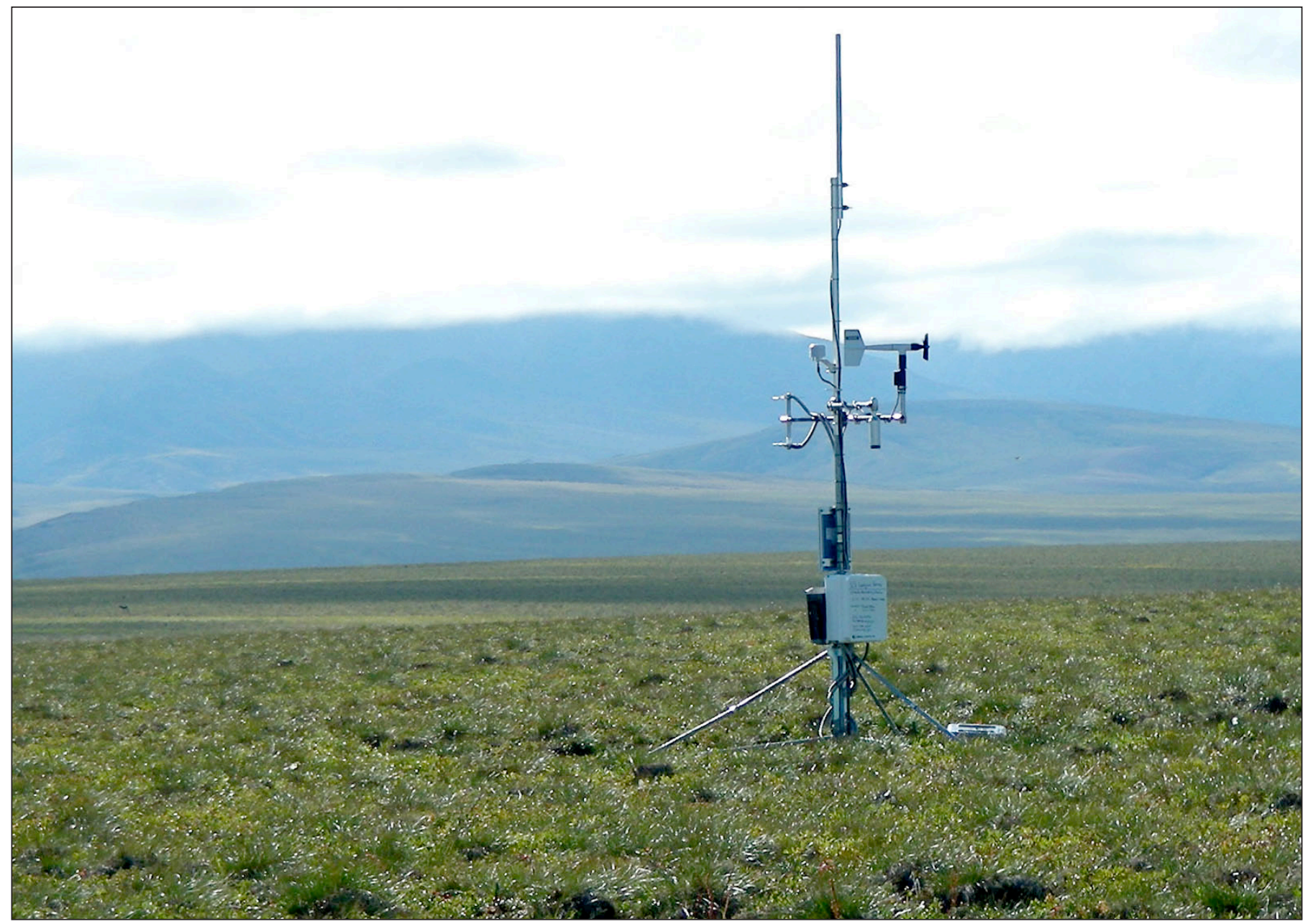

Figure P-2. Marsh Creek station in summer 2008. 
Marsh Creek Windroses
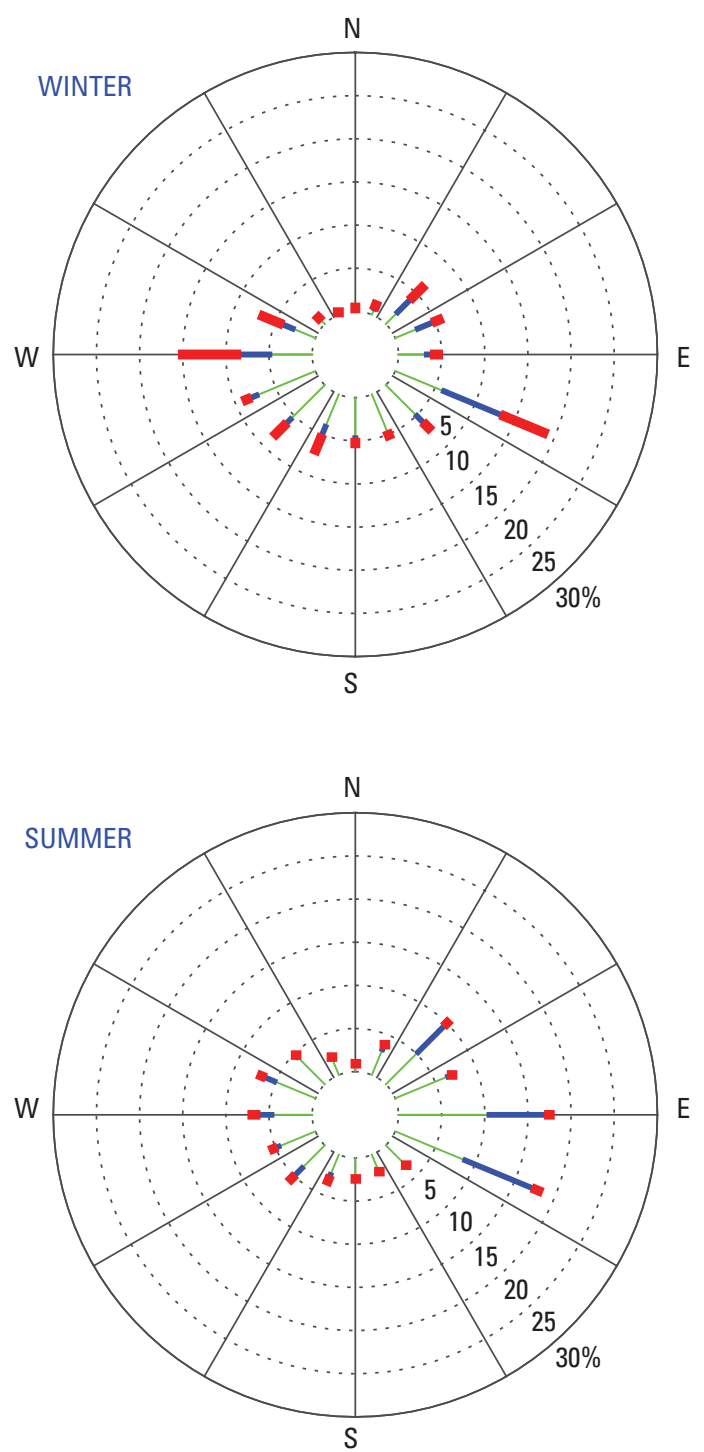
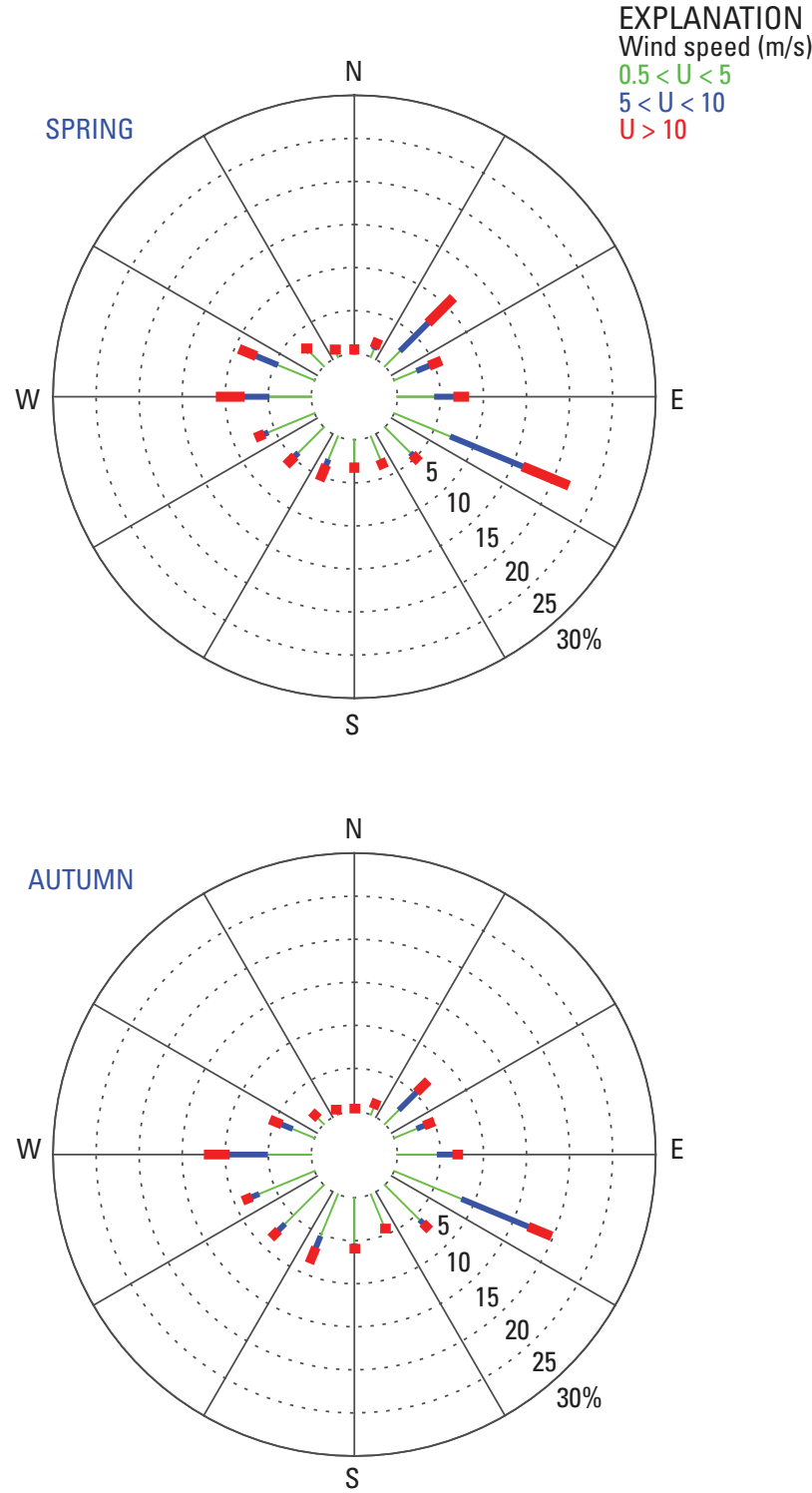

Figure P-3. Marsh Creek seasonal windroses. The wind direction and speed data are divided into 16 wind direction categories $\left(22.5^{\circ}\right.$ each) and 3 wind speed classes: less than $5 \mathrm{~m} / \mathrm{s}$, between $5 \mathrm{~m} / \mathrm{s}$ and $10 \mathrm{~m} / \mathrm{s}$, and greater than $10 \mathrm{~m} / \mathrm{s}$. The percentage of time that wind speeds occupy each class and directional category (concentric rings) is presented for each season: winter (December, January, February), spring (March, April, May), summer (June, July, August), and autumn (September, October, November). (m/s, meters per second; U, wind speed; N, north; E, east; S, south; W, west)

\section{Data Access}

List of station data ScienceBase data release files and summary tables for this report are available at https://doi.org/10.5066/F7VX0FGB. 


\section{Camden Bay}

GTN-P code: U34

Latitude: $69^{\circ} 58.317^{\prime} \mathrm{N}$

Longitude: $144^{\circ} 46.234^{\prime} \mathrm{W}$

Elevation: 4 meters above mean sea level

Installation date: 14 AUG 2003

$160^{\circ}$

$155^{\circ}$

$150^{\circ}$

$145^{\circ}$

$140^{\circ}$

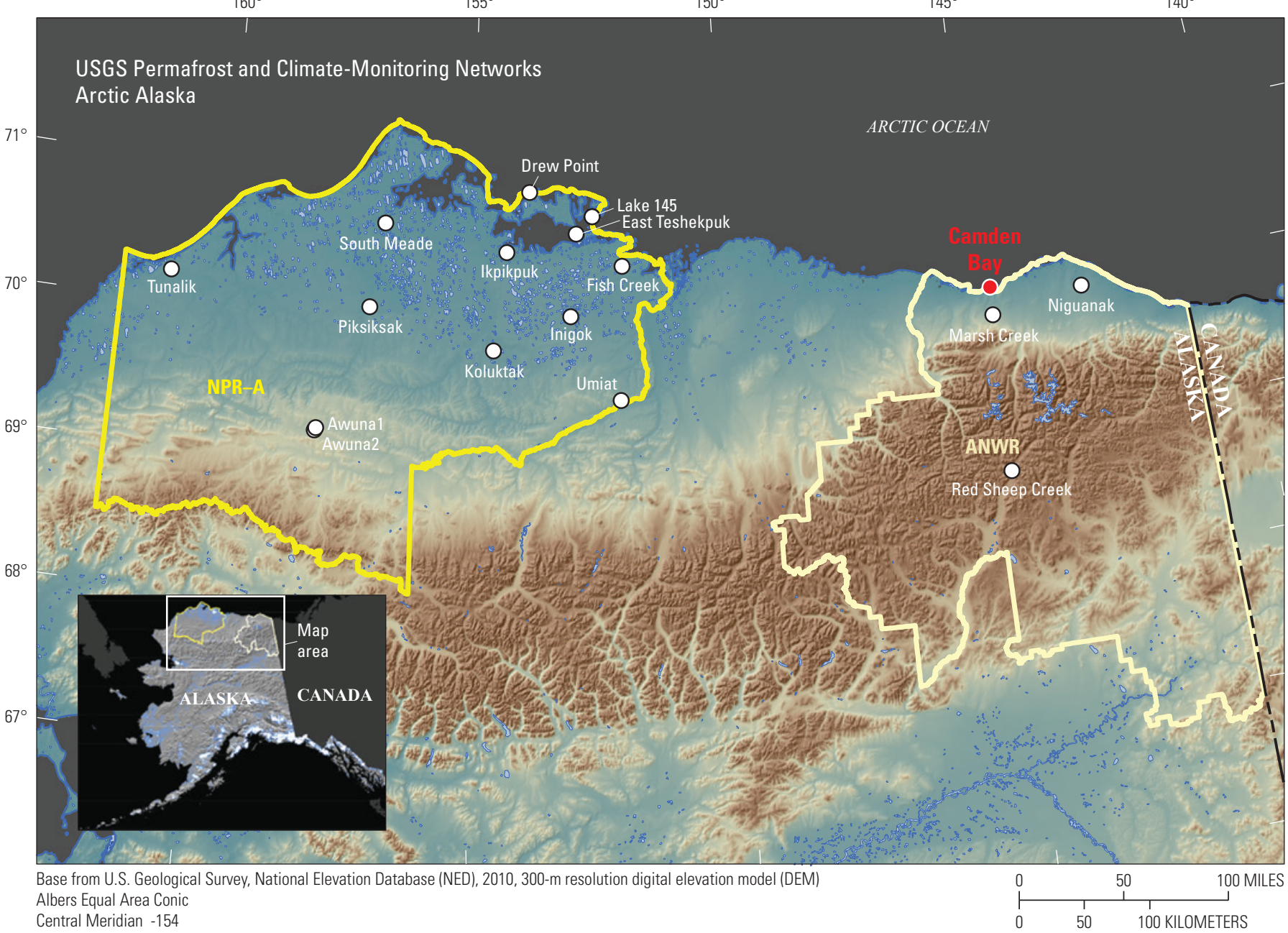

Standard Parallel1 55

Standard Parallel2 65

Figure 0-1. Location map presenting the specific location of the Camden Bay site and its spatial relation to other sites in the monitoring network. (NPR-A, National Petroleum Reserve-Alaska; ANWR, Arctic National Wildlife Refuge) 


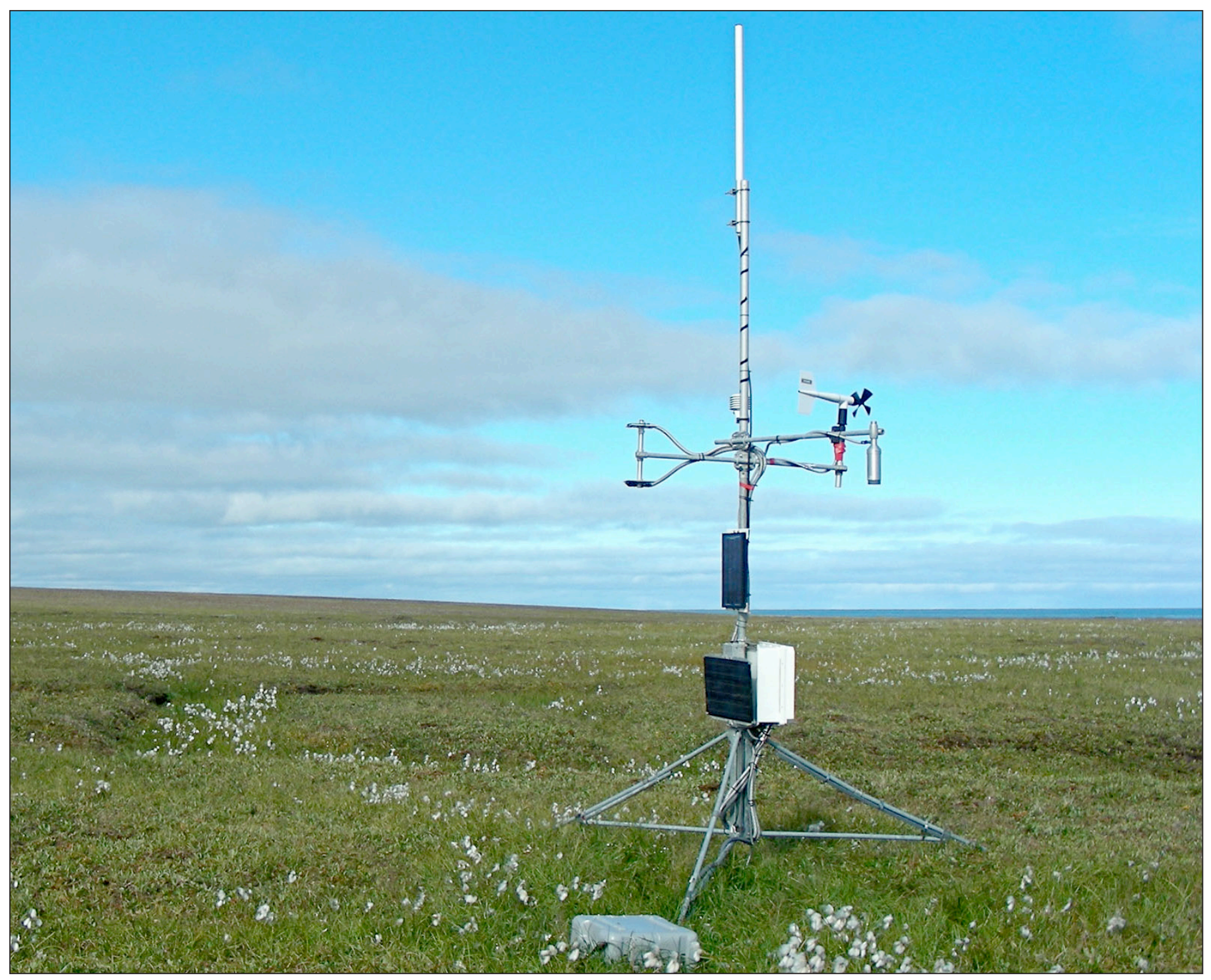

Figure 0-2. Camden Bay station in summer 2008. 


\section{Camden Bay Windroses}
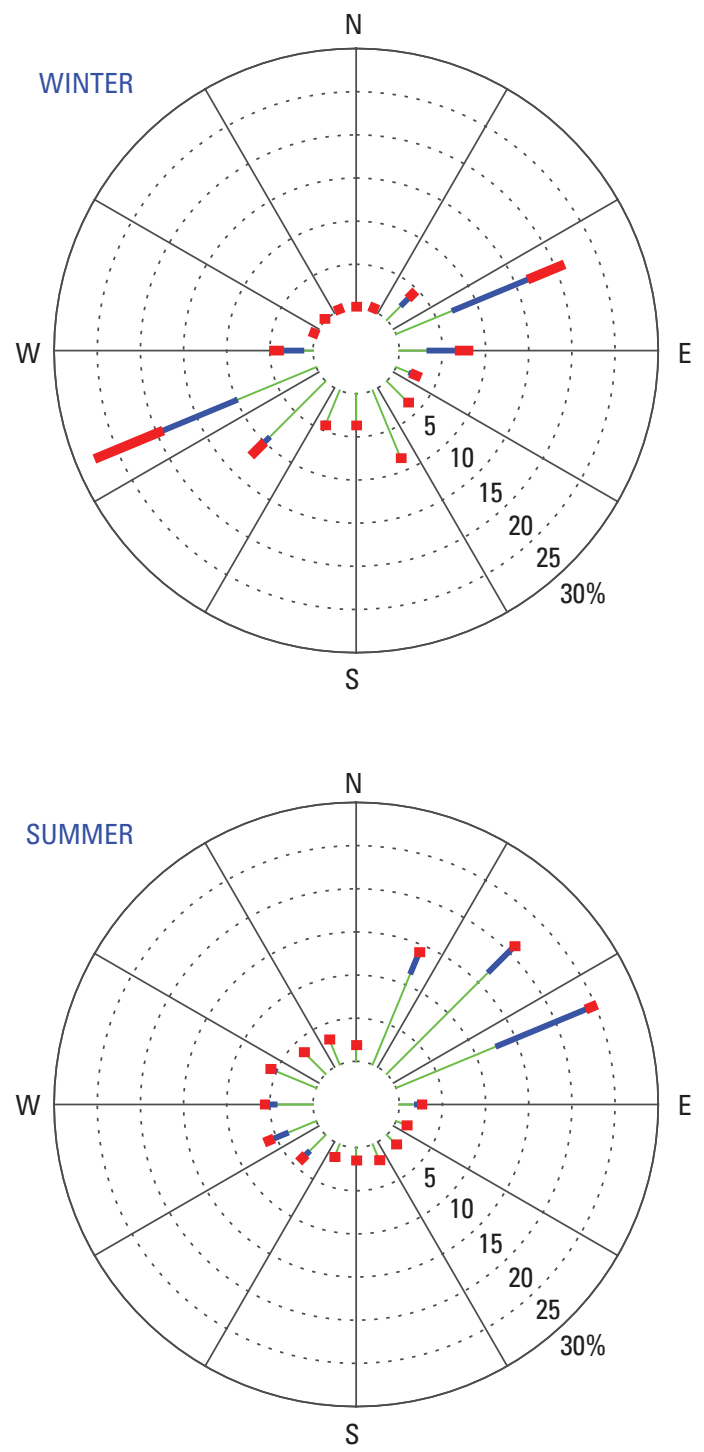

EXPLANATION

Wind speed $(\mathrm{m} / \mathrm{s})$

$0.5<\mathrm{U}<5$

$5<\mathrm{U}<10$

$\mathrm{U}>10$

Figure 0-3. Camden Bay seasonal windroses. The wind direction and speed data are divided into 16 wind direction categories $\left(22.5^{\circ}\right.$ each) and 3 wind speed classes: less than $5 \mathrm{~m} / \mathrm{s}$, between $5 \mathrm{~m} / \mathrm{s}$ and $10 \mathrm{~m} / \mathrm{s}$, and greater than $10 \mathrm{~m} / \mathrm{s}$. The percentage of time that wind speeds occupy each class and directional category (concentric rings) is presented for each season: winter (December, January, February), spring (March, April, May), summer (June, July, August), and autumn (September, October, November). (m/s, meters per second; U, wind speed; N, north; E, east; S, south; W, west)

Data Access

List of station data ScienceBase data release files and summary tables for this report are available at https://doi.org/10.5066/F7VX0FGB. 


\section{R. Red Sheep Creek}

GTN-P code: U36

Latitude: $68^{\circ} 40.898^{\prime} \mathrm{N}$

Longitude: $144^{\circ} 50.524^{\prime} \mathrm{W}$

Elevation: 785 meters above mean sea level

Installation date: 03 AUG 2004

$160^{\circ}$

$155^{\circ}$

$150^{\circ}$

$145^{\circ}$

$140^{\circ}$

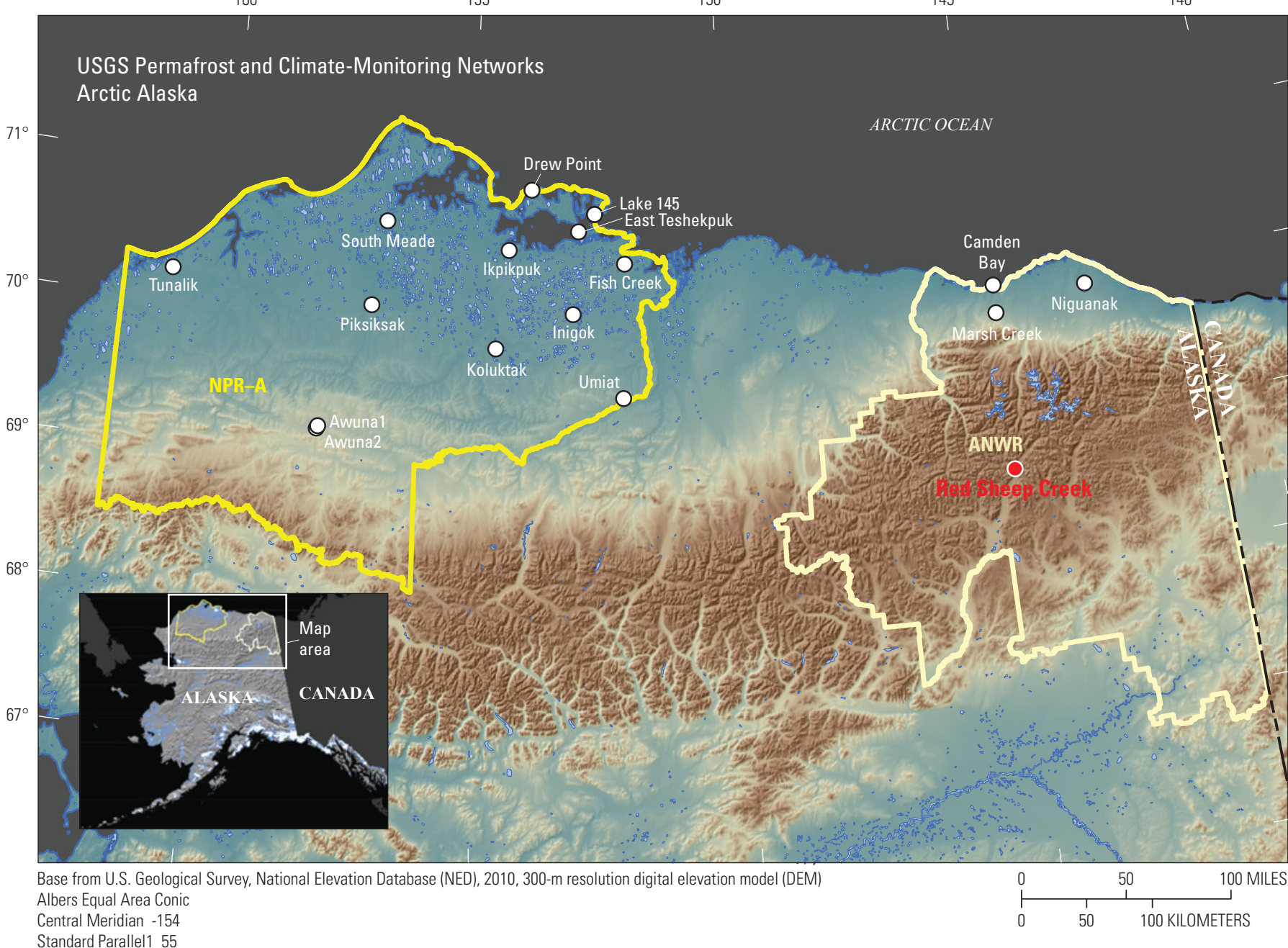

Standa

Standard Parallel2 65

Figure R-1. Location map presenting the specific location of the Red Sheep Creek site and its spatial relation to other sites in the monitoring network. (NPR-A, National Petroleum Reserve-Alaska; ANWR, Arctic National Wildlife Refuge) 


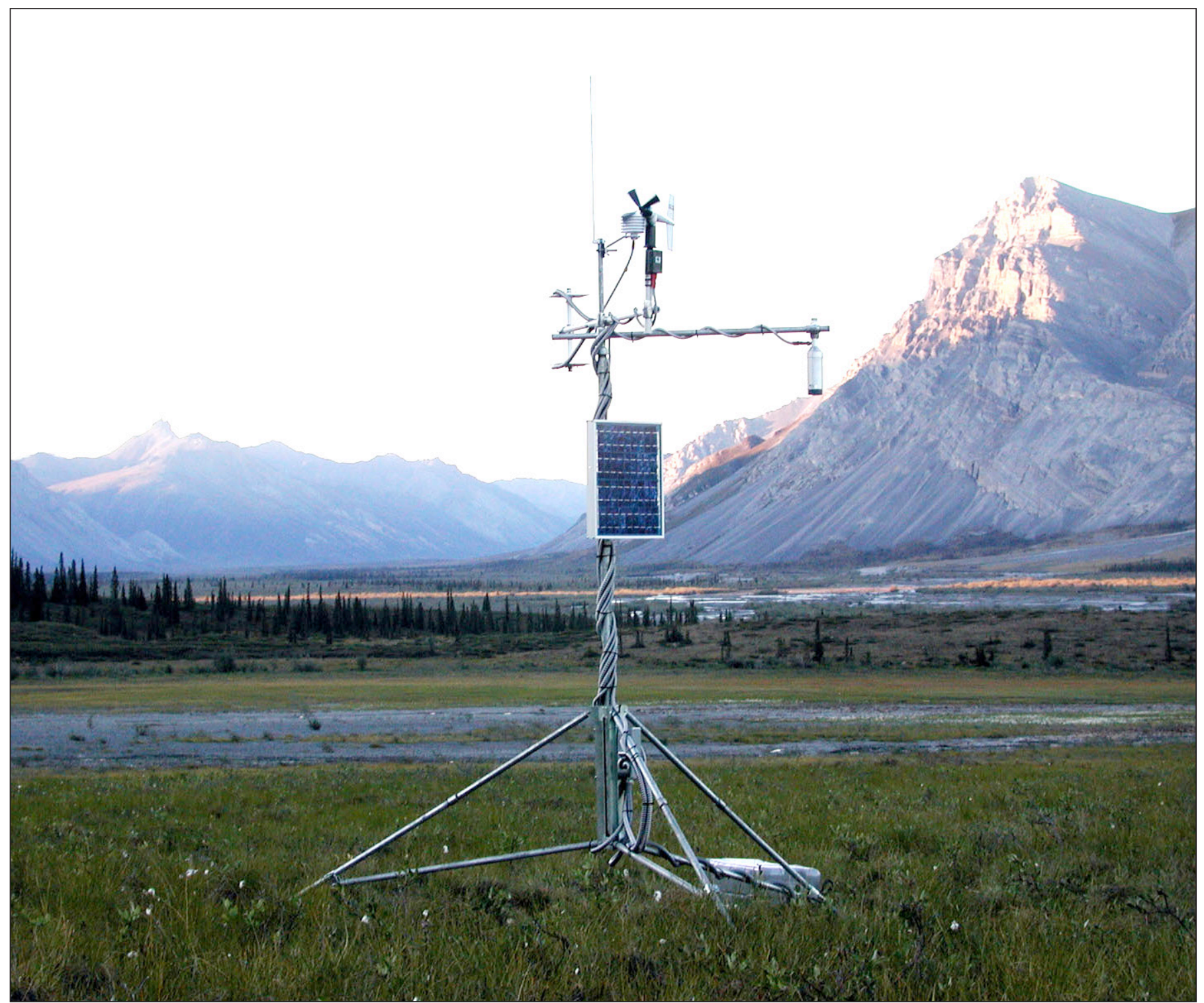

Figure R-2. Red Sheep Creek station in summer 2008. 
Red Sheep Creek Windroses
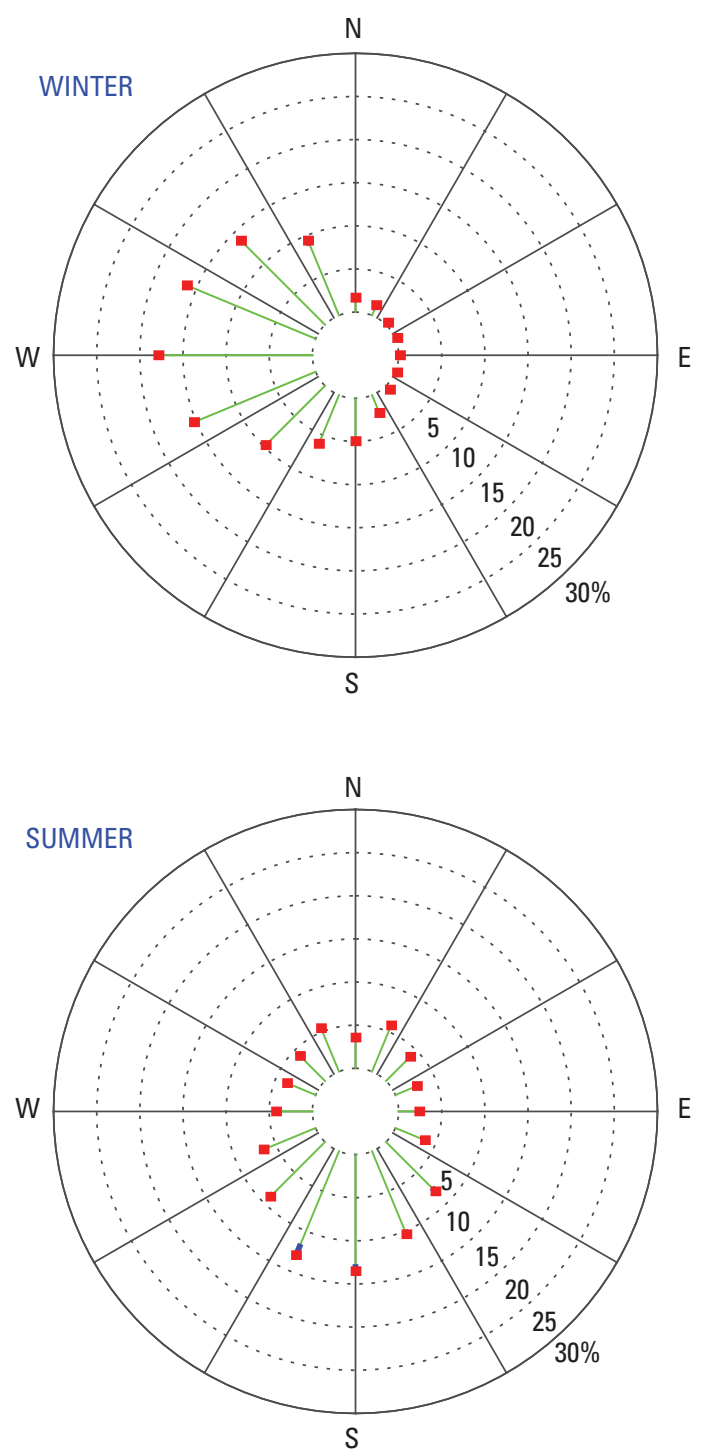
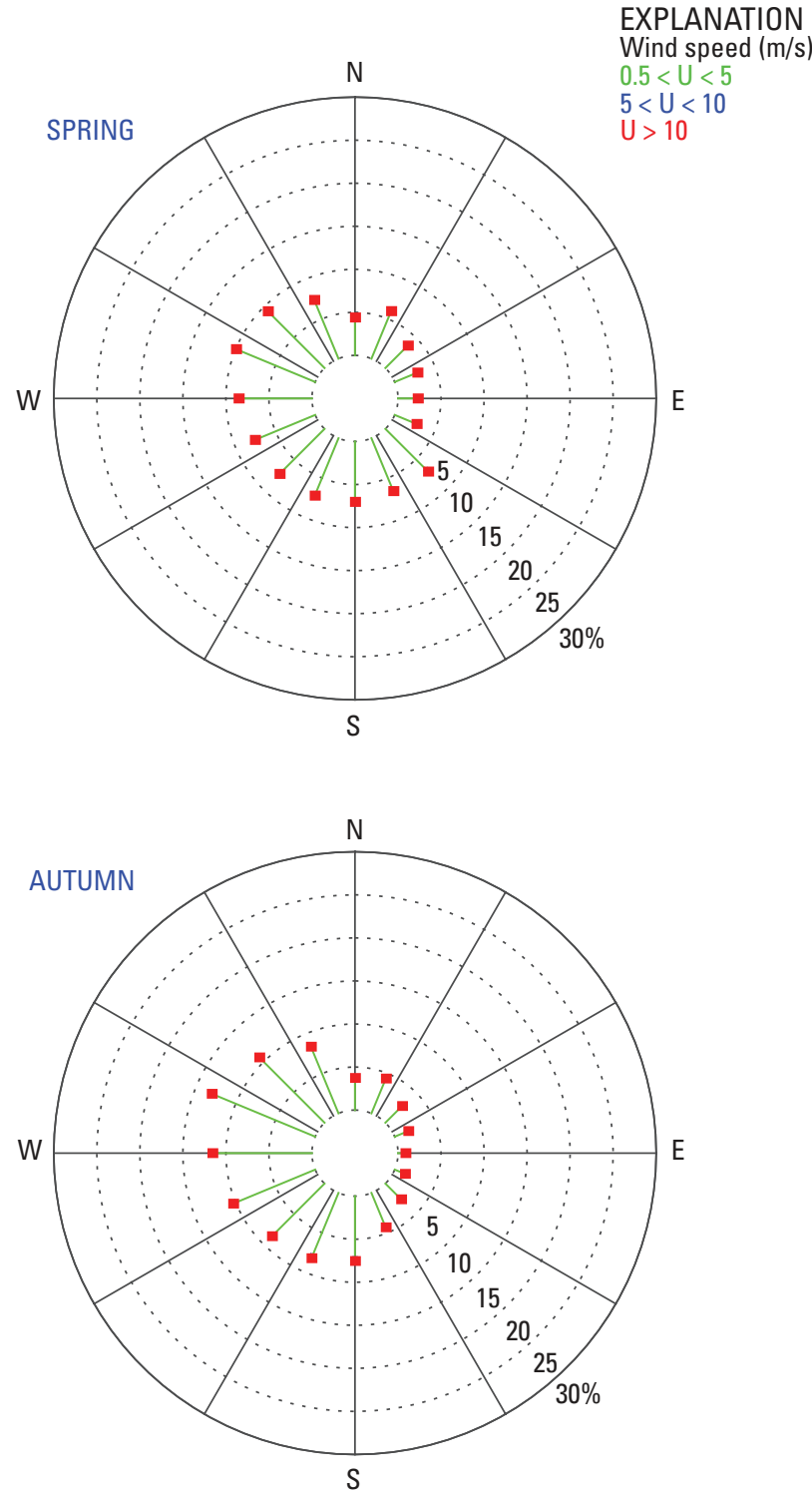

Figure R-3. Red Sheep Creek seasonal windroses. The wind direction and speed data are divided into 16 wind direction categories $\left(22.5^{\circ}\right.$ each) and 3 wind speed classes: less than $5 \mathrm{~m} / \mathrm{s}$, between $5 \mathrm{~m} / \mathrm{s}$ and $10 \mathrm{~m} / \mathrm{s}$, and greater than $10 \mathrm{~m} / \mathrm{s}$. The percentage of time that wind speeds occupy each class and directional category (concentric rings) is presented for each season: winter (December, January, February), spring (March, April, May), summer (June, July, August), and autumn (September, October, November). (m/s, meters per second; U, wind speed; N, north; E, east; S, south; W, west)

\section{Data Access}

List of station data ScienceBase data release files and summary tables for this report are available at https://doi.org/10.5066/F7VX0FGB. 


\section{References Cited}

Arctic Council, 2005, Arctic climate impact assessmentScientific report: Cambridge and New York, Cambridge University Press, 1,046 p.

Chapman, W.L., and Walsh, J.E., 2007, Simulations of Arctic temperature and pressure by global coupled models: Journal of Climate, v. 20, p. 609-632.

Clow, G.D., DeGange, A.R., Derksen, D.V., and Zimmerman, C.E., 2011, Climate change considerations, chap. 4 of Holland-Bartels, Leslie, and Pierce, Brenda, eds., An evaluation of the science needs to inform decisions on Outer Continental Shelf energy development in the Chukchi and Beaufort Seas, Alaska: U.S. Geological Survey Circular 1370, p. 81-108.

DeGange, A.R., Oakley, K.L., Irvine, G.V., Mayfield, G., Frenzel, S.A., Trawicki, J., Lassuy, D., Woodson, D., Talbot, S.L., and Wenburg, J.K., 2005, Future challenges projectReport on the regional workshop for Alaska, Washington, Idaho, and Oregon, June 1-2, 2005, Anchorage, Alaska: U.S. Fish and Wildlife Service and U.S. Geological Survey, $62 \mathrm{p}$.

Houghton, J.T., Ding, Y., Griggs, D.J., Noguer, Maria, van der Linden, P.J., Dai, X., Maskell, K., and Johnson, C.A., eds., 2001, Climate Change 2001-The scientific basisContribution of Working Group I to the Third Assessment Report of the Intergovernmental Panel on Climate Change: Cambridge, Cambridge University Press, United Kingdom and New York, NY, USA, 881 p.

Jeffries, M.O., Richter-Menge, J.A., and Overland, J.E., eds., 2012, Arctic report card 2012: National Oceanic and Atmospheric Administration, Arctic Research Program, accessed September 1, 2012, at http://www.arctic.noaa.gov/reportcard.

Lawrence, D.M., Slater, A.G., Tomas, R.A., Holland, M.M., and Deser, Clara, 2008, Accelerated Arctic land warming and permafrost degradation during rapid sea ice loss: Geophysical Research Letters, v. 35, L11506, http://dx.doi.org/10.1029/2008GL033985.

National Research Council, 2001, Climate change scienceAn analysis of some key questions: National Academies Press, National Research Council-Committee on the Science of Climate Change, $42 \mathrm{p}$.

National Research Council, 2010, Advancing the science of climate change: National Academies Press, National Research Council-Panel on Advancing the Science of Climate Change, $528 \mathrm{p}$.

Steinhart, J.S., and Hart, S.R., 1968, Calibration curves for thermistors: Deep-Sea Research, v. 15, p. 497-503.
Urban, F.E., and Clow, G.D., 2014a, DOI/GTN-P climate and active-layer data acquired in the National Petroleum Reserve-Alaska and the Arctic National Wildlife Refuge, 1998-2011: U.S. Geological Survey Data Series 812, accessed August 1, 2015, at http://dx.doi.org/10.3133/ds812.

Urban, F.E., and Clow, G.D., 2014b, DOI/GTN-P climate and active-layer data acquired in the National Petroleum Reserve-Alaska and the Arctic National Wildlife Refuge, 1998-2013: U.S. Geological Survey Data Series 892, accessed August 1, 2015, at http://dx.doi.org/10.3133/ds892.

Urban, F.E., and Clow, G.D., 2016, DOI/GTN-P climate and active-layer data acquired in the National Petroleum Reserve-Alaska and the Arctic National Wildlife Refuge, 1998-2014: U.S. Geological Survey Data Series 977, accessed July 1, 2016, at http://dx.doi.org/10.3133/ds977.

U.S. Arctic Research Commission, 2003, Climate change, permafrost, and impacts on civil infrastructure: U.S. Arctic Research Commission Permafrost Task Force, Special Report 01-03, $63 \mathrm{p}$.

Walsh, J.E., 2008, Climate of the arctic marine environment: Ecological Applications, v. 18, no. 2 Supplement, p. S3-S22.

Publishing support provided by the Science Publishing Network, Denver Publishing Service Center

For more information concerning the research in this report, contact the

Center Director, USGS Geosciences and Environmental Change Science Center

Box 25046, Mail Stop 980

Denver, C0 80225

(303) 236-5344

Or visit the Geosciences and Environmental Change Science Center website at

https://www.usgs.gov/centers/gecsc 


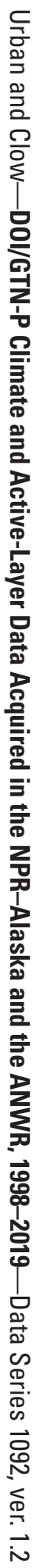

